\title{
Depth related brachiopod faunas from the lower Cambrian Forteau Formation of southern Labrador and western Newfoundland, Canada
}

\author{
C.B. Skovsted, I. Knight, U. Balthasar, and W.D. Boyce
}

\begin{abstract}
A diverse fauna of organophosphatic brachiopods is described from the late early Cambrian (Series 2, Stage 3-4) Forteau Formation of southern Labrador and western Newfoundland. The total fauna includes 11 species representing a wide selection of Cambrian brachiopod groups. Three distinct assemblages are recognized: Assemblages 1 and 2 are found in shallow water carbonates in association with archaeocyathans in southern Labrador and the western side of the Great Northern Peninsula of western Newfoundland. Assemblage 3 is found in a distal shelf setting of Gros Morne National Park. Assemblages 1 and 2 are found in stratigraphic continuity and define two brachiopod biozones, a lower Hadrotreta taconica zone and a higher Paterina zone, respectively. The presence of $H$. taconica in brachiopod Assemblage 3 possibly indicates time equivalence of Assemblage 1 but in a deep water setting. The identification of distinct time equivalent brachiopod Assemblages (1 and 3) in shallow and deep water environments of the Forteau Formation allow for the first time an analysis of environmental constraints determining the distribution of individual brachiopod taxa in the lower Cambrian succession of eastern Laurentia. Comparison to faunas from other areas indicates that the identified distributional patterns can be extended to other brachiopod faunas found along the Cambrian palaeocoast/margin of eastern Laurentia. The study indicates that specific brachiopod taxa can be used as indicators of palaeodepth; Botsfordia caelata in shallow environments and Eoobolus priscus and Eothele tubulus in deeper water. The following new taxa are described: Kyrshabaktella diabola n. sp., Pustulobolus triangulus n. gen et n. sp., Acrothyra bonnia n. sp.
\end{abstract}

C.B. Skovsted. Swedish Museum of Natural History, Department of Palaeobiology, SE-104 05 Stockholm, Sweden (corresponding author). christian.skovsted@nrm.se

I. Knight. Government of Newfoundland and Labrador, Department of Natural Resources, Geological Survey, P.O. Box 8700, St. John's, Newfoundland and Labrador, A1B 4J6. ianknight@gov.nl.ca U. Balthasar. School of Geography, Earth and Environmental Sciences, Plymouth University, Drake Circus,

http://zoobank.org/482B4F4C-E674-46BB-B4E7-2768C8E0D357

Skovsted, C.B., Knight, I., Balthasar, U., and Boyce, W.D. 2017. Depth related brachiopod faunas from the lower Cambrian Forteau Formation of southern Labrador and western Newfoundland, Canada. Palaeontologia Electronica 20.3.54A: 1-52. https://doi.org/ $10.26879 / 775$

palaeo-electronica.org/content/2017/2048-brachiopods-of-the-forteau-formation

Copyright: November 2017 Palaeontology Association.

This is an open access article distributed under the terms of Attribution-NonCommercial-ShareAlike 4.0 International (CC BY-NC-SA 4.0 ), which permits users to copy and redistribute the material in any medium or format, provided it is not used for commercial purposes and the original author and source are credited, with indications if any changes are made.

creativecommons.org/licenses/by-nc-sa/4.0/ 
Plymouth PL4 8AA, UK. uwe.balthasar@plymouth.ac.uk

W.D. Boyce. Government of Newfoundland and Labrador, Department of Natural Resources, Geological Survey, P.O. Box 8700, St. John's, Newfoundland and Labrador, A1B 4J6. dougboyce@gov.nl.ca

Keywords: Brachiopoda; Linguliformea; Cambrian; Palaeoecology; Biostratigraphy; Laurentia

Submission: 11 April 2017 Acceptance: 17 October 2017

\section{INTRODUCTION}

Brachiopods are among the most common and well-studied fossils in Cambrian rocks worldwide (Walcott, 1912; Williams et al., 1998; Ushatinskaya, 2008; Zhang et al., 2008). The first representatives appear in the Tommotian Stage of Siberia and Mongolia (Terrenuvian Series, Unnamed Stage 2; Skovsted et al., 2014b, 2015) and the brachiopod stem group (i.e. tommotiids; Skovsted et al., 2008, 2009, 2011, 2014a; Larsson et al., 2014) is known from even older strata of the Fortunian Stage (Maloof et al., 2010; Kouchinsky et al., 2012). Brachiopods diversified rapidly during the early Cambrian and most of the main Palaeozoic lineages (Class) had appeared by the middle Cambrian (Cambrian Series 3 ) by which time brachiopods were well represented in most benthic communities worldwide (Ushatinskaya, 2001).

Early Cambrian brachiopod faunas are typically diverse with morphologically distinct and geographically widespread taxa. On the generic level many taxa show a more or less global distribution, and several species are known to occur on different palaeocontinents (Brock et al., 2000; Skovsted and Holmer, 2005; Popov et al., 2015). This is particularly true for the organophosphatic brachiopods that represent about $50 \%$ of the total diversity in the early Cambrian and are easily extracted by standard acid preparation techniques. These characteristics would suggest that brachiopods, despite a tendency towards long stratigraphic ranges, hold a good potential for intercontinental correlation and biostratigraphic resolution in the Cambrian. Their utility for biostratigraphy and biogeography is hampered, however, because early Cambrian brachiopods remain poorly understood in terms of their ecology. Exceptionally preserved brachiopods exhibiting details of soft anatomy, in particular from the Chengjiang fauna of south China (Zhang et al., 2004, 2007, 2008, 2009, 2010, 2011) and the Burgess Shale (Holmer and Caron, 2006; Petterson Stolk et al., 2009; Topper et al., 2014, 2015) have recently yielded important insight into the autecology of early Cambrian brachiopods, but unfortu- nately the vast majority of described taxa have not been found in these exceptional faunas.

Herein, we describe a diverse brachiopod fauna from the Forteau Formation of southern Labrador and western Newfoundland. The Forteau Formation is richly fossiliferous and has been studied from the mid-nineteenth century onwards (Billings, 1861; Schuchert and Dunbar, 1934; Resser, 1937). However, little palaeontological work on the Forteau Formation has been published in the last 80 years, except for revisions of archaeocyathids (James and Debrenne, 1980; Debrenne and James, 1981) and the problematic fossil Salterella Billings, 1861 (Yochelson, 1977; Fritz and Yochelson, 1988; Skovsted, 2003). More recently, Butterfield and Harvey (2012) reported well- preserved assemblages of small carbonaceous microfossils from the formation and Skovsted and Peel (2007) published the description of a diverse fauna of Small Shelly Fossils from the argillaceous deepwater facies of the Forteau Formation in the Bonne Bay area of western Newfoundland. Although brachiopods were illustrated and briefly discussed in the latter paper, this component of the fauna was never fully described. Trilobite faunas are presently in review and being described (Boyce and Knight, in prep). Olenellid trilobites recovered from lower Hawke Bay Formation at Hawkes Bay, Canada Bay, and Bonne Bay indicate the Forteau lies entirely within the Bonnia-Olenellus biozone (Knight, 1991, 2013; Knight and Boyce, 1987; Knight et al., 2017).

In connection with a larger investigation of the entire shelly fauna of the Forteau Formation, new collections of brachiopods were recovered from the Forteau Formation at different localities in southern Labrador and western Newfoundland. These collections represent a range of different palaeoenvironments and form the basis of the present work. The total brachiopod fauna consists of at least 13 species, including eight lingulates, two paterinids, the problematic stem group linguliform Setatella significans Skovsted et al., 2010, and at least two species with calcareous shells. The two paterinid 
species will be described separately elsewhere and are only included here under open nomenclature (Paterina sp. and Micromitra sp.), while the two calcareous forms (Obolella sp. and Kutorgina sp.) are only rarely found in acid-macerated samples and will not be discussed further herein. The eight lingulate species are described in detail, in conjunction with an analysis of the assemblage composition of the organophosphatic brachiopod fauna of the Forteau Formation.

The presence of coeval rocks representing different sedimentological settings occurring in relatively close proximity to each other in the study area provide the means for placing brachiopods in a palaeo-depth transect through the Forteau Formation. This in turn provides new clues to the ecological preferences of individual brachiopod taxa. This type of information may be used to predict the distribution of brachiopod faunas and as a guide for future fieldwork and biostratigraphical and biogeographical analysis. The study reveals substantial differences in the faunas across depth-related facies, suggesting that early Cambrian brachiopods might be used to reconstruct palaeoenvironments similar to brachiopod faunas later in the Palaeozoic.

\section{MATERIAL AND METHODS}

Sampling was undertaken, beginning in 2007, with additional work in 2008, 2009, 2010, and 2011 , at a number of localities in southern Labrador and western Newfoundland (Figure 1). Sectioning and sampling of the formation in southern Labrador centered principally on Fox Cove and Point Amour on the coast, and roadcuts and quarries near Forteau, L'Anse-au-Loup, and Diablo Bay (Figures 2-3; Appendix 1). This essentially covered stratigraphy from the base of the formation to the lower part of the Upper limestone (see below for discussion of local stratigraphic divisions). A single spot sample from the boundary interval of the Devils Cove and Middle shale members at Forteau (F1) and a sample of loose limestone slabs collected close to Fox Cove (FCX) were also included in the investigation (Appendix 2).

In northwest Newfoundland, sectioning and sampling occurred over a wide geographic area of the Great Northern Peninsula (GNP; Figure 1). This included roadside outcrops and quarries near Mount St. Margaret (MSM), East Castor Pond (ECP), and Route $432(\mathrm{R})$ in the St Barbe area (Figures 4-6) and woods roads near Big East River northeast of Hawkes Bay (BER; Figures 4, 7). A drill core completed through the formation at Sav- age Cove (Straits shore of the GNP) in 2010 provides the full lithostratigraphy of the formation (Knight et al., 2017) and is used here to help stratigraphically place the scattered sections sampled on the GNP.

In Gros Morne National Park, sectioning and sampling principally used roadcuts along Route 430 as it skirts the coast of Deer Arm and East Arm of Bonne Bay (Figure 7). The sections in Bonne Bay were measured and collected in 2009 to 2011 (Figures 8-9; see Knight, 2013) following random sampling of several roadcuts in 2007 (see Appendix 1).

Detailed lithological sections were measured using a graduated metre stick, $1.5 \mathrm{~m}$ long divided into $10 \mathrm{~cm}$ intervals and samples collected for brachiopod analysis are located on the sections (Figures 3,5-9). The number of specimens of each brachiopod species found in the investigated samples is presented in Appendix 1.

In addition, material from collections made by A.R. Palmer with students in 1978 and 1979 from the same general area housed in the Institute for Cambrian Studies (previously in Boulder Colorado, now at University of Chicago, Michigan) was included in the investigation. This material comprises four samples collected from the Gros Morne National Park and one sample from the quarry at Mount St. Margaret of western Newfoundland in addition to 13 samples from southern Labrador. Brachiopod specimens were also derived from a limestone sample (sample JSP1982-01) collected by J.S. Peel in Gros Morne National Park which yielded the bulk of the Small Shelly Fossils documented by Skovsted and Peel (2007). Detailed locality information and faunal content of all additional samples are found in Appendix 2.

Fossiliferous limestone samples from all newly sampled sections were dissolved in 10\% buffered acetic acid at Uppsala University and the Swedish Museum of Natural History, and the resulting residues were scanned under binocular microscope for brachiopod specimens. All complete valves or large valve fragments with the posterior margin preserved were counted and selected specimens were coated in gold and imaged at the SEM facilities at Uppsala University and Swedish Museum of Natural History.

\section{GEOLOGICAL SETTING}

The Labrador Group (the definition of the group follows that of Schuchert and Dunbar, 1934) is the first sedimentary succession to be laid down in western Newfoundland as part of the Lower 


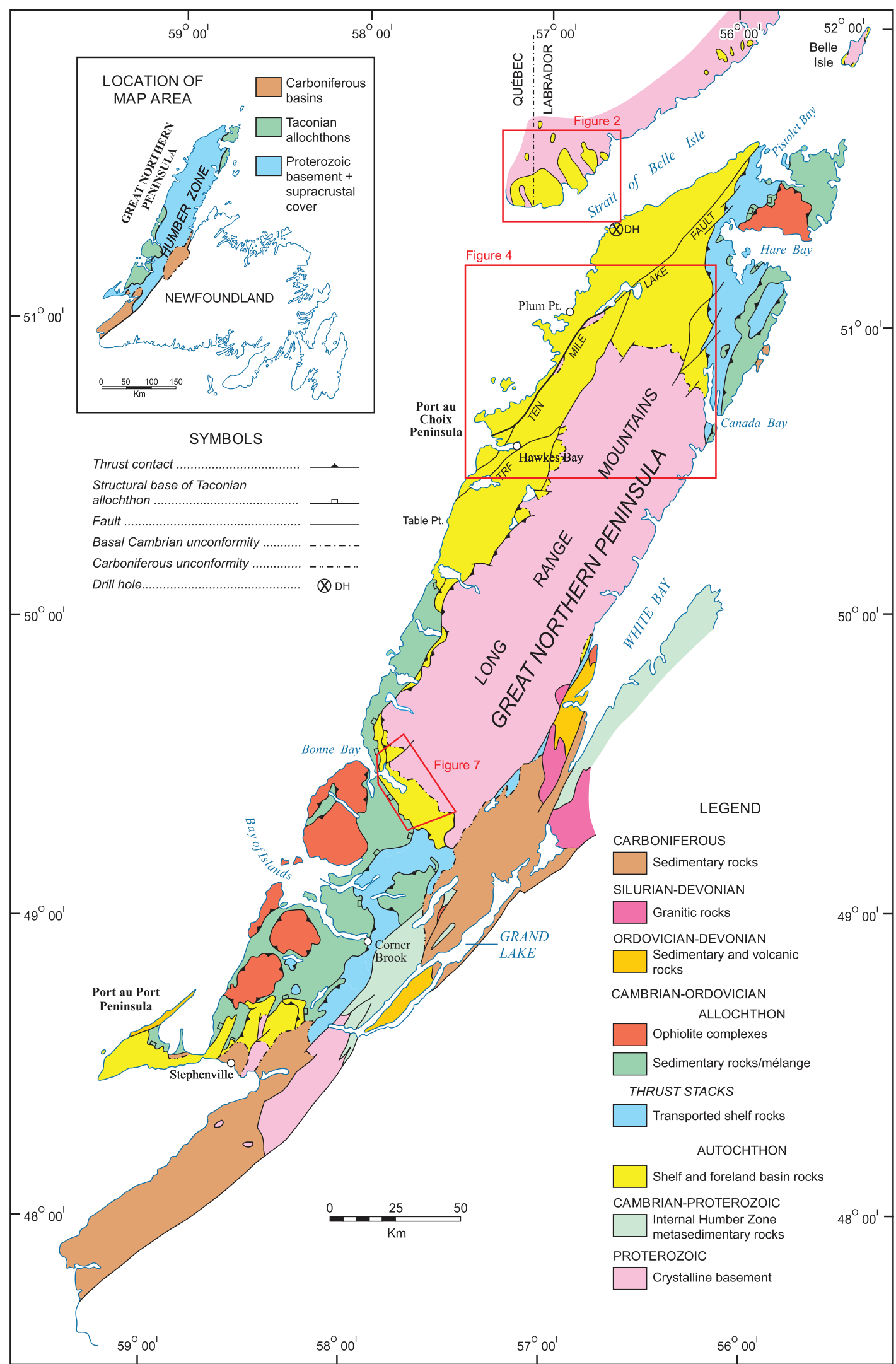

FIGURE 1. Geology map of western Newfoundland and southern Labrador showing main geological terranes and outlining the location of the study areas discussed in this article and illustrated in more detailed maps in Figures 2, 4, 7. 


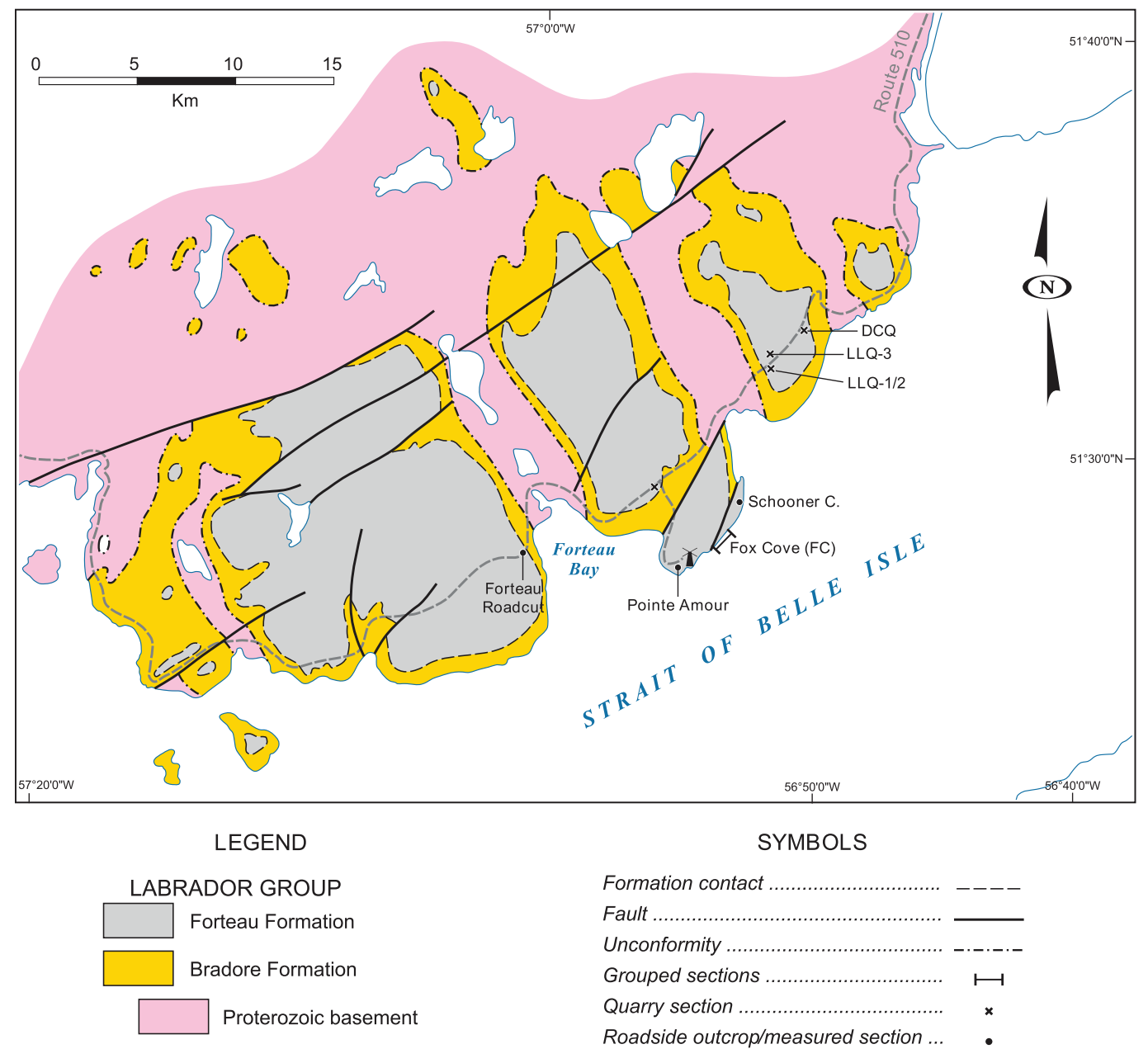

FIGURE 2. Geology map of the south coast of Labrador showing localities in the Forteau Formation, Labrador Group that were studied and yielded a rich brachiopod fauna (map based on Bostock et al., 1983 and Gower, 2010). LLQ L'Anse-au-Loup quarry, DCQ - Diablo Cove quarry

Paleozoic shelf that formed the southern paleomargin of Laurentia. It is now preserved in the outer Humber Zone (Williams, 1979; Hibbard et al., 2006) and the adjoining foreland to the Appalachian-Caledonian orogenic belt. In most parts of the Humber Zone, the group rests unconformably upon middle to late Proterozoic basement rocks. In southern Labrador and the western side of the Great Northern Peninsula, the group is gently dipping above the basement although cut by a series of northwest-verging, northeast-trending, highangle reverse faults that repeat the basement-shelf succession (Knight and Boyce, 2015; Knight et al., 2017). Elsewhere in western Newfoundland however, including the Bonne Bay area of Gros Morne National Park (GMNP), the group is strongly deformed as part of a complex foreland fold and thrust belt (Knight, 2007, 2013).
The Labrador Group (Schuchert and Dunbar, 1934) has a tripartite stratigraphy of Bradore, Forteau and Hawke Bay formations. The Forteau Formation comprises marine shale, siltstone, sandstone, and limestone and includes classic archeocyathid reef complexs (James and Kobluk, 1978; Hughes, 1979; Kobluk and James, 1979; James and Debrenne, 1980, Debrenne and James, 1981). It is sandwiched between red, fluvial to marginal marine sandstone of the Bradore Formation below (Hiscott et al., 1984; Long and Yip, 2009) and sequences, often coarsening upward, of shale, heterolithic fine-grained siliciclastics (sandstone, siltstone and shale) and pink and white quartz arenite of the Hawke Bay Formation above; the latter was laid down in a storm-dominated shoreface setting (Knight and Boyce, 2014). This succession has long been considered to preserve a third order sequence of onlap and offlap of the 


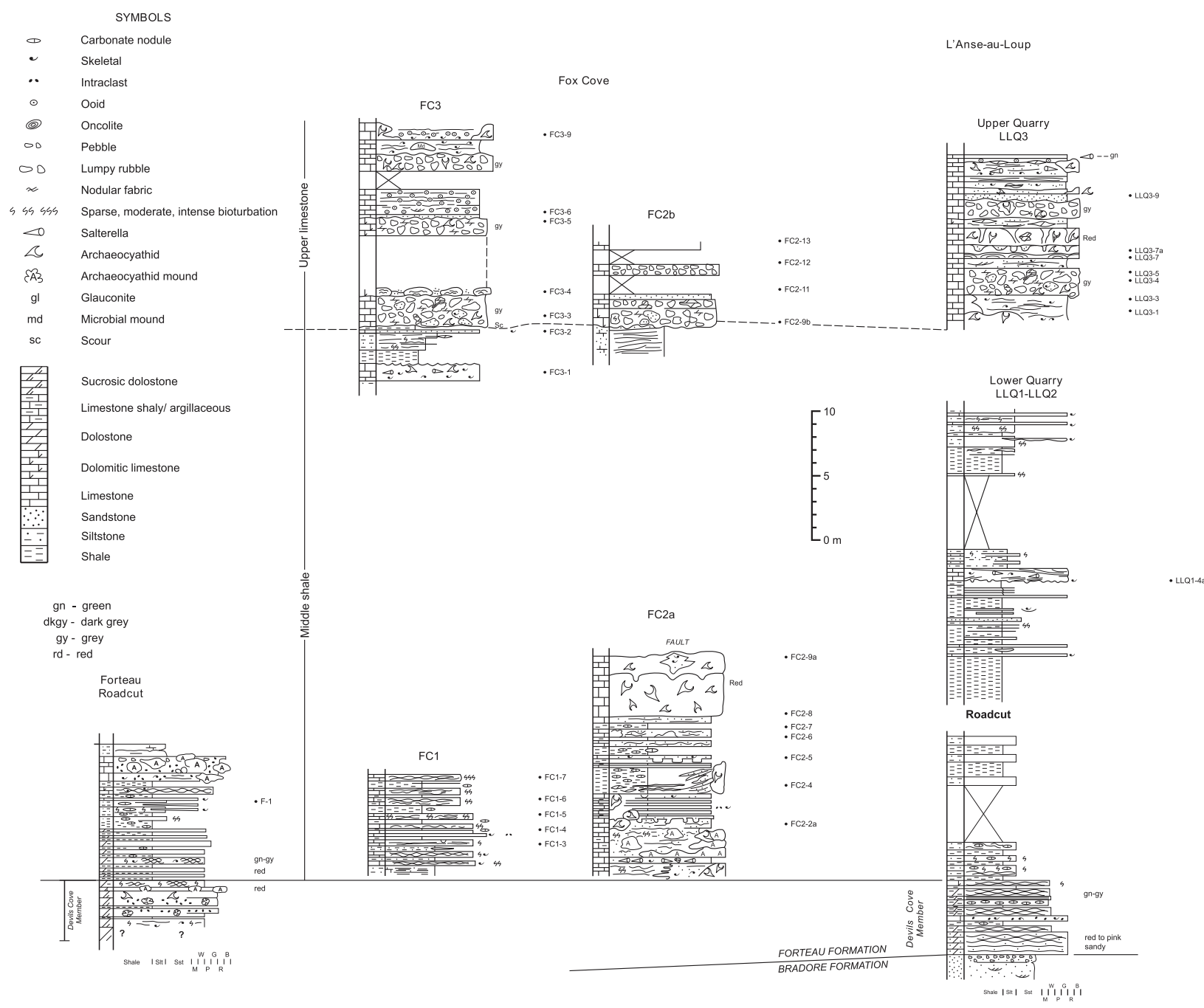

FIGURE 3. Sections measured in the Forteau Formation of south Labrador coast. FC1 (open shelf facies of James and Kobluk, 1978) and FC2a (Patch reef facies of James and Kobluk, 1978; bioherm of Debrenne and James, 1981) are adjacent to each other on the foreshore east of Fox Cove; FC2 is divided into a lower (FC2a) and upper part (FC2b) separated by a vertical fault that cuts out most of the Middle shale; FC3 is measured to the southwest of FC2 and is a composite of three short sections that are correlated over more than $50 \mathrm{~m}$ on the base of the Upper limestone (upper biostrome of Debrenne and James, 1981). Legend is applicable to all stratigraphic figures (Figures 5-6, 8-9).

margin during the late early to early middle Cambrian when the proto-shelf was interpreted to be an eastward deepening ramp (James et al., 1989).

Ongoing mapping and stratigraphic studies throughout western Newfoundland, however, show that there is considerable lithological complexity in the 3-part succession of the Labrador Group as it is traced from the well-known and studied, barely deformed autochthonous successions exposed in southern Labrador and western GNP to areas in the east and south where the deformed strata is parautochthonous to allochthonous. In particular the Forteau Formation changes radically as it is traced beyond its type area where the succession is considered to occupy a paleo inner shelf position on the margin (Knight, 2013; Knight et al., 2017). In contrast, successions such as those at Bonne Bay, Canada Bay, White Bay, and near Stephenville occupied deeper water paleo-outer shelf settings on the ancient shelf.

\section{Inner Shelf Succession}

The inner shelf succession of the Forteau Formation consists of three members; the Devils Cove, Middle shale and Upper limestone (Knight and Boyce, 2015; Knight, 2013; Knight et al., 2017). The members are readily identified in drill and quarry logs inland of the shores of the Strait of Belle Isle, GNP where it ranges up to $120 \mathrm{~m}$ in thickness (Lovering and Dunbar in Schuchert and 


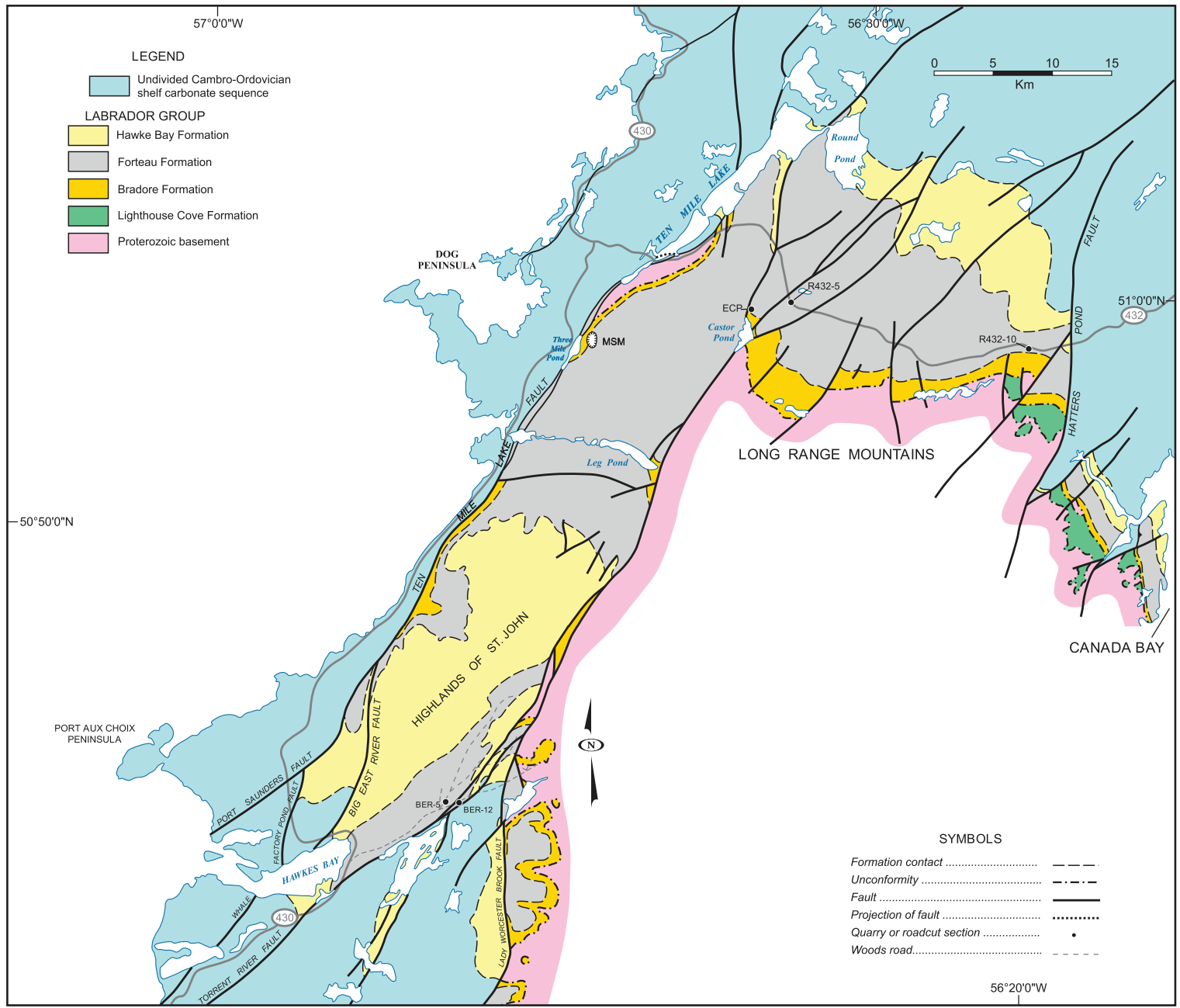

FIGURE 4. Geology map of central part of the Great Northern Peninsula showing faunally productive localities studied at Mount St. Margaret, along Route 432 north of the Long Range Proterozoic massif, and along the Big East River resource road at the south end of Highlands of St. John. MSM - Mount St. Margaret, ECP - East Castor Pond road, R432-5 etc - Route 432; BER-5 etc - Big East River resource road.

Dunbar, 1934 figure 8; Cumming in Bostock et al., 1983; Knight, unpublished data). Although incomplete in Labrador, the 56 to $70 \mathrm{~m}$ succession is still divisible into the three members (See figure 2 in James and Kobluk, 1978; Figure 3, this paper).

Devils Cove member. The informal Devils Cove member (Betz, 1939), a regionally mapped carbonate unit, 3 to $8 \mathrm{~m}$ thick, at the base of the formation, is characterized by its red to purple colour, nodular fabric with abundant shale partings and mix of grainy and fine-grained carbonate. Crossbedded, skeletal and intraclastic dolostone associated with metre-scale archeocyathid mounds occur locally in southern Labrador and the drill hole at Savage Cove; only scattered archeocyathans occur with other skeletal debris in grainstone at MSM and East Castor Pond (ECP). In southern Labrador and near the Highlands of St. John, the member is fully or partially dolomitized (Cumming in Bostock et al., 1983; Knight, 1991; this study). Small, dolomitized archeocyathid mounds mark the basal contact and abundant quartz sand is intermixed in the dolostone just east of Fox Cove. A few beds of red Bradore sandstone intercalate in the basal metres of the member at ECP. This suggests that the basal contact of the member with the Bradore Formation is sharp and conformable to locally transitional throughout the in-shore belt. The upper contact with the overlying middle shale member ranges from sharp (Fox Cove, L'Anse-au-Loup, Mount St. Margaret) to gradational (west of Forteau).

Middle shale. The Middle shale is characterized by a succession of grey to green-grey shale intercalated with nodular limestone, archaeocyathid reefs and their companion sediments, calcareous siltstone, and minor sandstone. The succession in 


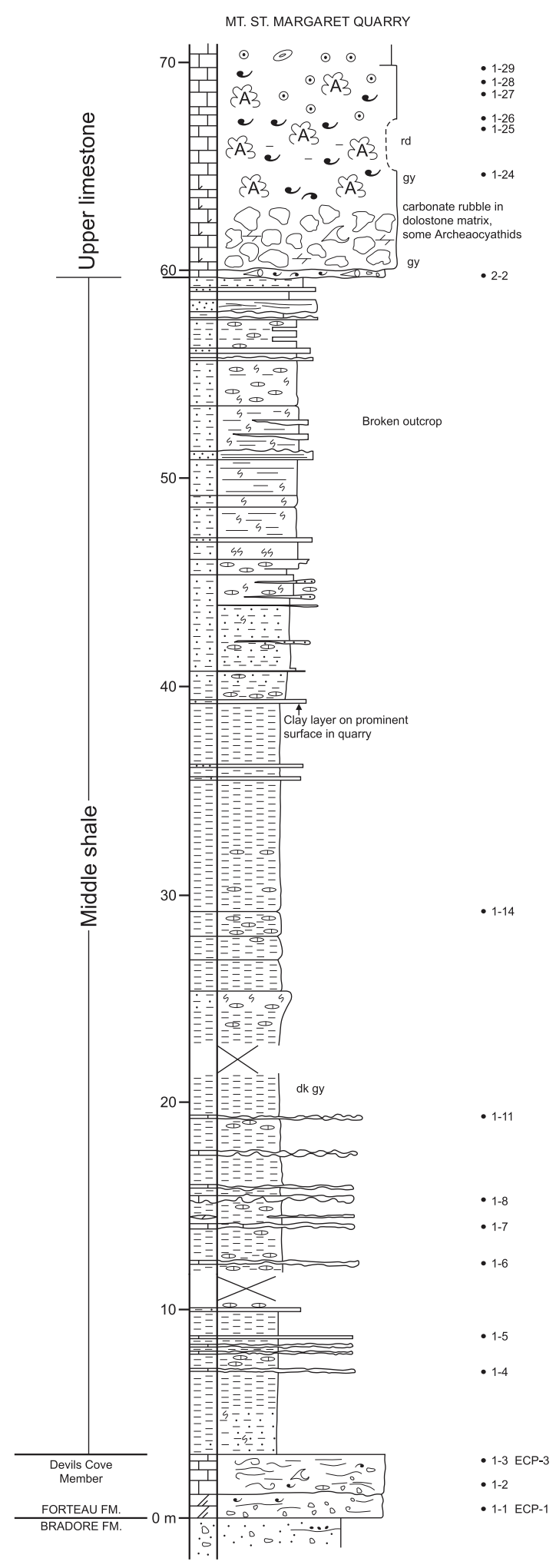

FIGURE 5. Stratigraphic section through the incomplete Forteau Formation exposed at Mount St. Margaret quarry (MSM). The archaeocyathid interval at top of section is partly based on scattered roadside outcrops above the quarry. The succession is host to brachiopod assemblage 1 and 2 . the member differs in detail from southern Labrador to the GNP.

In southern Labrador, a lower succession, about 15 to $20 \mathrm{~m}$ thick, of archeocyathid patch reefs, grey and red in colour, are associated with fringing grainstone and red and green, calcareous mudstone. The patch reefs pass laterally into an extensively developed, fine-grained open shelf succession of upward coarsening cycles of greengrey shale, nodular shaly calcareous siltstonelimestone, and calcareous siltstone-very-fine sandstone or silty limestone. The latter is generally extensively bioturbated; glauconite is noted in the succession (James and Kobluk, 1978; Hughes, 1979; James and Debrenne, 1980; Debrenne and James, 1981). The clustered patch reef bioherms at Fox Cove to Pointe Amour (see James and Kobluk, 1978 and Debrenne and James, 1981 for full description of the distribution and complexity of these sequences) are adjacent to co-eval sections of the open shelf facies such as near Schooner Cove and L'Anse-au-Loup.

Grey to green-grey shale, 15 to $20 \mathrm{~m}$ thick, traced from Pointe Amour northeast to the lower quarry east of L'Anse-au-Loup, marks the upper part of the member. The shale hosts olenellid trilobites and is intercalated upward with skeletal and intraclastic grainstone storm beds that exhibit traces of opportunistic burrowers. Mudrock and calcareous siltstone with skeletal limestone and some fine-grained HCS sandstone are increasingly important near the top of the middle shale.

In the northwest of the GNP, the member is represented by a $40 \mathrm{~m}$ thick succession that gradually coarsens upward. Grey shale with some thin to medium beds of nodular to lumpy limestone of skeletal lime mudstone to packstone mark the basal part of the member. Salterella, trilobites, hyolithids, and other bioclasts occur. A middle interval of largely limestone-free shale occurs about 15 to $20 \mathrm{~m}$ above the base. Olenellids are common in the lower to middle shale interval. Upward, the shale gives way to siltstone that is host to limestone nodules and interbeds of intensely bioturbated siltstone and very fine sandstone that near the top of the member display HCS.

The member has been logged in drill core at Savage Cove (Knight et al., 2017), and in quarries at MSM, along Route 432 and near Big East River (BER 12). Slump folds and slides deform the shale that is host to horizons of limestone nodules and large carbonate concretions at BER 12.

Upper limestone. The incomplete Upper limestone in southern Labrador is host to a basal bios- 
PALAEO-ELECTRONICA.ORG
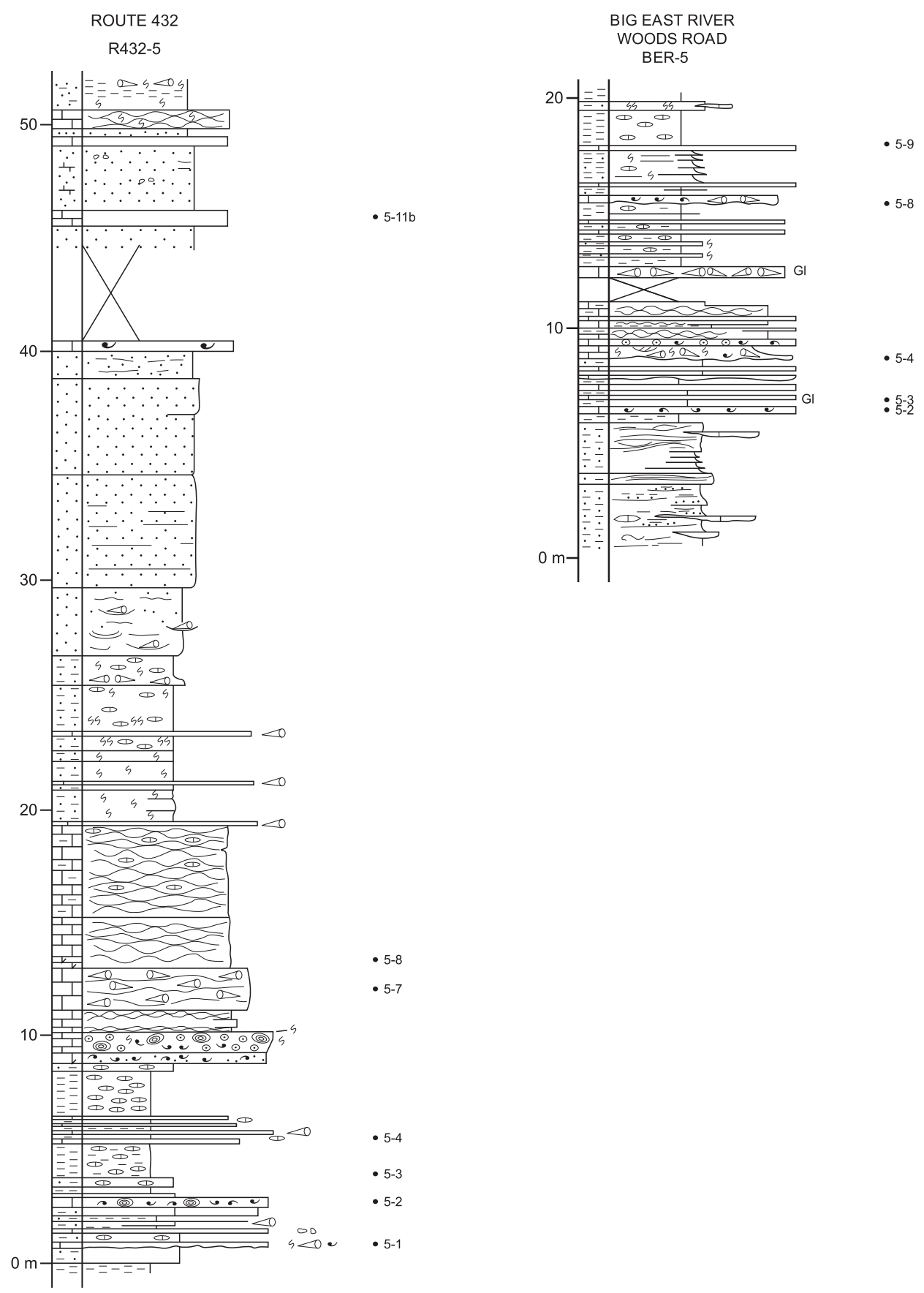

FIGURE 6. Measured sections displaying samples collected from rocks of the upper heterolithic interval of the Upper limestone, Forteau Formation on Route 432 east of Ten Mile Lake (R432-5) and Big East River resource road northeast of Hawkes Bay (BER-5) (see Figure 4). Both sections host brachiopod assemblage 2. The succession at R432-5 comprises skeletal carbonate and shale overlain by calcareous siltstone and white quartz arenite. The incomplete succession at BER-5 is lithologically similar to the lower carbonate interval of R432-5 and may tentatively suggest they are distant correlatives of the same parasequence. The brachiopod fauna hosted by lithofacies of small-scale transgression are inherited from the restricted fauna associated with the long-term regressive phase of the Forteau shelf sedimentation. 


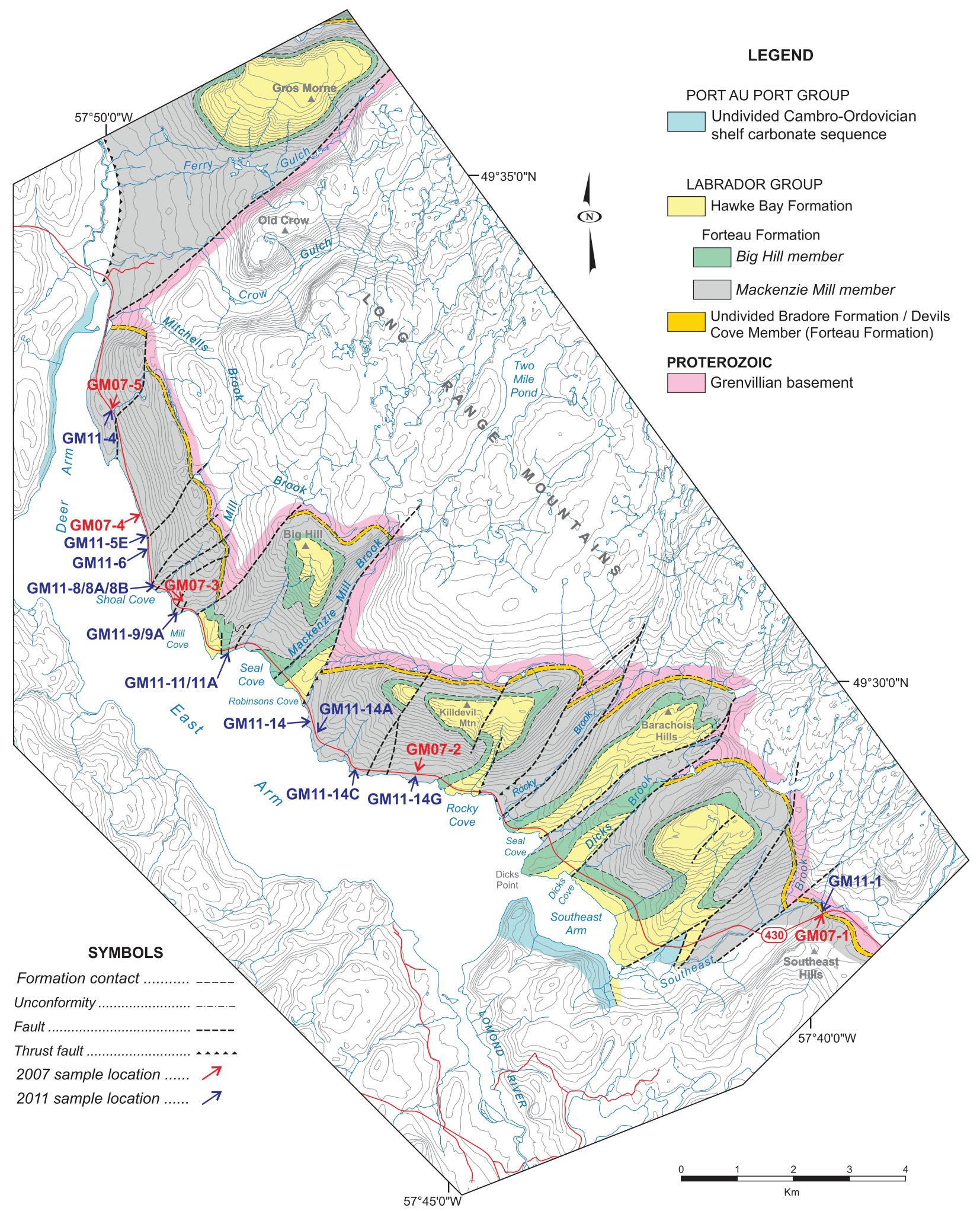

FIGURE 7. Geology map of the Gros Morne area showing location of sections in the Forteau Formation (based on Knight, 2013, figure 3). Samples GM07 -1 etc. were collected randomly in 2007 and are linked to localities GM11-1 etc. that were mapped, sectioned, and sampled in 2011 (see Figures 8-9). 


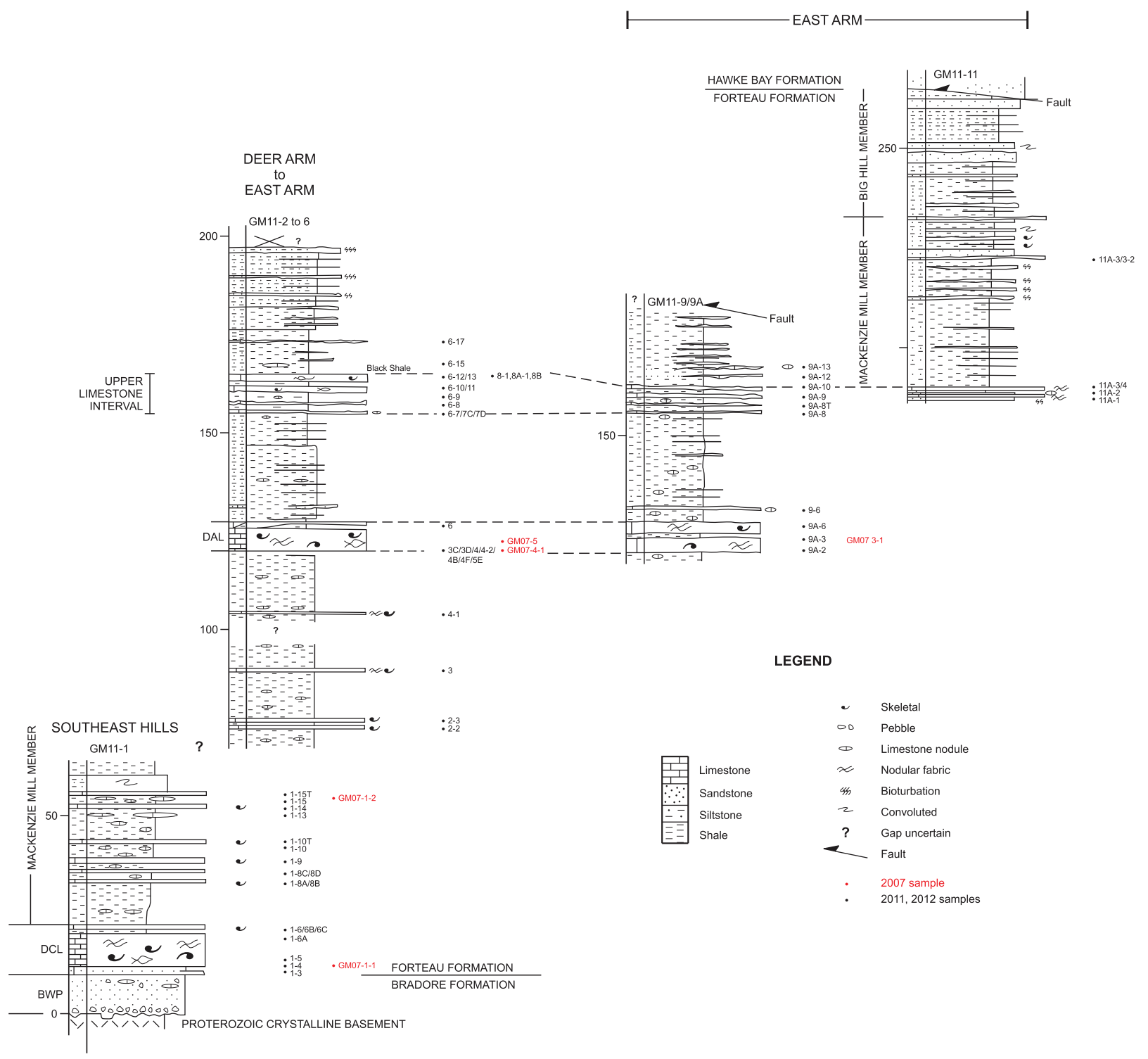

FIGURE 8. Stratigraphic sections through the Forteau Formation in Gros Morne National Park (based on Knight, 2013, figure 4) showing the correlation of limestone intervals and samples that yielded assemblage 3 brachiopod fauna. DAL - Deer Arm Limestone. DCL - Devils Cove limestone.

trome complex of archeocyathids, skeletal grainstone, bedded mudstone, and dolostone (James and Kobluk, 1987; Hughes, 1979). Upward, the complex interbeds with or is locally sharply overlain by oolitic limestone; microbial boundstone also occurs. The biostrome complex is well exposed in the upper quarry at L'Anse-auLoup. Nonetheless, parasequences of the open shelf facies (likely top of the Middle shale) capped by beds of skeletal, oolitic, and oncolitic limestone occur in the area of Diablo Bay and locally west of Forteau.
Much of the biostromal interval in southern Labrador, however, is rubbly in texture (Knight et al., 2017, this study), the rubble includes a range of limestone clasts from grainstone to lime mudstone to clustered and scattered archeocyathid debris set in a matrix of fine argillaceous, dolomitic carbonate. At Fox Cove and Pointe Amour, its base downcuts into underlying bedded siliciclastics and grainstone. Beds of archeocyathan mounds and skeletal grainstone overlie the rubble beds and locally intercalate with oolitic grainstone just below the top of the biostrome. At Pointe Amour the top of the biostrome sequence is truncated by a planar 


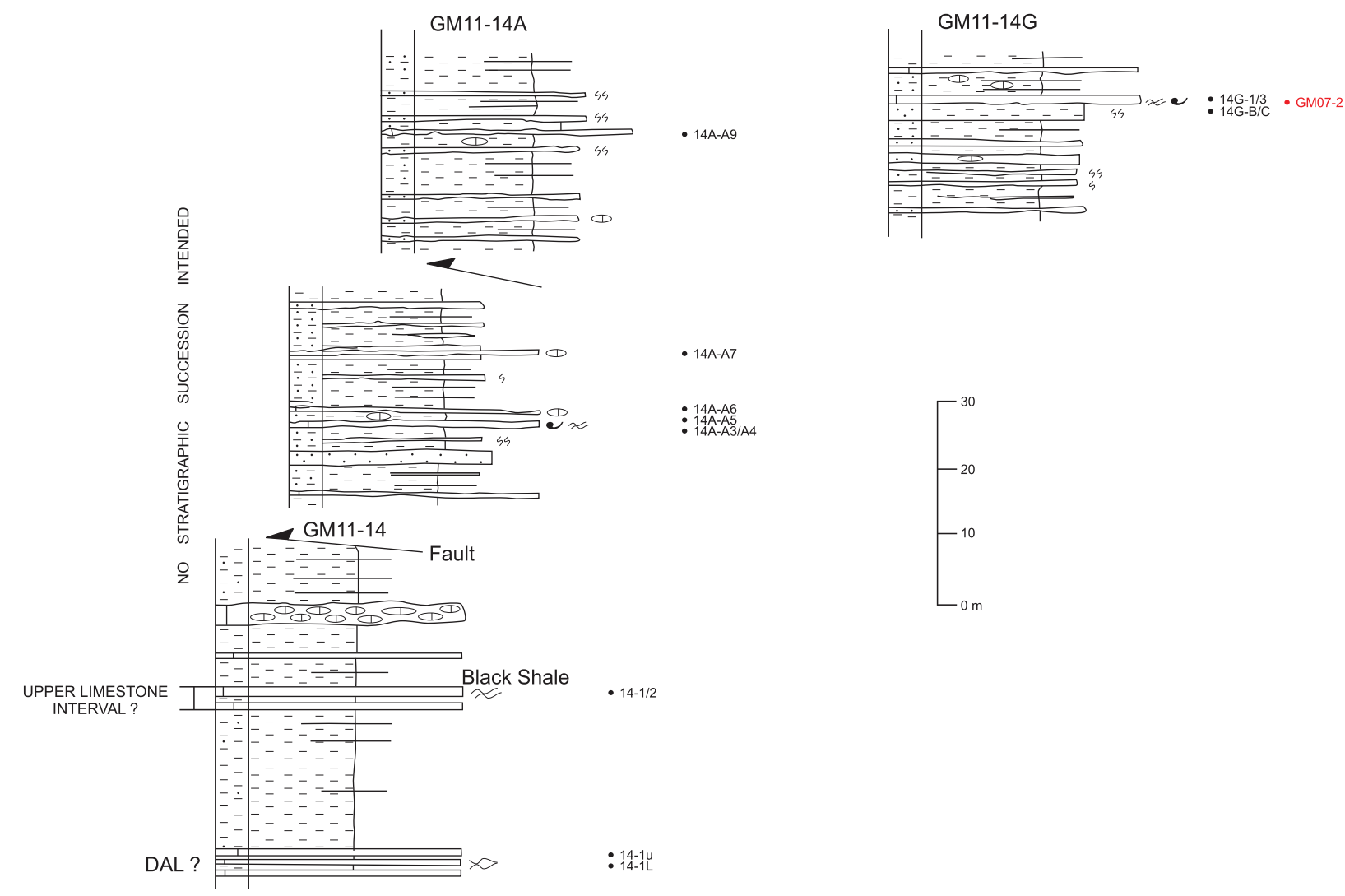

FIGURE 9. Sections for localities GM11-14, 14A and $14 \mathrm{G}$ at the eastern end of East Arm (see Figure 7) showing location of samples that yielded assemblage 3 brachiopod fauna. The folded and faulted succession there is difficult to correlate with any certainty to the stratigraphy of Figure 8. Nonetheless, two limestone intervals in GM11-14 are tentatively correlated with the Deer Arm (DAL) and Upper limestone interval of Figure 8. The offset of sections (GM11-14 and 14A) reflects the stratigraphic uncertainty of the structurally displaced succession although GM11-14G may correlate with the upper GM11-14A section.

scour overlain by oolitic grainstone; mounds of microbial boundstone also occur locally.

On the GNP, the upper limestone is 65 to 70 $\mathrm{m}$ thick (drill holes on the Straits shore, Knight et al., 2017, figure 2). It consists of a lower division comprised of archeocyathid bioherms and grainstone and an upper heterolithic division predominantly of carbonate with some metre-thick siliciclastic intervals. The lower division begins with a lower $7 \mathrm{~m}$ interval of archeocyathid bioherms, grainstone and lesser microbial boundstone. It is succeeded by about $18 \mathrm{~m}$ of oolitic, skeletal and Salterella-rich grainstone in which are scattered a few archeocyathans and broken oncoliths. Beds of matrix supported carbonate rudstone (matrix of shale, mudstone, or dolostone) occur in the lower interval and mark its base at MSM. Archeocyathid bioherms associated with skeletal and cross bedded, oolitic grainstone-filled channels occur on Route 463, MSM and near East Castor Pond
(Knight and Boyce, 2015) and can be traced southwest $60+\mathrm{km}$ to near Hawkes Bay (Knight et al., 2017). The bioherms are locally truncated below the overlying oolite unit.

The upper heterolithic division is a succession dominated by decametre-thick limestone intercalated with a few metre-thick intervals of siliciclastic rocks (Knight, unpublished drill hole log; Knight et al., 2017). The carbonate intervals consist of shale, thin bedded, nodular and bioturbated lime mudstone with skeletal lenses, and skeletal and ooliticoncolitic grainstone, some of which are arranged in metre-scale, coarsening upward parasequences. The siliciclastic intervals consisting of siltstone to fine sandstone and also including quartz arenites are important parts of the uppermost stratigraphy of the formation in the Hawkes Bay, BER, and Route 432 area (Knight, 1991; Knight et al, 2017; R432-5, Figure 7, this study). Outcrops along Route 463 and BER resource road mostly belong 
to the upper heterolithic interval. A dolostone locally after oolitic oncolitic grainstone and locally host to cement occluded fenestral fabrics mark the top of the limestone succession toward the top of the member in the drill holes at Savage Cove (Knight et al., 2017; see also Ham et al. in Bostock et al., 1983). The dolostone is probably laterally equivalent of the fabled "button-algae" bed of Schuchert and Dunbar (1934) that outcrops in the Hawkes Bay area toward the top of the member.

\section{Outer Shelf Succession}

The Forteau shelf succession in eastern areas of western Newfoundland comprises a thick succession of deformed mudrocks intercalated with siltstone, sandstone and lesser limestone, the deposits of a deeper water, outer ramp. It is about $230 \mathrm{~m}$ thick at Bonne Bay where the succession is divided into the Devils Cove, Mackenzie Mill, and Big Hill members (Figures 7-9; Knight, 2013).

Devils Cove member. At Gros Morne, the member consists of $12.3 \mathrm{~m}$ of pink, off-white, greenishwhite to grey, impure limestone interbedded with purple sandstone beds and partings in the lower half and a few shale beds near the top of the member. The stratified to nodular limestone includes skeletal-rich lime mudstone-wackestone, some grainstone, lenses of skeletal packstone/grainstone, and rare skeletal limestone-coquina of thinshelled skeletal debris. The basal contact with the underlying Bradore Formation is conformable and likely diachronous (James et al., 1988; Knight, 2013, this study); the upper contact is sharp at GMNP but gradational at Canada Bay and near Stephenville. Trilobites, Salterella, and solitary archeocyathids, the latter identified as the regularis species A., occur in the member in GMNP (James and Stevens, 1982; James et al., 1988; James and Debrenne, 1980).

Mackenzie Mill member. The Mackenzie Mill member consists of 190 to $210 \mathrm{~m}$ of well-lithified, calcareous mud rock, black and dark grey shale and mudstone, calcareous thin bedded siltstone and sandstone, current bedded and bioturbated sandstone, and nodular to lumpy, fine grained to skeletal-rich limestone. A prominent fossiliferous dark grey limestone marker, the Deer Arm limestone (DAL) occurs midway through the member and an upper limestone interval $30 \mathrm{~m}$ higher (Figures 8-9; James et al., 1988; Knight, 2013). The succession is divided into five informal stratigraphic intervals (Knight, 2013) as follows:
1) a lower interval, $95 \mathrm{~m}$ thick, of mudrock rich in lime mudstone nodule horizons and some skeletal, nodular limestone interbeds. The mudrock is generally thinly stratified and finely laminated. Nodular limestone in this interval has yielded elements of the fauna described by Skovsted and Peel (2007);

2) the Deer Arm limestone (DAL), 3.5 to $9 \mathrm{~m}$ thick, consists of nodular to lumpy, dark grey, locally shaly and dolomitic, fossiliferous fine grained limestone with some intercalated black shale. The limestone is rich in Salterella and trilobites, and also hosts scattered brachiopods and minor molluscs; it yields much of the SSF described from the Forteau Formation in Bonne Bay (Skovsted and Peel, 2007);

3) a middle interval, 22 to 29 m thick, of mudrock intercalated with ribbon siltstone and burrowed sandstone; slump beds and sandstone dykes occur locally;

4) an upper limestone interval, 2.5 to $11 \mathrm{~m}$ thick (the interval thins to the southeast) that consists of a lower nodular and phosphatic sandy dolostone intercalated, with intensely bioturbated siltstone and sandstone below three beds of dark grey, nodular fine-grained skeletal limestone intercalated with black to dark grey shale rich in limestone nodules; a thin, oolitic, and oncolitic limestone cap marks the lowest and thinnest of the three beds; and

5) an uppermost heterolithic interval, at least 45 to perhaps $70 \mathrm{~m}$ thick, of ribbon siltstone-sandstone and shale, thin bedded and massive mudrock, bioturbated sandstone dominated by Rossellia, cross bedded sandstone, rare quartz-rich sandstone, and, several thin, dark grey limestone beds of mostly unidentifiable trilobite debris. Decimeter to metre-scale, coarsening-upward cycles of mudrock, ribbon bedded siltstone capped by bioturbated sandstone are common. Pot and gutter casts and slump breccia occur just below the top of the member.

Big Hill member. The Big Hill member is a succession, about $30 \mathrm{~m}$ thick, of rusty- to dark-brown weathering, fine grained sandstone intercalated with dark grey mudstone and siltstone and khakiweathering mudrock and ribbon bedded siltstone. Pot and gutter casts occur low in the member, HCS in quartz arenite near the top. The member is conformable upon the Mackenzie Mill member and sharply overlain by the Hawke Bay Formation. Skeletal remains are very rare. 


\section{Sequence Stratigraphy}

Interpretation of the formation's sequence suggests that the inshore succession supports the onlap-offlap pre-shelf cycle of James et al. (1989). The transgressive system tract of the 3rd order sequence includes the top of the Bradore Formation, the Devils Cove member, and the lower 15 to $35 \mathrm{~m}$ of the Middle shale. Archeocyathid patch reefs form an important element of the open shelf during flooding of the margin. Their presently known distribution in the lower strata of the formation suggests they likely migrated diachronously as they spread inshore from the Devils Cove member at the north coast of the GNP (drill hole NF-1B amongst others, Knight et al., 2017) to the basal strata of the Middle shale in southern Labrador; in northwest GNP only mudrocks host to beds of fossiliferous fine dark grey limestone accumulated. In spite of the world renowned reef bodies in southern Labrador, the co-eval fine grained, open shelf facies (James and Kobluk, 1978; see also other related publications) is the predominant depositional motif of the TST as a whole. This suggests an open shelf, perhaps largely below a muted storm wave base and likely demands rapid transgression and shelf deepening along the Newfoundland margin (Knight et al., 2017).

The maximum flooding surface likely coincides with the shale-dominated interval exposed at LLQ-1 quarry and near Pointe Amour in southern Labrador (Figure 3) and the interbed-free shale 20 to $30 \mathrm{~m}$ above the base of the formation at MSM (Figure 5). The MFS is also likely located within a thick shale section at BER-12 quarry, northeast of Hawkes Bay (Figure 4), where slump folds and sedimentary slide surfaces imply shelf instability in this area. Shale giving way upward to burrowed siltstone and HCS sandstone at MSM (Figure 5) indicate that the shelf shallowed in the upper part of the shale member implying initiation of the highstand system tract (HST) that lead to a prograding, carbonate shelf (Upper limestone).

The succession in the Upper limestone suggests a high-energy barrier shoal complex that built close to sea level and marked the inner shelf. The complex advanced from southern Labrador to southeast of MSM but far short of Canada Bay and gave way southeastward to deeper shelf mudrockdominated deposition supporting an inner ramp to outer ramp transition (Knight et al., 2017). The archeocyathid biostromal complex of southern Labrador (James and Kobluk, 1978; Hughes, 1979) and archeocyathid bioherms with interreef channel-bound grainstone in western GNP (Knight and Boyce, 2015) support a significant but broken reefal tract associated with oolitic-skeletal grainstone shoals that formed the oceanward edge of the prograding inner ramp. It prograded close to the present western faulted edge of the Long Range Mountains from Hawkes Bay to east of Ten Mile Lake, its oceanward edge trending north northeast. The presence of polymictic rubbly beds, essentially carbonate conglomerate-breccia, may imply fore-reef talus locally along the frontal edge of the prograding shelf buildups or widespread inplace disintegration of parts of the reefal complex. The presence of upward coarsening sequences of shale, nodular limestone, and skeletal to ooliticoncolitic grainstone intercalated with intervals of siltstone to sandstone and beds of quartz arenite in the remaining member supports repeated prograding shelf accretion in the later stages of the formation. Like the reef-oolite shoal complex earlier in the HST, however, it is reasonable to conclude that the capping grainstone shoals of these parasequences also were limited geographically to the middle reaches of the GNP because only one oolite grainstone in the uppermost part of the formation reached Canada Bay (Knight and Boyce, 1987). The presence of clastic intervals in the upper part of the member indicates increasing encroachment of high-energy sand complexes along the landward edge of the Forteau carbonate shelf, a prelude to the deposition of the Hawke Bay Formation.

The correlation of the deeper water, outer shelf rocks of Gros Morne and adjacent areas such as Canada Bay with the simple on-lap off-lap sequence projected for the inner shelf is problematic however. The significantly thicker, predominantly fine-grained siliciclastic succession in GMNP is considered to be a major depo-centre at the time of the Forteau margin (Knight, 2013). Nevertheless, the Bradore Formation, Devils Cove member, and lower part of interval 1 of the Mackenzie Mill member likely reflects rapid transgression of the foundering Laurentian margin in this area, implying correlation with the TST of the inboard shelf. In addition, the upper part of the succession in GMNP indicates that the uppermost part of the Mackenzie Mill (interval 5) and Big Hill members show the shelf gradually shallowed into the storm zone.

Trilobites sampled throughout the study area are presently being investigated and their systematics, regional distribution, and stratigraphic ranges formally documented; this study also incorporates data of Walcott (in Schuchert and Dunbar, 
1934), Betz (1939), and Palmer (1969). The trilobite faunas provide sufficient evidence to allow correlation of the inner shelf and the deeper water Gros Morne succession as several of the most common species occur throughout southern Labrador and western Newfoundland across the range of paleo environmental settings discussed above.

The trilobites Bonnia parvula (Billings, 1861), B. senecta (Billings, 1861), and Calodiscus lobatus (Hall, 1847) all range throughout the incomplete Forteau Formation in southern Labrador (Devils Cove member to the Upper limestone). In the GNP sections $C$. lobatus ranges throughout the formation while $B$. parvula was found in the Middle shale and Upper limestone and $B$. senecta in the Upper limestone. In GMNP, C. lobatus, B. parvula, and B. senecta all occur in the lower part of the Mackenzie Mill member up to and including the DAL. Olenellus thompsoni (Hall, 1859) and O. transitans (Walcott, 1910) were found in the Middle shale and Upper limestone of both southern Labrador and GNP sections, as well as in the upper part of the Mackenzie Mill member (above the DAL). Wanneria walcottana (Wanner, 1901) was not found in southern Labrador but does occur in both the Upper limestone of GNP and in the Mackenzie Mill member above the DAL in GMNP. In addition, Elliptocephala logani (Walcott, 1910) occurs throughout the formation in all the sampled areas.

Limestone markers (DAL and Upper limestone interval) in the GMNP succession imply times of significant change in shelf dynamics from those that controlled the deposition of the thick, overwhelmingly fine-grained siliciclastic strata of the Gros Morne depocentre. This perhaps suggests two, perhaps three, thick sedimentary packages occur in this depo-centre. Knight (2013) searching for possible explanations suggested climatic change, sea level change, switching or cutoff of the fluvial input source or combinations of all three to explain carbonate deposition in the deeper water outer shelf setting.

\section{THE BRACHIOPOD FAUNA OF THE FORTEAU FORMATION}

The brachiopod collections from the Forteau Formation of Labrador and western Newfoundland contain at least 13 species, including 11 taxa with organophosphatic shells. The fauna is dominated by species with a wide distribution along the early Cambrian shelf of eastern Laurentia (Eoobolus priscus (Poulsen, 1932), Botsfordia caelata (Hall, 1847), Eothele tubulus Ushatinskaya in Voronova et al., 1987, Hadrotreta taconica (Walcott, 1887),
Setatella significans, and probably Micromitra sp. and Paterina sp.), but also includes new, apparently endemic, taxa (Kyrshabaktella diabola sp. nov., Pustulobolus triangulus gen. et sp. nov., Acrothyra bonnia sp. nov., Hadrotreta sp.). The new faunal list represents a significant increase in diversity relative to previous studies of the formation. Schuchert and Dunbar (1934, p. 19) listed two phosphatic-shelled species from southern Labrador previously identified by Walcott in 1910 as Micromitra (Paterina) bella (Billings, 1861) and Micromitra (Paterina) labradorica (Billings, 1861) in addition to four species with calcareous shells. Spencer (1980) reported two additional lingulate species (Lingulella (Lingulepis) cf. prisca Poulsen, 1932 and Hadrotreta primaeva Walcott, 1912; here reinterpreted as Pustulobolus triangulus and Hadrotreta taconica, respectively, from the same area.

\section{Facies Dependence of Brachiopod Assemblages}

Despite the wide geographical distribution in eastern Laurentia of many of the brachiopods found in the Forteau Formation, assemblages recovered from localities representing different facies of the formation differ dramatically in composition (Table 1). A subset of the recovered species are found across the entire width of the shelf (Hadrotreta taconica, Micromitra sp.), but other species appear to be restricted to either distal outer shelf or inner shelf settings, the latter divided between those faunas linked with the deepening phase of the transgressive systems tract (Botsfordia, Kyrshabaktella, Pustulobolus) and those that inhabited the high energy settings of the subsequent, regressive high stand system tract (Paterina). In particular, the absence of what appears to be inboard taxa (such as Botsfordia, Kyrshabaktella, Pustulobolus and Paterina) in the argillaceous facies of the distal shelf seems to suggest that the observed distributional pattern is controlled by intrinsic biological factors.

Calcareous brachiopods, including both kutorginids and obolellids, occur in relatively large numbers in the shallow water transgressive inboard facies of the Forteau Formation in southern Labrador. However, these taxa were mainly found in outcrop and not in acid-resistant residues, and their taxonomy or stratigraphical distribution has not been analyzed. Rare phosphatized specimens of Obolella sp. from the argillaceous facies of the lower intervals of the formation in the Bonne Bay area (Skovsted and Peel, 2007) have not been 
TABLE 1. Brachiopod assemblages of the Forteau Formation of southern Labrador and western Newfoundland, Canada with the presence of each taxon and assemblage in investigated stratigraphical sections indicated.

\begin{tabular}{|c|c|c|c|c|c|c|c|c|c|c|c|c|c|}
\hline \multirow{3}{*}{ Brachiopod taxa studied } & \multicolumn{12}{|c|}{ Sampled sections } & \multirow{3}{*}{ 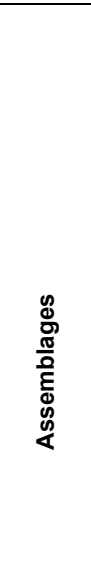 } \\
\hline & $\begin{array}{l}\frac{0}{0} \\
\frac{\pi}{5} \\
\frac{0}{0} \\
\frac{0}{0} \\
\sum \\
0 \\
0 \\
0 \\
0 \\
0 \\
0\end{array}$ & 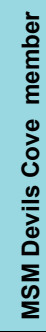 & $\begin{array}{l}\frac{0}{10} \\
\frac{5}{\omega} \\
\frac{0}{\overline{0}} \\
\frac{0}{\Sigma} \\
\sum \\
\Sigma\end{array}$ & 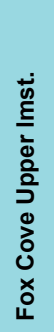 & 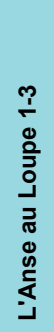 & 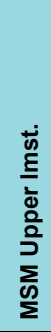 & 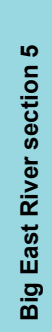 & 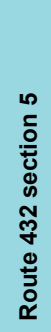 & 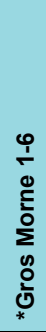 & 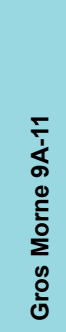 & 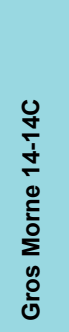 & 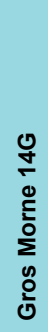 & \\
\hline & \multicolumn{3}{|c|}{$\begin{array}{c}\text { Inner shelf, } \\
\text { Transgressive } \\
\text { Stage }\end{array}$} & \multicolumn{5}{|c|}{$\begin{array}{c}\text { Inner shelf, Regressive } \\
\text { Stage }\end{array}$} & \multicolumn{4}{|c|}{ Outer shelf } & \\
\hline Micromitra sp. & $\bar{x}$ & & $\mathrm{x}$ & $x$ & $x$ & $\bar{x}$ & $\mathrm{x}$ & $x$ & $\mathrm{x}$ & $x$ & $x$ & $x$ & $1,2,3$ \\
\hline Hadrotreta taconica & $x$ & $x$ & $x$ & & & & & & $x$ & $x$ & $x$ & $x$ & 1,3 \\
\hline Eothele tubulus & & & & & & & & & $x$ & $x$ & $x$ & $x$ & 3 \\
\hline Eoobolus priscus & & & & & & & & & $x$ & $x$ & $x$ & $x$ & \\
\hline Acrothyra bonnia & & & & & & & & & $x$ & $x$ & & $x$ & \\
\hline Paterina sp. & & & & $x$ & $x$ & $x$ & $x$ & $x$ & & & & & 2 \\
\hline Setatella significans & & & & & $x$ & & $x$ & $x$ & & & & & \\
\hline Botsfordia caelata & $x$ & $\bar{x}$ & & & & & & & & & & & 1 \\
\hline Kyrshabaktella diabola & $x$ & $\mathrm{x}$ & $x$ & & & & & & & & & & \\
\hline Pustulobolus triangulus & $?$ & & $x$ & & & & & & & & & & \\
\hline Hadrotreta sp. & $x$ & $x$ & & & & & & & & & & & \\
\hline
\end{tabular}

*) excludes the Devils Cove member

analyzed further due to the strong taphonomic control of the distribution of calcareous shells compared to originally phosphatic shells in acid resistant residues.

\section{Inner-shelf Fauna}

The inner shelf of the Forteau Formation preserved in southern Labrador and the western side of the Great Northern Peninsula (GNP) is host to two brachiopod faunas (Table 1). The lower fauna (faunal assemblage 1) thrived during middle Dyeran flooding of the late early Cambrian shelf that stratigraphically comprises the Devils Cove member and the lower part of the Middle shale. Then, the shelf, principally in southern Labrador but likely extending to the coastline of the GNP, was marked by archaeocyathid patch reefs scattered across an open shelf where fine-grained bioclastic limestone, calcareous siltstone, and shale were deposited in interreef and open shelf settings
(James and Kobluk, 1978). All facies are rich in brachiopods that form a diverse assemblage in the Devils Cove member (Hadrotreta, Kyrshabaktella, Botsfordia, Micromitra) at Mount St. Margaret and East Castor Pond and in the lower patch reef complex of southern Labrador (Botsfordia, Kyrshabaktella, Hadrotreta, Micromitra, and possibly Pustulobolus; Figures 10-11).

This lower, diverse brachiopod fauna of the TST of the lower Forteau Formation contrasts significantly with a younger fauna (faunal assemblage 2) that coincides with rocks of the HST, particularly the Upper limestone that commenced with a seaward advancing complex of archeocyathid biostroms (southern Labrador; Figure 10) and bioherms (Route 463 to MSM) associated with high-energy interreef channel fills and shoals of oolitic and bioclastic grainstone (Figure 11). The barrier complex succeeded by carbonate-dominated heterolithic parasequences support a pro- 


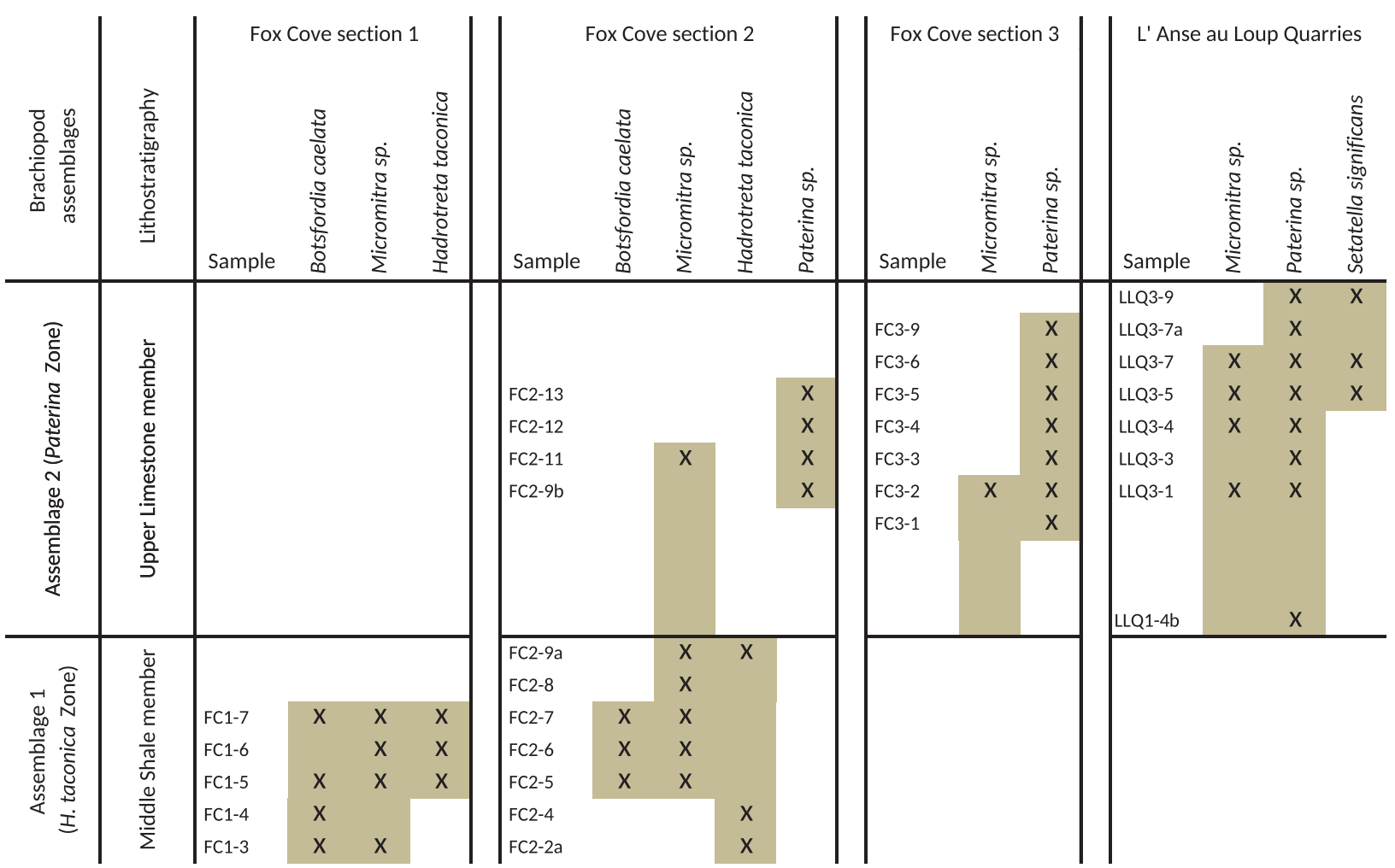

FIGURE 10. Distribution of brachiopod taxa recovered from sections measured in the Forteau Formation of the south Labrador coast. Shaded area indicates known stratigraphic range of individual taxa. Correlation of adjacent sections is approximate only. For more exact correlation of sections and samples see Figure 3.

grading high stand system tract (Knight et al., 2017). Eocrinoids and Salterella form important elements of the carbonate banks throughout the formation but the brachiopod fauna is replaced by an almost exclusively paterinid assemblage (Micromitra, Paterina with rare Setatella) in the upper reefal complexes of southern Labrador and northwest Newfoundland as well as the upper heterolithic succession in northwest Newfoundland.

The identical vertical distribution of brachiopods in both southern Labrador and the western side of the GNP, Newfoundland, makes it possible to recognize two distinct brachiopod biozones associated with the inner shelf facies of the Forteau Formation (Figures 10-11); a lower Hadrotreta taconica Zone (containing Hadrotreta taconica, Kyrshabaktella diabola, Botsfordia caelata, Pustulobulus triangulus, and Micromitra sp. in addition to the calcareous brachiopods Obollella sp. and Kutorgina sp.) and an upper Paterina Zone (containing Paterina sp., Micromitra sp. and Setatella significans). The decrease in brachiopod diversity from assemblage 1 of the TST to the stratigraphically overlying assemblage 2 of the HST is mirrored by a contemporaneous decrease in diversity of archaeocyathans (Debrenne and James, 1981) as well as other faunal elements (CBS personal observation). The reasons behind the decrease in diversity remain elusive, but the pattern indicates an increasingly stressed environment, perhaps related to increasing energy conditions and storms related to a shallowing, prograding shelf.

In the quarry at Mount St. Margaret in western Newfoundland brachiopods are found in calcareous nodules in mudrocks of the lower Middle shale (Figure 11). The fauna from these layers is reminiscent of assemblage 1, including Hadrotreta taconica and a single specimen of Kyrshabaktella diabola. Botsfordia, however, is replaced by the new genus Pustulobulus that is not known with certainty from either archaeocyathan rich layers in the inner shelf facies belt or from the deep-water facies of the Bonne Bay area. Consequently, it may be possible to suggest Pustulobolus as an indicator for soft bottom environments of intermediate water depth. However, the species may occur with archaeocyathans of the interreef facies of the lower patch reef complex in southern Labrador (Spencer, 


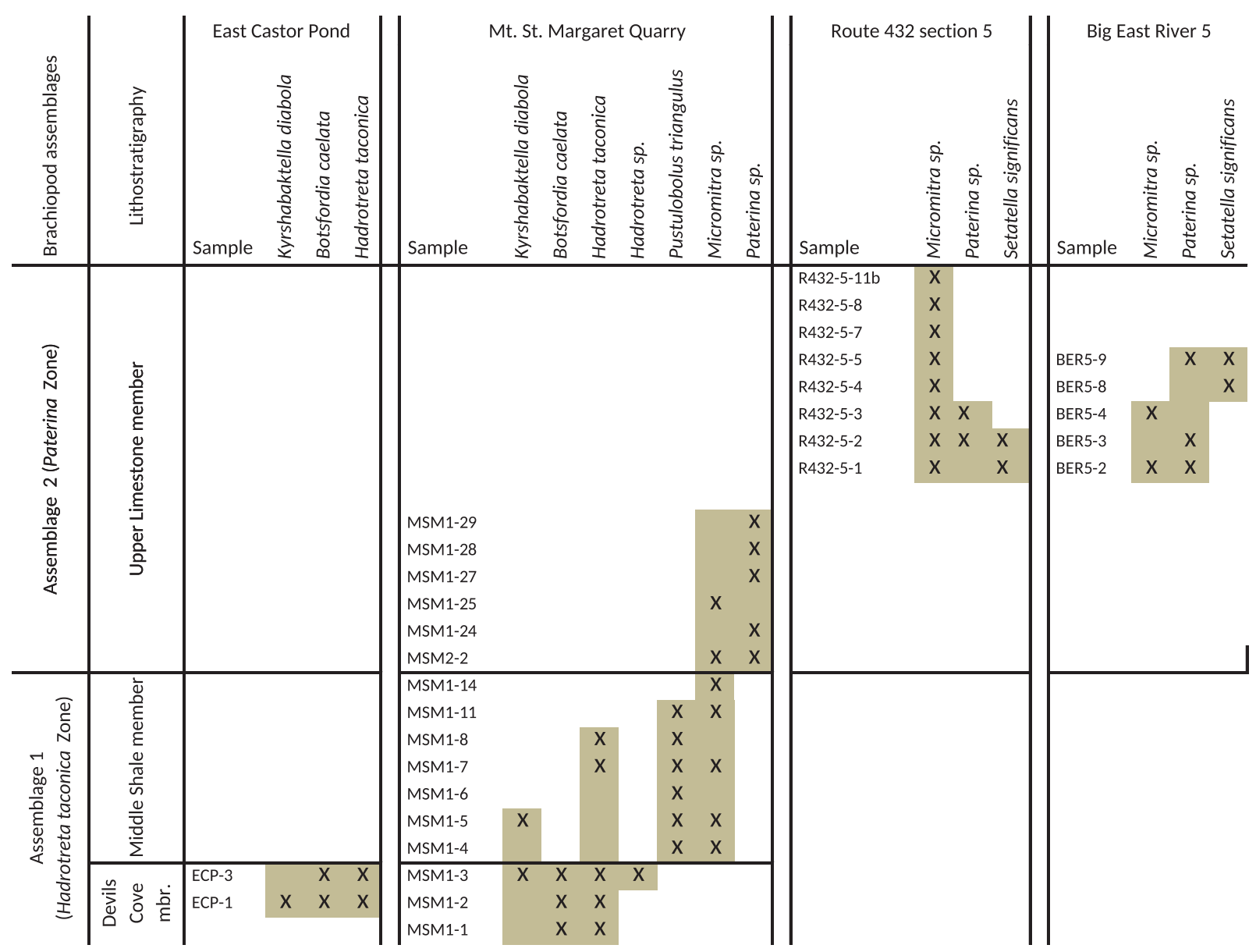

FIGURE 11. Distribution of brachiopod taxa recovered from sections measured in the Forteau Formation of the Great Northern Peninsula of western Newfoundland. Shaded area indicates known stratigraphic range of individual taxa. Correlation of adjacent sections is approximate only. For more exact correlation of sections and samples see Figures 6-7.

1980); further sampling will be required to resolve this matter.

\section{Outer Shelf Deep-water Fauna}

The argillaceous facies of the Forteau Formation in the Bonne Bay area of western Newfoundland is interpreted to represent deposition in relatively deep water of an outer shelf setting (Knight, 2013). The thin Devils Cove member in the area, which presumably was deposited in relatively shallow water, only yielded few brachiopod specimens. The deep-water brachiopod fauna and the associated fauna of Small Shelly Fossils described by Skovsted and Peel (2007) were recovered from dark limestone layers in the otherwise mudrock dominated sequence of the Mackenzie Mill member, particularly the Deer Arm limestone and the upper limestone interval. The brachiopod fauna (assemblage 3 ) is diverse but with highly variable proportions of individual species per sample. Numerically the assemblage is dominated by Hadrotreta taconica, Micromitra sp. and Eothele tubulus while Eoobolus priscus, Acrothyra bonnia $\mathrm{n}$. sp.and the calcareous Obolella sp. occur in small numbers.

The brachiopod fauna of the Devils Cove member in the Bonne Bay area is anomalous compared to the fauna of the same unit elsewhere. In the light coloured limestones making up the bulk of the unit only rare specimens of Setatella significans were recovered (Figure 12). In the Forteau Formation of the inner shelf, S. significans is otherwise only known from the rocks of the HST, particularly the Upper limestone of southern Labrador and the GNP (Figures 10-11). This disjunct distributional pattern is unique to $S$. significans among all brachiopod species in the Forteau Formation but since only very few specimens (often only shell 


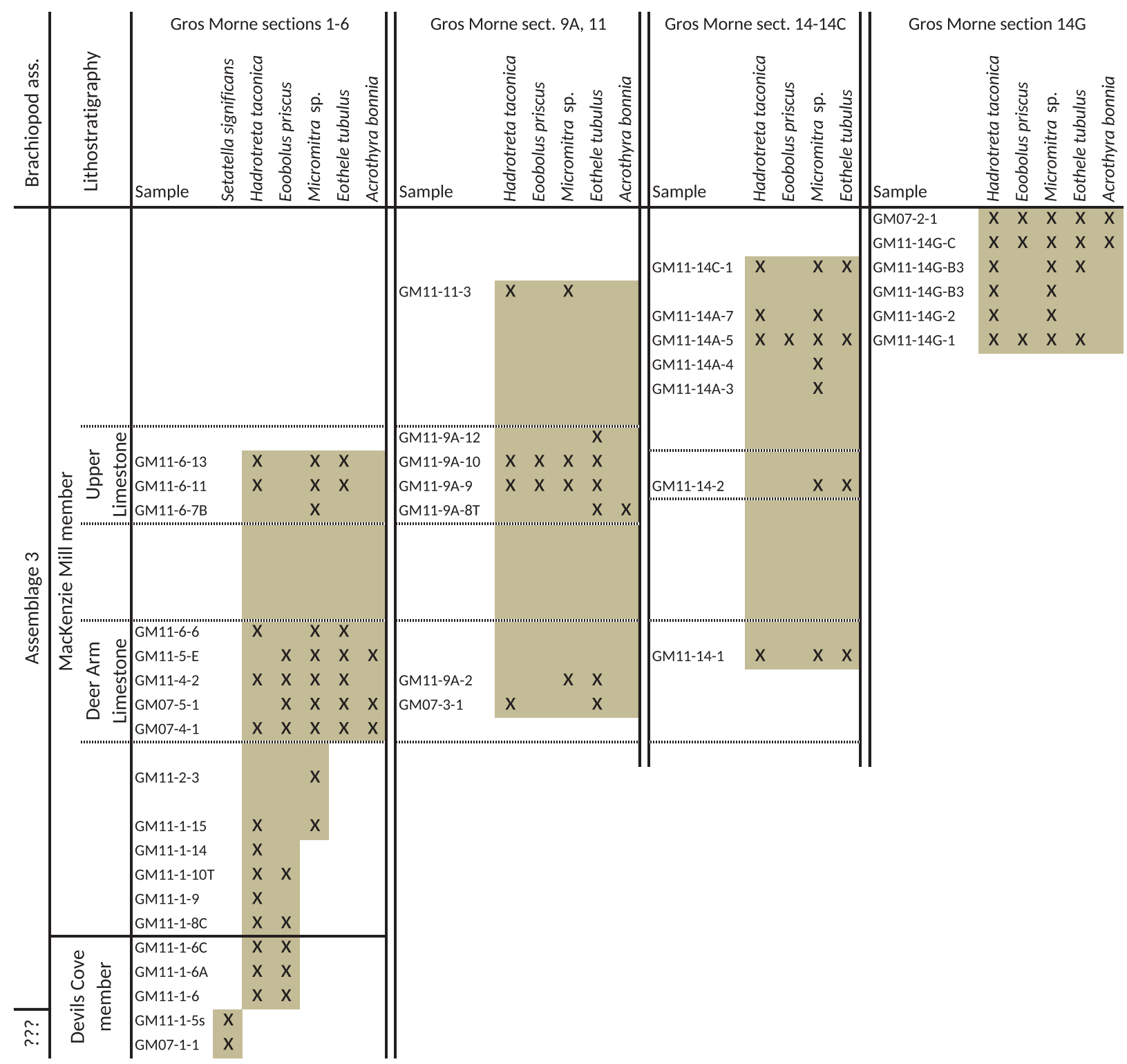

FIGURE 12. Distribution of brachiopod taxa recovered from sections measured in the Forteau Formation of the Gros Morne National Park of western Newfoundland. Shaded area indicates known stratigraphic range of individual taxa. Correlation of adjacent sections is approximate only. For more exact correlation of sections and samples see Figures 9-10.

fragments) were recovered, its importance is difficult to evaluate. Finer grained dark limestone interlayered with shale at the top of the Devils Cove member contains Hadrotreta taconica and Eoobolus priscus. This supports deepening seas during the early stages of transgression and a transition to the deep-water fauna of the Mackenzie Mill member.

In the lower part of the Mackenzie Mill member, Hadrotreta taconica, Eoobolus priscus, and rare Micromitra sp. are the only recovered brachiopods. Eothele tubulus and Actrothyra bonnia appear in the Deer Arm limestone, and this more diverse fauna persists throughout the remainder of the Mackenzie Mill member. No brachiopods were recovered from the overlying Big Hill member (Figure 12).

\section{Correlation of Deep and Shallow Water Fauna}

Based on the shared occurrence of Hadrotreta taconica, assemblage 3 of the deep-water facies from the Bonne Bay area south of the Long Range Mountains, at least below the DAL, is likely to represent the time equivalent of assemblage 1 in 


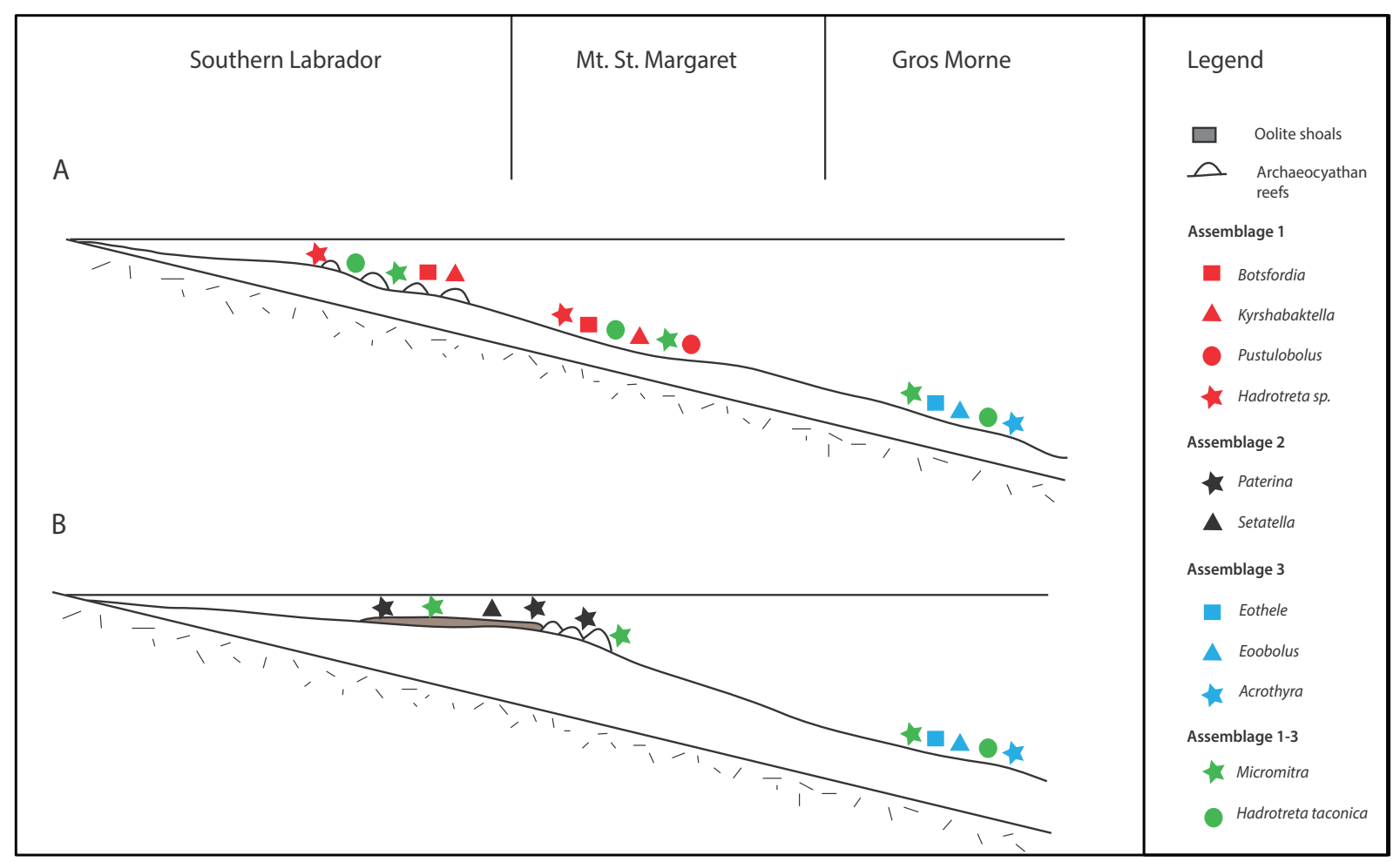

FIGURE 13. Environmental preferences of studied brachiopod taxa distributed along a simplified cross section of the eastern Laurentian shelf during the early Cambrian with the relative position of the three general study areas indicated. A. Representing the environment during the deepening phase of the transgressive systems tract (Middle shale of Labrador and the Great Northern Peninsula and Devils Cove member and lower part of the Mackenzie Mill member in Gros Morne area). B. Representing the environment during the regressive high stand system tract with the development of a prograding shelf (Upper limestone of Labrador and the Great Northern Peninsula and the upper part of the Mackenzie Mill member in Gros Morne area).

a deep water setting. This is plausible since both these faunas are associated with the TST of the Dyerian Labrador Group megasequence. This interpretation is corroborated by the presence of the trilobites Bonnia parvula and $B$. senecta as well as Calodiscus lobatus in both the shallow water facies of Labrador and in lower part of the Mackenzie Mill member (up to the DAL). Correlation of the upper part of the Mackenzie Mill member is less straightforward. However, the stratigraphical range of all brachiopod taxa of assemblage 3 extends into the shallowing interval of the upper Mackenzie Mill member (Figures 9, 12). This suggests that the upper range of assemblage 3 may correlate with assemblage 2 of the HST stage in the inboard section of the shelf, which is supported by the presence of the trilobites Olenellus thompsoni, $\mathrm{O}$. transitans, and Wanneria walcottana in the same intervals. This means that assemblage 3 may represent a widespread and long-ranging fauna that remained unchanged in relatively deep-water set- tings while brachiopod communities were replaced in more shallow water environments, presumably as a consequence of changing conditions on the sea floor (Figure 13).

\section{EARLY CAMBRIAN ORGANOPHOSPHATIC BRACHIOPOD FAUNAS FROM LAURENTIA}

The total brachiopod fauna of the Forteau Formation is very similar to the majority of described faunas of early Cambrian brachiopods occurring at several different localities along the Cambrian margins of eastern Laurentia, including Pennsylvania (Skovsted and Peel, 2010), New York (Landing and Bartowski, 1996), Vermont (Lochman, 1956), Quebec (Landing et al., 2002), and North-East Greenland (Skovsted and Holmer, 2005). This appears to also apply to the majority of other early Cambrian shelly taxa described from Pennsylvania to NorthEast Greenland (Skovsted, 2004, 2006; Skovsted and Peel, 2007, 2010), indicating that no substan- 
tial barriers to the dispersal of shelly faunas existed along the east Laurentian shelf at this time.

The majority of early Cambrian faunas from eastern Laurentia described to date are derived from either proximal turbidites in a continental slope setting in the Taconic allochthons of New York State and Quebec (Landing and Bartowski, 1996; Landing et al., 2002) or storm event beds in an outer shelf setting as in North-East Greenland and Pennsylvania (Skovsted, 2006; Skovsted and Peel, 2010). These faunas are often taxonomically rich, but are likely to incorporate fossils derived from vastly different sedimentological settings along the palaeoshelf. The Forteau Formation of southern Labrador and western Newfoundland is the only preserved lower Cambrian rock unit along the east Laurentian margin that includes sediments deposited more or less simultaneously in different environmental settings, from the very shallow archaeocyathid reef facies in southern Labrador to argillaceous distal outer shelf facies east and south of the Long Range Mountains in western Newfoundland.

\section{Comparison to North-East Greenland}

Brachiopod faunas from North-East Greenland (Skovsted and Holmer, 2005) are strikingly similar to those of the Forteau Formation and provide a possible test for the distributional patterns documented herein. However, in North-East Greenland rock units representing different facies belts are found in vertical and not lateral continuity. Nevertheless, Skovsted and Holmer (2005) noted distinctively different brachiopod faunas in the upper Bastion Formation (argillaceous distal shelf facies) and the overlying carbonate dominated Ella Island Formation with only a single species common to both faunas (Setatella significans sensu Skovsted et al., 2010). The majority of taxa present in the North-East Greenland faunas are also present in the Forteau Formation and the facies distributional pattern is also similar (Skovsted and Holmer, 2005). The most notable exception is the presence of Botsfordia caelata in the upper Bastion Formation, seemingly at odds with the exclusive occurrence of this species in shallow water facies, particularly the patch reef association, of the Forteau Formation.

The bulk of the material from the Bastion Formation available to Skovsted and Holmer (2005) was derived from two sections, at the Albert Heim Bjerge region and C.H. Ostenfeld Nunatak, respectively. These sections differ slightly in sedimentology, and Skovsted $(2004,2006)$ interpreted the
TABLE 2. Distribution of Botsfordia caelata (Hall, 1847) and Eoobolus priscus (Poulsen, 1932) in GGU (Grønlands Geologiske Undersøgelse - now part of the Geological Survey of Denmark and Greenland) samples collected from the upper Bastion Formation at Albert Heim Bjerge and C.H. Ostenfeld Nunatak of North-East Greenland. Absolute number of specimens for each investigated GGU sample with relative proportions of the two species for each area indicated. See Skovsted and Holmer (2005) and Skovsted $(2004,2006)$ for more details.

\begin{tabular}{|c|c|c|c|}
\hline Section + sample & Taxon & $\begin{array}{l}\text { Botsfordia } \\
\text { caelata }\end{array}$ & $\begin{array}{c}\text { Eoobolus } \\
\text { priscus }\end{array}$ \\
\hline \multicolumn{4}{|l|}{ Albert Heim Bjerge } \\
\hline GGU 314804 & & 10 & \\
\hline GGU 314806 & & 8 & \\
\hline GGU 314807 & & 61 & \\
\hline GGU 314808 & & 19 & \\
\hline GGU 314809 & & 23 & 97 \\
\hline GGU 314835 & & 246 & \\
\hline GGU 314836 & & & 5 \\
\hline \multirow[t]{3}{*}{ GGU 314837} & & 1 & 9 \\
\hline & $\Sigma$ & 368 & 111 \\
\hline & $\%$ & $77 \%$ & $23 \%$ \\
\hline \multicolumn{4}{|c|}{ CH Ostenfeld Nunatak } \\
\hline GGU 314901 & & 2 & 3 \\
\hline GGU 314903 & & 7 & 3 \\
\hline GGU 314904 & & 5 & 38 \\
\hline GGU 314906 & & & 75 \\
\hline GGU 314908 & & 4 & 61 \\
\hline GGU 314909 & & 1 & 9 \\
\hline GGU 314910 & & 22 & 5 \\
\hline GGU 314918 & & 61 & \\
\hline GGU 314919 & & 2 & \\
\hline GGU 314931 & & & 21 \\
\hline GGU 314933 & & 12 & 94 \\
\hline GGU 314934 & & & 3 \\
\hline GGU 314936 & & & 2 \\
\hline \multirow[t]{3}{*}{ GGU 314937} & & & 1 \\
\hline & $\Sigma$ & 116 & 315 \\
\hline & $\%$ & $27 \%$ & $73 \%$ \\
\hline
\end{tabular}


section at C.H. Ostenfeld Nunatak as more offshore. The documented faunas of molluscs and small shelly fossils at C.H. Ostenfeld Nunatak differ relatively little from that of Albert Heim Bjerge in taxonomic composition, but greatly in relative abundance of taxa (Skovsted, 2004, 2006), and the same applies to brachiopods. Of particular interest here is the relative abundance of Botsfordia caelata and Eoobolus priscus, both of which are found in both sections. In the slightly more shallow Albert Heim Bjerge section, E. priscus is rare compared to $B$. caelata in terms of both number of occurrences and absolute numbers of specimens while the situation is reversed in the deeper water section at C.H. Ostenfeld Nunatak. Skovsted and Holmer did not publish the exact number of specimens from each sampled Greenland horizon, but this data is summarized for $B$. caelata and $E$. priscus in Table 2 herein. Based on comparison with the results presented for the Forteau Formation herein, these differences could be interpreted to indicate that the environment at Albert Heim Bjerge was shallow enough to support a significant population of $B$. caelata, or alternatively a greater influx of shells derived from nearshore environments at this site.

\section{Pennsylvania and the Taconic Allochthons}

A brachiopod fauna from the basal Kinzers Formation in Pennsylvania was described by Skovsted and Peel (2010). The Kinzers Formation has been interpreted to represent a shallowing upward basin to shelf transition (Skinner, 2005) and the brachiopod fauna described by Skovsted and Peel (2010) was derived from the basal part of the lower Emigsville Member, which is mainly composed of dark shales (which have also yielded the exceptionally preserved Kinzers lagerstätte; Skinner, 2005). The brachiopod fauna of the basal Kinzers Formation is similar to assemblage 3 of the Forteau Formation in the presence of Eothele tubulus, Eoobolus priscus, Micromitra sp. and Hadrotreta taconica (the latter reported as Hadrotreta sp. by Skovsted and Peel, 2010). The near identical faunas from two units separated by a substantial geographic distance but deposited in similar sedimentological settings seem to confirm a strong environmental control of early Cambrian brachiopod faunas in eastern Laurentia. Above the Emigsville Member the Kinzers Formation contains sediments deposited in more shallow environments (York, Longs Park, and Greenmount members; Skinner, 2005), but little is known about their brachiopod faunas and no comparison to the shallow water faunas of the Forteau Formation can be made at present.

Botsfordia caelata is relatively common in the Taconic allochthons of New York State and Vermont (Walcott, 1912; Lochman, 1956), and Eoobolus priscus is also known to occur in the region (Landing and Bartowski, 1996; see discussion in Skovsted and Holmer, 2005) but a detailed assessment of their relative distribution in this area is beyond the scope of the present contribution. However, Lochman (1956, p. 1371) notes that $B$. caelata in her material from Vermont is most common in limestones deposited in "a somewhat clearer water habitat," which may potentially indicate relatively shallow environments. Hadrotreta taconica is also known from the area (Walcott, 1912; Lochman, 1956; Landing et al., 2002) as well as several species of Micromitra and Paterina (Walcott, 1912) suggesting that the brachiopod fauna of this region is closely comparable to that of the Forteau Formation.

\section{Western Laurentia}

In western Laurentia, roughly coeval brachiopod assemblages are known from the Great Basin (Rowell, 1966, 1977, 1980) and the Canadian Rocky Mountains (Voronova et al., 1987; Balthasar, 2004, 2007, 2008, 2009). The Mural Formation of the Canadian Rocky Mountains is older than the Forteau Formation (Nevadella to basal Olenellus zone; Balthasar, 2004), and brachiopods have been reported from the upper, argillaceous part of the formation representing deepwater facies. The Mural Formation from sections in Jasper National Park (eastern British Columbia and western Alberta) has yielded a brachiopod fauna containing the stem group brachiopod Mickwitzia muralensis, and unidentified species of Eoobolus and Kyrshabaktella as well as three different obolellids (Balthasar, 2004, 2007, 2008, 2009). The co-occurrence of Eoobolus and Kyrshabaktella in the Mural Formation appear to be at odds with the distributional pattern from the Forteau Formation. However, unlike the associated Mickwitzia and obolellid taxa that occur in both shale and limestone, Eoobolus and Kyrshabaktella were only found in cross-bedded limestone lenses that Balthasar (2004) interpreted as eventbeds containing transported material. Further, Eoobolus vastly outnumbers Kyrshabaktella in the Mural Formation (Balthasar, 2007 reported 232 specimens of Eoobolus and 1 specimen of Kyrshabaktella). It is thus possible that the rare Kyrshabaktella in the Mural Formation could be derived from more shal- 
low environments than co-occurring Eoobolus, mirroring the distribution of Botsfordia in the Bastion Formation of North-East Greenland discussed above.

A diverse brachiopod fauna was also reported from the Sekwi Formation in the Mackenzie Mountains of the Northwest Territories, Canada (Voronova et al., 1987). The fauna includes Micromitra (described under both Paterina and Micromitra; Voronova et al., 1987, p. 51), Eothele tubulus, an acrotretid (Linnarssonia) and two poorly known lingulids (described as Palaeoschmidtites and Lingulella?). However, as the fauna (with the exception of Palaeoschmidtites and Lingulella?) is confined to a single horizon, it is not possible to compare the distribution of the brachiopods from the Mackenzie Mountains with the fauna from the Forteau Formation, although the presence of Eothele tubulus conforms to the deep-water origin of the assemblage.

In the Great Basin of the western United States, lower Cambrian brachiopods are known from a number of localities and rock units (Rowell, 1966, 1977, 1980; Skovsted and Holmer, 2006). The depositional environment of the Great Basin is relatively well known and three major environments are recognized; inner, middle and outer shelf facies (Stewart, 1970; Webster, 2011). Although brachiopods are known from all three facies belts, the distributions of individual taxa remain poorly understood, and a detailed discussion of this topic is presently impossible. Rowell $(1977,1980)$ for example described brachiopod faunas from southwestern Great Basin (outer shelf region; Rowell, 1977 ) and the Pioche region of eastern Great Basin (middle to inner shelf region; Rowell, 1980). No brachiopod taxa are identical in the two faunas, and the environmental importance of the faunal differences is impossible to evaluate because there is also a substantial difference in age between the assemblages (basal Dyeran in southwest and uppermost Dyeran to Delamaran in the east).

From North Greenland, Peel et al. (2016) recently described a diverse fauna of the Paralledal Formation at Löndal containing a number of brachiopod taxa, including Eoobolus priscus as well as acrothelid, acrothretid, and zhantanellid taxa. This fauna is somewhat similar to the fauna of the Forteau Formation, although the associated trilobites indicate a younger age (Peel et al., 2016). Differences in faunal composition at different stratigraphical levels at Löndal (lingulids below and acrotretids above a prominent sandstone unit) are difficult to compare to the distributional patterns documented for the Forteau Formation here as the rocks are thought to represent deposition from turbidites.

\section{ENVIRONMENTAL CONTROL OF BRACHIOPOD DISTRIBUTION IN THE CAMBRIAN}

Following pioneering work on brachiopod faunas from the Silurian of Wales (Ziegler, 1965; Ziegler et al., 1968), brachiopods have been used as major tools for defining distinct benthic assemblage zones characteristic of increasing water depth (assemblages BA1-BA7) in Palaeozoic rocks (Boucot, 1975; Cocks, 1996; Azmy et al., 2006 and references therein). However, little is known about the connection between brachiopod assemblages and water depth in the Cambrian period. Brachiopods have long been known to occupy a wide range of environments in the Cambrian (see reviews in Bassett et al., 1999 and Ushatinskaya, 2001) but the relationship between genus or species level distribution and environment have rarely been analyzed. Some authors have reported extremely wide environmental distribution of Cambrian brachiopod taxa (McBride, 1976) while others have suggested that early Cambrian brachiopods were essentially restricted to shallow water environments (Cocks, 1996), although some genera have been reported from Carbonate platforms (Bassett et al., 1999).

Brachiopod faunas from the lower Cambrian have been described from all palaeocontinents (Holmer et al., 1996; Gravestock et al., 2001; Zhang et al., 2008; Rozanov et a., 2010; Kouchinsky et al., 2012; Popov et al., 2015 and references therein). However, no detailed analysis of the connections between species distribution and depositional environment has been published beyond the general accounts presented by Bassett et al. (1999) and Ushatinskaya (2001).

On a general level, larger taxonomic groups among the Cambrian Brachiopoda have been associated with specific environments but the pattern is usually complex. One example is the obolellids that have been associated with reefal environments (Ushatinskaya, 2001) but which have also been demonstrated to occur in finegrained siliciclastic sediments (Balthasar, 2008; Zhang et al., 2011). In a similar way Cambrian lingulids have been associated mainly with siliciclastic facies (Ushatinskaya, 2001) but the fauna of the Forteau Formation appears to show that some species at least preferred shallow water carbonate environments. 
New information on the autecology of Cambrian brachiopods has recently come from studies on brachiopods with preserved soft parts (Zhang et al., 2004; 2009, 2011; Petterson Stolk et al., 2009) and the physical association of brachiopods with other organisms (Holmer and Caron, 2006; Zhang et al., 2007, 2010; Topper et al., 2014, 2015) in the Chengjiang and Burgess Shale lagerstätten. Although many taxa have long pedicles, present evidence suggests that few Cambrian brachiopods were infaunal like the Recent Lingula Bruguière, 1791 (see discussion in Bassett et al., 1999, Zhang et al., 2008 and Topper et al., 2015), although rare burrowing traces of probable linguliform brachiopods have been described from sandstones with abundant Skolithos burrows of the Bradore Formation of southern Labrador (Pemberton and Kobluk, 1978). The general pattern from studies of brachiopods from Cambrian lagerstätten is that most taxa appear to be epifaunal suspension feeders (Bassett et al., 1999) that attached directly to the seafloor, to dead shells or living members of the benthos such as algae, sponges, chancelloriids, or even other brachiopods (Mergl, 2002; Holmer et al., 2005, Holmer and Caron, 2006; Zhang et al., 2004, 2007, 2008, 2010, 2011; Topper et al., 2015). Burrowing lifestyles among brachiopods in the Cambrian were likely restricted to nearshore arkosic environments. Consequently, all brachiopod taxa from the Forteau Formation were likely epifaunal suspension feeders, and differences in their distribution likely reflect differences in substrate choice. Although the present study does not yield any specific evidence as to the preferred substrate of any of the recovered brachiopod species, comparison to presumably closely related species from lagerstätten suggest that the paterinids Paterina and Micromitra attached directly to other organisms such as sponges or other types of hard substrates such as brachiopod shells or trilobite sclerites (Topper et al., 2015). The acrotretids Hadrotreta and Acrothyra may have been associated with algal fronds, like Kuangshanotreta from the Chenjiang lagerstätte (Wang et al., 2012) or hexactinellid sponges like some Ordovician taxa (Mergl, 2002; Holmer et al., 2005). Lingulids similar to Eoobolus, Kyrshabaktella and Pustulobolus from Cambrian lagerstätten typically have long, flexible pedicles which have been interpreted to have held the shells 'kite-like' above the sediment surface with only the distal part of the pedicle embedded in the sediment (Zhang et al., 2008). Finally, by comparison to the related species Diandongia pista Rong, 1974, from Chengjiang, the shell of Botsfor- dia probably rested directly on the sea floor although it was attached to hard substrates by a narrow pedicle (Zhang et al., 2003), while early rhynchonelliform brachiopods such as Obolella and Kutorgina may have been attached to hard substrates via short, stout pedicles (Zhang et al., 2008).

The observed distributional differences between the phosphatic brachiopod taxa in the Forteau Formation documented here indicate that regardless of general life mode, many Cambrian brachiopods may have been quite specific in their choice of environment. Closely related species, such as the two acrothelids Botsfordia caelata and Eothele tubulus and the two eooboloids Pustulobolus triangulus and Eoobolus priscus exhibit completely opposite distributional trends and are characteristic of different facies assemblages. This would suggest that the distributional patterns are influenced by differences in depth-related ecological requirements on the generic or specific level, which in turn may translate to differences in choice of substrate. As discussed above, available evidence, although patchy at the present time, shows that similar environmental constraints determine the distribution of brachiopods elsewhere along the eastern palaeocoast of Laurentia and perhaps also in western Laurentia.

These results suggest that if similar distribution patterns can be observed for brachiopods from other Cambrian outcrop areas, individual genera or species of organophosphatic brachiopods could potentially be used as indicators of palaeodepth for the Cambrian. The evidence from brachiopod distribution in the Forteau Formation suggest that at least Botsfordia caelata, Pustulobolus triangulus, and Paterina sp. can be interpreted as tied to shallow water environments while Eoobolus priscus, Eothele tubulus, and Acrothyra bonnia are characteristic of deeper water.

Faunas, potentially comparable to the fauna of the Forteau Formation, both in terms of taxonomic composition and diversity are found in many parts of the world. One example is from Shaanxi Province of South China where $\mathrm{Li}$ and Holmer (2004) described diverse brachiopods from the Xihaoping and Shuijingtuo formations including species of Eoobolus, Kyrshabaktella, and Botsfordia as well as Palaeobolus, Lingulellotreta, and Eohadrotreta. Although the Shaanxi brachiopod fauna appear to change with lithostratigraphy, the exact relationship of individual taxa to water depth is uncertain. Similar faunas containing species of Botsfordia, Eoobolus, and Kyrshabaktella occur in 


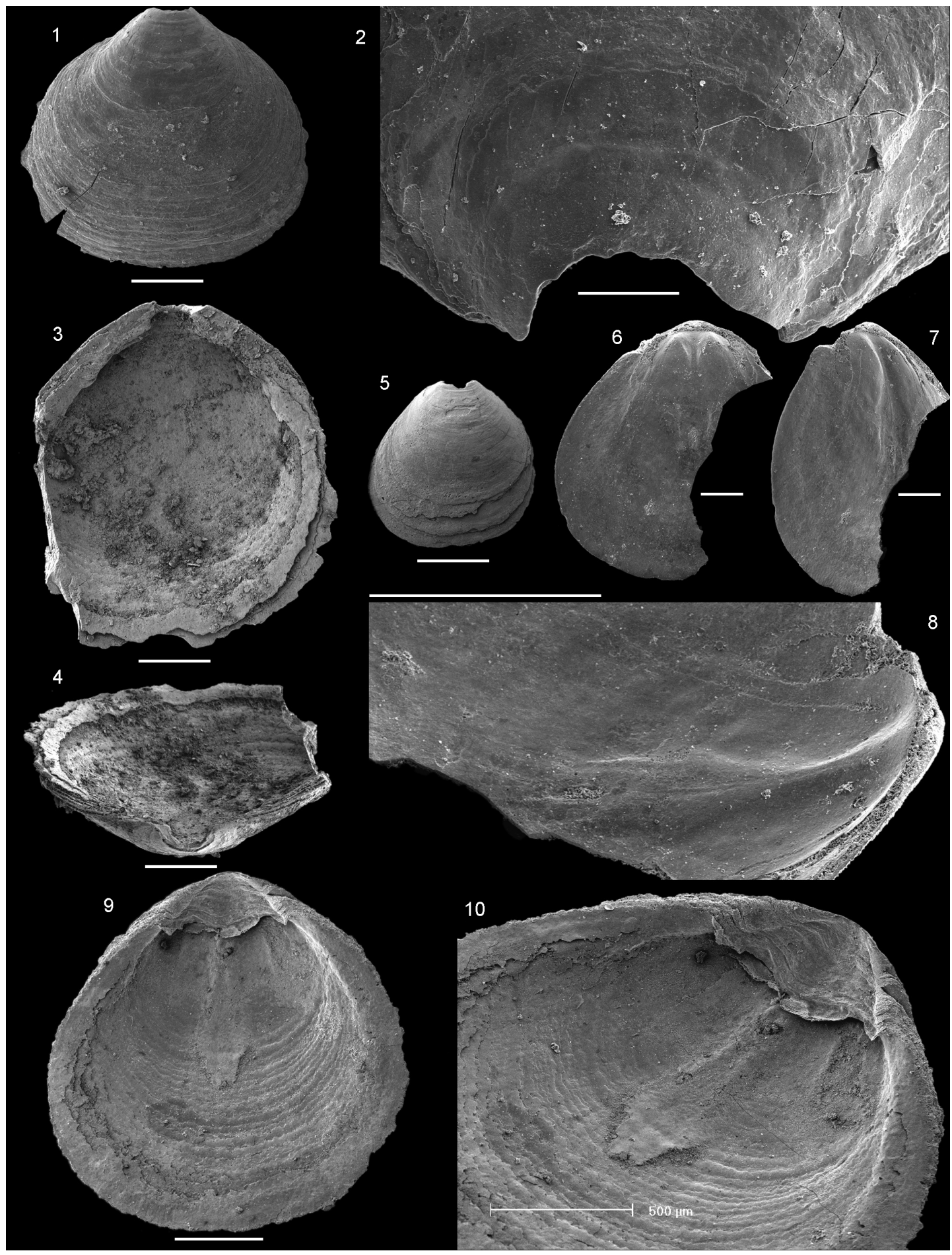

FIGURE 14. Kyrshabaktella diabola n. sp. from the Forteau Formation of southern Labrador and western Newfoundland. 1-2, Ventral valve NFM F-2516 from Devils Cove member, East Castor Pond, sample ECP-01; 1, external view; 2, detail of larval shell and resorbed pedicle groove. 3-4, Ventral valve NFM F-2517 (Holotype) from Devils Cove member, Mount St. Margaret, sample MSM-03; 3, internal view; 4, oblique posterior view showing pedicle groove. 5, Ventral valve exterior NFM F-2518 from Devils Cove member, Mount St. Margaret, sample ICS1520. 6-8, Dorsal valve NFM F-2519 from Lower Shale member, Mount St. Margaret, sample MSM-5; 6, internal view; 7, oblique internal view; 8, detail of internal surface showing vascula lateralia and median tongue with muscle scars. 9-10, Dorsal valve NFM F-2520 from the Lower shale, Fox Cove, sample ICS1575; 9, internal view; 10, detail of dorsal interior showing dorsal pseudointerarea and median tongue. All scalebars equal $500 \mu \mathrm{m}$ except in figure 2 where the bar equals $125 \mu \mathrm{m}$ 
other parts of the world as well. However, a thorough comparison to the environmental distribution patterns on a global scale of these particular taxa is beyond the scope of the present publication.

\section{SYSTEMATIC PALAEONTOLOGY}

Repository. Unless otherwise indicated, all types and figured specimens are housed in the Provincial Museum of Newfoundland and Labrador (NFM), St. John's, Newfoundland, Canada.

Phylum BRACHIOPODA Duméril, 1806 Subphylum LINGULIFORMEA Williams, Carlson, Brunton, Holmer, and Popov, 1996

Class LINGULATA Gorjansky and Popov, 1985

Order LINGULIDA Waagen, 1885

Superfamily LINGULOIDEA Menke, 1828

Family KYRSHABAKTELLIDAE Ushatinskaya in Pelman et al., 1992

Genus KYRSHABAKTELLA Koneva, 1986

Type Species. Kyrshabaktella certa Ushatinskaya in Pelman et al., 1992.

\section{Kyrshabaktella diabola n. sp.}

Figure 14

zoobank.org/BB40AC4D-B815-4FA6-8573-5028CA144F8F

Holotype. Ventral valve NFM F-2517 from Devils Cove member, Mount St. Margaret, sample MSM3.

Etymology. After Latin Diabolus in reference to the derivation of the majority of specimens from the Devils Cove member in western Newfoundland.

Diagnosis. Species of Kyrshabaktella with biconvex, sub-triangular to oval shell. Ventral valve with narrow pseudointerarea with parallel-sided pedicle groove and high, raised propareas without flexurelines. Dorsal valve with wide, triangular pseudointerarea dominated by slightly raised diamondshaped median groove separated from raised propareas by sharp folds. Dorsal valve interior with low, tongue-like median ridge expanding into a low platform anterior of mid-valve.

Differ from all other species of Kyrshabaktella by the narrow ventral pseudointerarea with paralellsided pedicle groove and elongated, curved propareas, and by the wide dorsal pseudointerarea with raised, diamond-shaped median groove.

Material. Three ventral and one dorsal valve from the Devils Cove member of the Forteau Formation of western Newfoundland (MSM-3, MSM-5, ECP3 , ICS1520) and a single dorsal valve from the lower Forteau Formation of southern Labrador (ICS1575).
Description. Slightly biconvex brachiopod shell with sub-circular to oval outline (Figure 14.1-9); shell length and width about 2-3 mm. Apex of both valves marginal, ventral valve with hemicircular, posteriorly open emarginature, about $0.2-0.3 \mathrm{~mm}$ wide (Figure 14.2-4). Larval shells poorly differentiated but appear to be sub-circular. Valve exterior otherwise ornamented with fine concentric ridges (Figure 14.1-2). Orthocline ventral pseudointerarea narrow and elongated along a substantial portion of the posterolateral shell margins, up to about a third of valve length (Figure 14.3). Pedicle groove narrow, almost parallel-sided, and continuous with valve floor. Propareas raised strongly above valve floor but without flexure lines. Dorsal pseudointerarea orthocline and sub-triangular, representing about $50 \%$ of valve width and $20 \%$ of valve length (Figure 14.9-10). Median groove wide, concave, and slightly raised above valve floor. The median groove is extended slightly anteriorly over the median ridge, resulting in a diamond-shape (Figure 14.9). The dorsal propareas are narrow but strongly raised above valve floor and differentiated from the median groove by sharp folds.

Ventral valve interior poorly preserved in available specimens. Dorsal valve interior with slightly raised median ridge which expands anteriorly to slightly anterior of mid-valve, into a tongue-like platform (Figure 14.6-10). The anterior termination of the median tongue is cleft by a small indentation and laterally bounded by elongated anterior-lateral musclescars (Figures 14.8, 14.10). Paired, triangular umbonal musclescars are inserted just below the pseudointerarea close to the junction of propareas and median groove (Figure 14.10). Short dorsal vascula lateralia are present between the umbonal musclescars and median tongue (Figure 14.8).

Remarks. Kyrshabaktella diabola is currently only known from a small number of specimens, but is quite distinct from all other species of Kyrshabaktella by the narrow ventral pseudointerarea with elongated, curved propareas, and the dorsal pseudointerarea with wide, slightly raised, and diamond-shaped median groove. The species is probably closely related to $K$. davidii Holmer and Ushatinskaya in Gravestock et al., 2001 from similarly aged rocks in South Australia (Betts et al., 2016, 2017) and K. tatjanae Ushatinskaya in Pelman et al., 1992 from the slightly younger Amgan Stage of the Altai-Sayan Foldbelt. Poorly preserved specimens referred to Kyrshabaktella sp. from the lower-mid Dyeran Stage of southern Nevada (Skovsted and Holmer, 2006) show a similar, dia- 


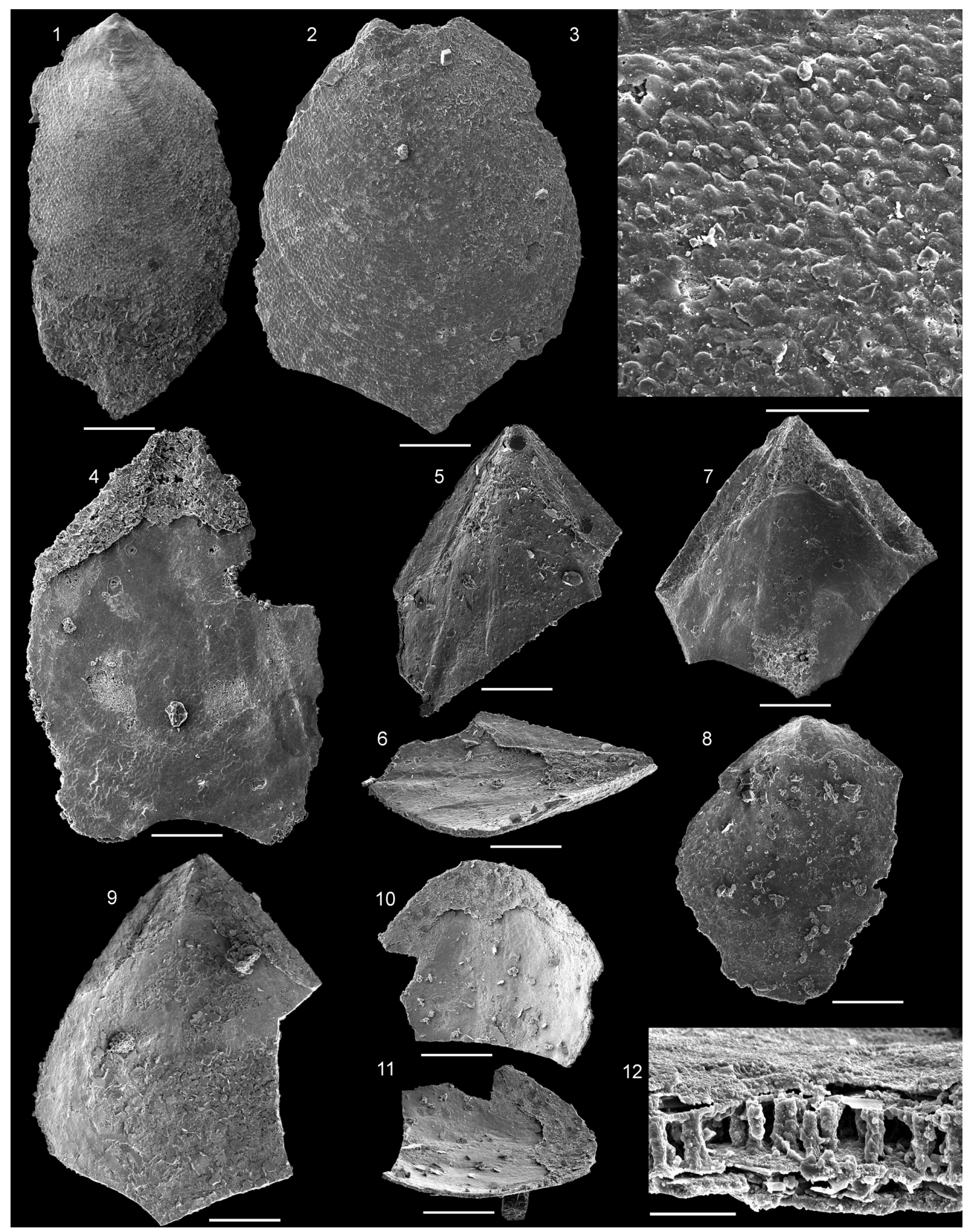

FIGURE 15. Eoobolus priscus (Poulsen, 1932) from the Forteau Formation of western Newfoundland. 1, Ventral valve exterior NFM 662 from Deer Arm Limestone, sample JSP 1982-01. 2-3, Ventral valve NFM F-2570 from Deer Arm Limestone, sample GM07-4-1; 2, external view; 3, detail of pustulose adult surface ornament. 4, Ventral valve interior NFM F-2571 from Deer Arm Limestone, sample GM07-4-1 showing arrangement of muscle scars. 5-6, Ventral valve NFM F-2574 from Deer Arm Limestone, sample GM07-5-1; 5, internal view; 6 , oblique interal view showing imprints of pedicle nerves. 7, Ventral valve interior NFM F-2572 from Deer Arm Limestone, sample GM07-4-1. 8, Dorsal valve NFM F-2522 from Deer Arm Limestone, sample ICS 1421. 9, Ventral valve interior NFM F-2566 from Mackenzie Mills member, sample GM11-9A-10. 10-12, Dorsal valve NFM F-2567 from Mackenzie Mills member, sample GM11-9A-10; 10 , internal view; 11 , oblique internal view; 12 , detail of columnar shell structure from naturally broken edge. Scalebars equal $250 \mu \mathrm{m}$ in figures 1-2 and 4-11, $50 \mu \mathrm{m}$ in figure 3 and $10 \mu \mathrm{m}$ in figure 12. 
mond-shaped dorsal median groove, but the propareas of both ventral and dorsal valves appear to be shorter than in $K$. diabola, and the Nevada specimens probably represent a distinct species. Skovsted and Holmer (2006) demonstrated a columnar shell structure in Kyrshabaktella sp. from Nevada, but no details of shell structure could be observed in $K$. diabola. A single specimen described as Fossuliella? sp. from the Löndal Formation of North Greenland is similar to K. diabola in shape of the ventral valve and the presence of a ventral emarginature (Peel et al., 2016). However, nothing is known about the dorsal valve morphology or ventral valve interior of Fossuliella? sp. and the Greenland specimen also differ from K. diabola in the fine pitting of both larval and adult shell.

Kyrshabaktella diabola appears to be restricted to relatively shallow water facies of the Devils Cove member and Middle shale in western Newfoundland and in the lower Forteau Formation at Fox Cove in southern Labrador; the small number of specimens precludes far reaching statements about its distribution. However, it appears to be present in strata that records the early momentum of shelf deepening and transgression (TST).

Distribution. Assemblage 1. Dyeran Stage (unnamed Cambrian Series 2, stage 4), Devils Cove member and Middle shale, Forteau Formation of southern Labrador and western Newfoundland, Canada.

Family EOOBOLIDAE Holmer, Popov, and Wrona, 1996

Genus EOOBOLUS Matthew, 1902

Type Species. Obolus triparilis Matthew, 1902.

Eoobolus priscus (Poulsen, 1932) Figure 15

v*1932 Lingulella (Lingulepis) prisca Poulsen, p. 13, plate 1, figures 1-5.

2005 Eoobolus priscus (Poulsen); Skovsted and Holmer, p. 330, plate 2, figures 1-13, plate 3, figures 1-11. (includes synonymy).

2006 Eoobolus priscus (Poulsen); Jago, Zhang, Sun, Paterson, and Skovsted, p. 413, figure $4 \mathrm{~m}, \mathrm{n}$.

2007 Eoobolus priscus (Poulsen); Skovsted and Peel, figure $2 \mathrm{a}, \mathrm{b}$.

2007 Eoobolus priscus (Poulsen); Paterson, Skovsted, Brock, and Jago, p. 138, figure 3a-e.

2010 Eoobolus priscus (Poulsen); Rozanov et al., p. 81, plate 49, figures 8-12.

2010 Eoobolus priscus (Poulsen); Skovsted and Peel, figure 2.22.
2014

2014

2016 Eoobolus priscus (Poulsen); Peel, Streng,

Eoobolus priscus (Poulsen); Ushatinskaya and Korovnikov, plate 5, figures 8-11.

Eoobolus priscus (Poulsen); Devaere, Clausen, Monceret, Vizcaïno, Vachard, and Genge, figure 12a-l. Geyer, Kouchinsky, and Skovsted, figure 8a$\mathrm{c}, \mathrm{e}, \mathrm{k}, \mathrm{m}$.

Holotype. Ventral valve MGUH 3503 from the upper Bastion Formation at Hyolithus Creek, North-East Greenland (Poulsen, 1932, plate 1, figure 3; Skovsted and Holmer, 2005, plate 2, figure 1).

Material. 42 ventral and 20 dorsal valves from the Forteau Formation of the Bonne Bay area, western Newfoundland (GM07-2.1, GM07-4.1, GM07-5.1, GM11-1-6, GM11-1-6A, GM11-1-6C, GM11-1-10T, GM11-4-2, GM11-5-E, GM11-9A-9, GM11-9A-10, GM11-14A-5, GM11-14G-1, GM11-14G-C, JSP1982-01, ICS1421; see appendices 1 and 2).

Diagnosis. See Skovsted and Holmer (2005), p. 332.

Description. This species is invariably represented in the Forteau Formation by fragmentary specimens, usually of the posterior part of the shell. Shell gently biconvex with sub-triangular outline. The ventral valve is elongated and posteriorly triangular with an apical angle of 75-90 degrees (Figure 15.1, 15.4, 15.5, 15.7, 15.9); the dorsal valve has a more rounded posterior margin (Figure $15.8,15.10)$. Juvenile shell poorly preserved in available specimens and no juvenile ornament could be identified. Adult valve ornamented by closely set sub-circular pustules with a diameter of 5-8 $\mu \mathrm{m}$ (Figure 15.3). Ventral pseudointerarea with narrow pedicle groove, somewhat expanding anteriorly, and raised propareas with well-defined flexure-lines (Figure 15.5, 15.7, 15.9). Dorsal pseudointerarea slightly raised above valve floor with wide, triangular but poorly defined median groove; slightly flexed anteriorly in central part (Figure 15.8, 15.10). Ventral valve interior with triangular impression of pedicle nerves (Figure 15.5-7) bisecting small, circular umbonal muscle scars (Figure 15.4) and larger scars in the posterior part of the anterior muscle field. Elongate posterolateral muscle scars inserted below propareas (Figure $15.4,15.6)$. Dorsal valve interior with elongate median tongue but otherwise poorly preserved (Figure 15.10). Internally the shell is composed of thin laminae bisected by multiple acrotretid-like columnar structures (Figure 15.12).

Remarks. Lingulella (Lingulepis) prisca was originally described from the Bastion Formation of North-East Greenland by Poulsen (1932). 
Skovsted and Holmer (2005) redescribed Poulsen's type material together with large collections from new sections in North-East Greenland and referred the species to Eoobolus based on the combination of a finely pitted larval shell and a pustulose adult shell. Eoobolus priscus has also been reported from the Löndal Formation of North Greenland (Peel et al., 2016). A columnar shell structure is described in Eoobolus for the first time by Peel et al. (2016), and this observation is corroborated by the find of a columnar shell structure in specimens from the Forteau Formation described here. Two specimens from the Forteau Formation identified as E. priscus were illustrated by Skovsted and Peel (2007), but new collections allow a more detailed comparison of the Newfoundland shells with the type material (in particular of the internal morphology) and confirms the identification.

Brachiopod shells from the lower Cambrian of Antarctica (Holmer et al., 1996) and South Australia (Ushatinskaya and Holmer in Gravestock et al., 2001) described as Eoobolus aff. elatus were placed in synonymy of E. priscus by Skovsted and Holmer (2005). Later investigations of new collections from the Stansbury Basin of South Australia has confirmed that E. priscus is present in this region (Jago et al., 2006; Paterson et al., 2007; Betts et al., 2017). Skovsted and Holmer (2005) also suggested that the poorly known Siberian species Eoobolus elatus Pelman in Pelman and Pereladov, 1986 is a junior synonym of $E$. priscus, an interpretation that was subsequently supported by Rozanov et al. (2010) and Ushatinskaya and Korovnikov (2014). Eoobolus priscus has also been described from the Pardailhan Formation, of the early Cambrian of Montagne Noire, France (Devaere et al., 2014). However, as discussed by Streng et al. (2008), specimens referred to Eoobolus? sp. aff. E. priscus (Poulsen, 1932) from the Cambrian Series 3 Forsemölla Limestone of southern Sweden differ from E. priscus by the lack of a pitted larval shell and in minor details of internal morphology and is not included in the species by us.

Specimens described as Lingulella cf. prisca were reported from the Forteau Formation of Labrador by Spencer (1980) but the illustrated shells were excluded from E. priscus by Skovsted and Holmer (2005); here we assign these specimens to the new genus Pustulobolus (see below). In our collections E. priscus appears to be restricted to the Gros Morne district where the species occurs from the top of the Devils Cove member throughout the Mackenzie Mills members (sections GM1 to $14 \mathrm{G})$. Throughout its range in the Forteau Formation, E. priscus is fairly common, although always in low numbers.

Distribution. Assemblage 3, upper part of Devils Cove member and Mackenzie Mill member, Forteau Formation of Gros Morne area, western Newfoundland. Dyeran Stage (Cambrian Series 2, Stage 3-4; approximately equivalent to the Adtabanian to Botoman stages of Siberia) of eastern Laurentia (North-East Greenland, Newfoundland, New York State, Pennsylvania), Botoman-Amgan Stages of Siberia (Rozanov et al., 2010); Stage 3-4 of Antarctica (glacial erratics on King George Island; Holmer et al., 1996), and South Australia (Arrowie and Stansbury basins; Gravestock et al., 2001; Betts et al., 2017).

\section{Genus PUSTULOBOLUS n. gen.}

\section{zoobank.org/0FC76582-4109-4D2E-B1F9-8EAF8C34011C}

Type species. Pustulobolus triangulus n. gen et. sp.

Diagnosis. Shell dorsibiconvex, strongly inequivalved linguliform brachiopod; larval shells small, subcircular with pitted microornament; adult valve exterior with anteriorly extended, spine like pustules increasing in size anteriorly; ventral valve with sharply pointed triangular posterior and rounded anterior margins with large orthocline pseudointerarea with narrow pedicle furrow and well developed flexurelines; adult external ornament covering ventral pseudointerareas lateral to flexurelines; dorsal valve subcircular with narrow, linear pseudointerarea, and low median ridge. Differ from Eoobolus by the larger pustules of the adult ornament, the larger size of the ventral pseudointerarea and the smaller pseudointerarea of the dorsal valve. Differ from Spinobolus by the denser distribution of spine like pustules and the larger ventral pseudointerarea. Differ from Botsfordia and other acrotheloids by the large, orthocline ventral pseudointerarea. Differ from Lingulellotreta by the pustulose adult ornament and the ventral pseudointerarea lacking a pedicle tube throughout ontogeny.

Etymology. The name is derived from the characteristic pustulose ornament of the adult shell and ventral pseudointerarea.

Remarks. Pustulobolus exhibits a peculiar combination of characters otherwise associated with different Cambrian linguliforms. The external ornament and the morphology of the dorsal valve interior is extremely similar to that of the acrotheloid genus Botsfordia, while the larval shell, 


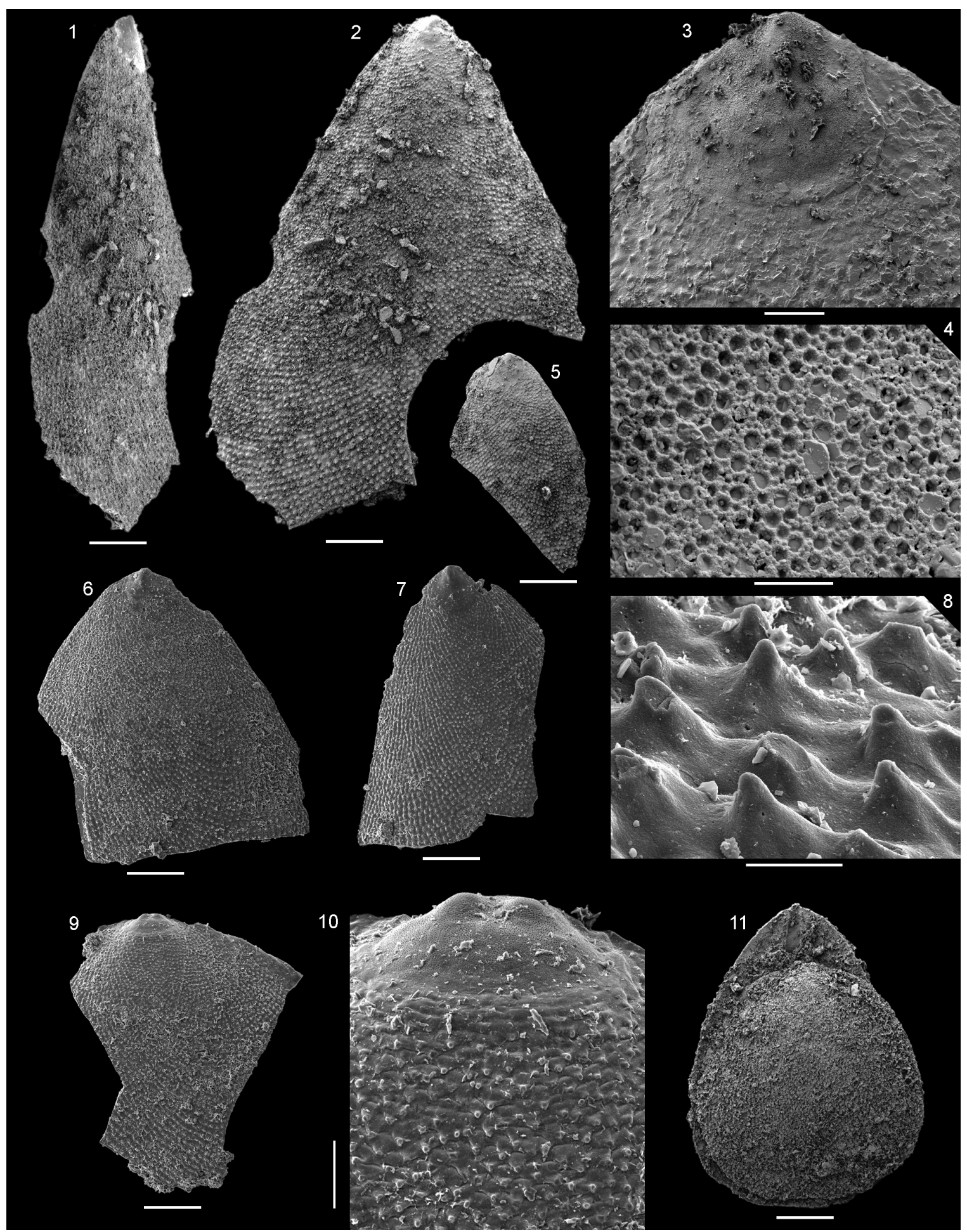

FIGURE 16. Pustulobolus triangulus n. gen et. n. sp. from the Forteau Formation, Lower shale, Mount St. Margaret of western Newfoundland. 1-2, Ventral valve NFM F-2523, sample MSM-11; 1, oblique lateral view; 2, external view. 34, Ventral valve NFM F-2524, sample MSM-11; 3, detail of larval shell; 4, detail of pitted larval shell ornament. 5, Ventral valve exterior NFM F-2525, sample MSM-11. 6, Ventral valve exterior NFM F-2526, sample MSM-5. 7-8, Ventral valve NFM F-2527, sample MSM-5; 7, exterior view; 8, detail of pustulose adult surface ornament. 9-10, Dorsal Valve NFM F-2528, sample MSM-7; 9, exterior view; 10, detail of larval shell in oblique view. 11, Conjoined shell NFM F2529, sample MSM-11, showing outline of dorsal valve and triangular ventral pseudointerarea. Scalebars equal 250 $\mu \mathrm{m}$ in figures $1-2,5-7,9$ and $11 ; 50 \mu \mathrm{m}$ in figures 3 and $10 ; 20 \mu \mathrm{m}$ in figure 8 and $5 \mu \mathrm{m}$ in figure 4. 


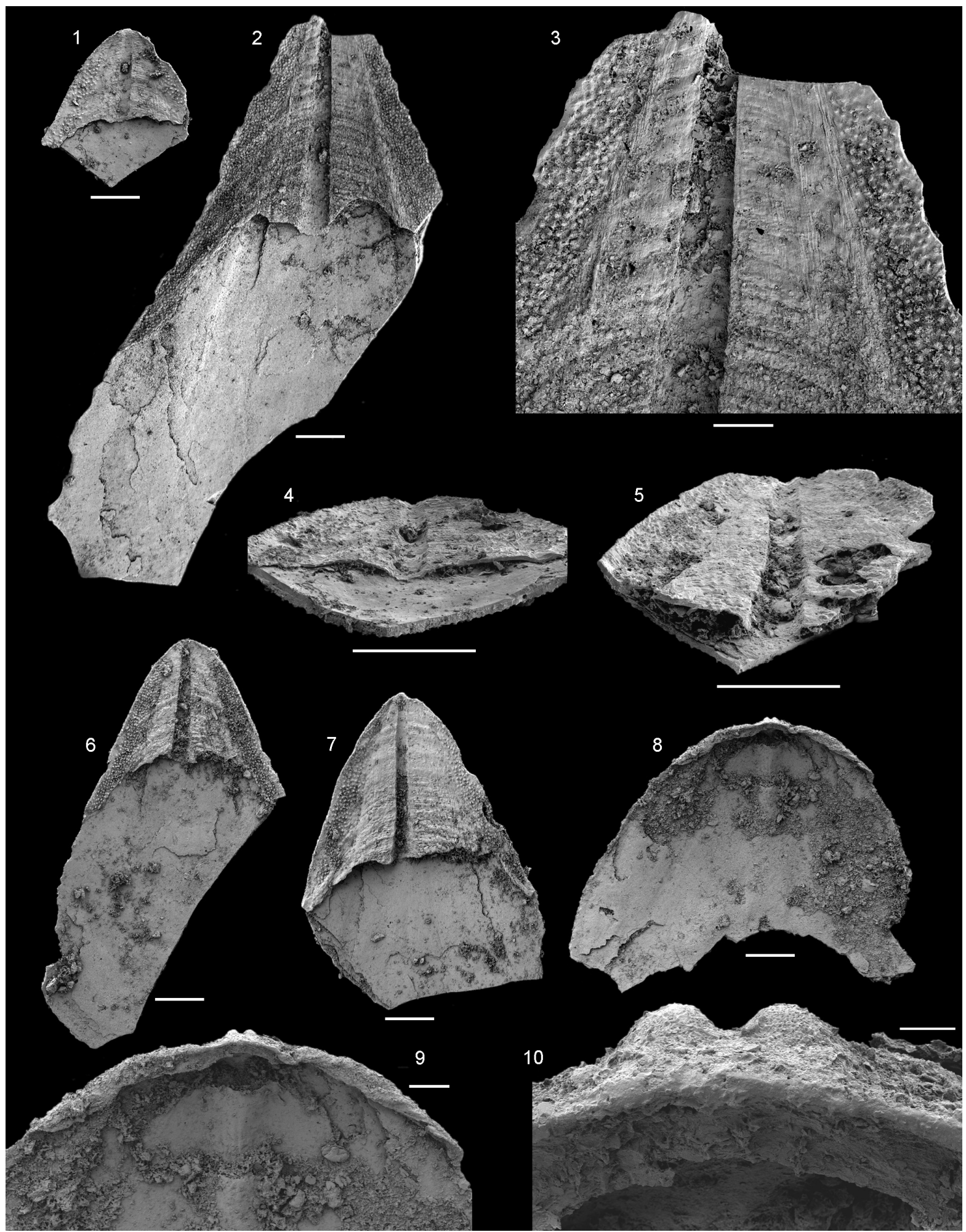

FIGURE 17. Pustulobolus triangulus n. gen et. n. sp. from the Forteau Formation, Lower shale, Mount St. Margaret of western Newfoundland, all from sample MSM-11. 1, 4, Ventral valve interior NFM F-2530, 1, interior view; 4, oblique view of interior. 2-3, Ventral valve NFM F-2531 (holotype); 2, interior view; 3, detail of ventral pseudointerarea with pustulose ornament lateral to flexure lines. 5, Ventral valve NFM F-2532, oblique view of interior showing cavities under pseudointerarea. 6, Ventral valve interior NFM F-2533. 7, Ventral valve interior NFM F-2534. 8-10, Dorsal valve NFM F-2535; 8, interior view; 9, detail of posterior margin; 10, detail of larval shell. Scalebars equal $250 \mu \mathrm{m}$ in figures 1-2 and 4-8; $100 \mu \mathrm{m}$ in figures 3 and 9; $20 \mu \mathrm{m}$ in figure 10 . 
ventral valve exterior, and the shape of the ventral pseudointerarea is more closely comparable to the linguloid genus Eoobolus, and the posteriorly extended ventral pseudointerarea is reminiscent of Lingulellotreta (see Li and Holmer, 2004) while the spine-like pustules of the adult ornament is reminiscent of Spinobolus (see Zhang et al., 2016). This combination of characters is previously unknown in any brachiopod genus, a fact that in combination with the unique presence of the adult pustulose ornament on parts of the ventral pseudointerarea, justifies the introduction of the new generic name Pustulobolus.

Although the new genus exhibits a combination of characters associated with brachiopods of several different families, the most obvious similarities are to Eoobolus and we include Pustulobolus in the family Eoobolidae. The Eoobolidae, which is characterized by having a pitted larval and a pustulose adult shell, has been suggested to be closely related to the similarly ornamented acrotheloid brachiopods, most notably the Botsfordidae (Holmer et al., 1996). As discussed above, the new genus from the Forteau Formation share characters associated with genera of both families (i.e., Eoobolus and Botsfordia). To some extent Pustulobolus represents an intermediate condition between Eoobolus and Botsfordia, and the new genus could be interpreted to fill a position in a morphological continuum between the Eoobolidae and the Botsfordidae. The similarities of Pustulobolus with Lingulotreta and Spinobolus are limited to the large ventral pseudointerarea and the spine like pustules respectively and these similarities probably reflects convergence rather than close phylogenetic relationships.

\section{Pustulobolus triangulus n. gen et. sp. Figures 16-17}

zoobank.org/A65C0BC6-B661-4F6C-9112-39273ED65D0D

1980 Lingulella cf. prisca (Poulsen, 1932); Spencer, p. 111, plate 3, figures 4-7.

Holotype. Ventral valve NFM F-2531 from sample MSM-11, Middle shale member, Forteau Formation, Mount St. Margaret, western Newfoundland (Figure 17.2) showing the characteristic triangular morphology and pustulose ornament of the ventral pseudointerarea.

Material. 36 ventral, 15 dorsal valves and a single specimen with conjoined shells from the lower shale interval of the Forteau Formation at Mount St. Margaret, western Newfoundland (MSM-4, MSM-5, MSM-7, MSM-8, MSM-11).

Diagnosis. As for genus.
Etymology. The specific name refers to the sharply pointed triangular shape of the ventral pseudointerarea.

Description. Shell dorsibiconvex and strongly inequivalved (Figure 16.11). The ventral valve has a rounded anterior margin and a sharply pointed triangular posterior margin. The umbonal angle varies from about $45^{\circ}$ to $60^{\circ}$, but the umbo is gently rounded and small specimens typically have a larger umbonal angle (up to $75^{\circ}$ ). The dorsal valve is sub-circular and the commissure is roughly planar. Larval shells sub-circular (Figure 16.4, 16.10) and ornamented by two sets of fine circular pits (Figure 16.5). Larger pits have an average diameter of $0.75-1 \mu \mathrm{m}$ and smaller pits in the spaces between the larger ones have an average diameter of $0.25-0.5 \mu \mathrm{m}$. The ventral larval shell has a single low and marginal tubercle (Figure 16.4), and the dorsal larval shell has two low tubercles (Figure 16.10). The adult shell of both valves is ornamented by pustules (diameter 4-8 $\mu \mathrm{m}$, height up to $12 \mu \mathrm{m})$ that tend to increase in size toward the anterior (Figure 16.2, 16.6-10). In some areas the pustules are developed as small spines, arranged in gently curved rows toward the anterior (Figure 16.8).

The ventral pseudointerarea is large, orthocline and triangular, representing an estimated $40 \%$ of valve length and $75 \%$ of valve width (Figure 17.1-2, 17.6-7) with a narrow, almost parallel-sided pedicle groove (width up to $100 \mu \mathrm{m}$, representing about $10 \%$ of the pseudointerarea in larger specimens). The wide propareas are divided by welldeveloped flexure lines and areas lateral to flexure lines are characterized by the adult pustulose ornament (Figure 17.3). The ventral pseudointerarea is detached from the valve floor along most of its width, but the floor of the pedicle groove remains attached, leaving a narrow, slit-like cavity under the propareas on either side of the groove (Figure 17.4). Damaged specimens show that these cavities remained open throughout ontogeny (Figure 17.5). Dorsal pseudointerarea narrow, arcuate and with a poorly defined triangular median groove (Figure 17.8-10). The propareas are wider than the median groove by about $50 \%$. In a single articulated specimen the posterior margin of the dorsal valve abuts the anterior end of the ventral pseudointerarea which projects substantially beyond the posterior margin of the dorsal valve (Figure 16.11).

Internal morphology poorly known due to valve fragmentation. Ventral valve interior with triangular lateral muscle scars inserted just under propareas (Figure 17.2, 17.6-7). Ventral visceral 
field slightly thickened and anteriorly delineated by arcuate impression of anterior muscle fields (Figure 17.6-7). Dorsal valve interior with very weakly developed median ridge and large, triangular lateral muscle fields close to the valve margin and inserted anterior to propareas (Figure 17.8).

Remarks. In her Masters thesis, Spencer (1980) compared lingulid specimens from sediments surrounding archaeocyathid patch reefs in the lower Forteau Formation (Middle shale) of southern Labrador to specimens described by Poulsen (1932) from North-East Greenland under the name Lingulella (Lingulepis) prisca Poulsen, 1932. The Greenland specimens were later referred to Eoobolus by Skovsted and Holmer (2005), who noted that the Labrador specimens illustrated by Spencer differed from the Greenland species in a number of characters, most notably the relative sizes of the pseudointerareas. Without having studied Spencer's material, Skovsted and Holmer (2005) suggested that the illustrated ventral and dorsal valves belonged to different taxa; the dorsal valves to Botsfordia caelata and the ventral valves to a new lingulid species. However, the close association of dorsal and ventral valves identical to those illustrated by Spencer in our material from the Middle shale interval at Mount St. Margaret in western Newfoundland as well as the identical ornament, and the occasional preservation of conjoined valves has led us to conclude that Spencer was correct in associating the two valve types. The resulting new species differ substantially from Eoobolus priscus, Botsfordia caelata, and all other known brachiopods and is here described as a new taxon. Unfortunately, our own collections from southern Labrador contain no specimens unequivocally referable to Pustulobolus triangulus, but the close comparison of Spencers illustrated specimens to our material leave little doubt about their identity.

Despite the distinct morphology of the ventral valves of Pustulobolus triangulus, co-occurring sub-circular dorsal valves with narrow pseudointerareas are very similar to the dorsal valves of both Botsfordia caelata and Eothele tubulus, which also occur in the Forteau Formation. The greatest difference to the dorsal valve of these species is the almost horizontal commissural plane in $P$. triangulus, which makes the dorsal valves almost flat compared to the ventrally flexed commissural plane of dorsal valves with the apex strongly depressed below the posterolateral margins in Botsfordia caelata and E. tubulus. Regardless, the similarities are so great that individual specimens may be difficult to identify, in particular as the available specimens of all three species are often fragmentary, with poorly preserved posterior margins (especially true for $E$. tubulus). However, the very distinct ventral valves of all three species are generally more common than the dorsal valves and have never been found together anywhere in the formation (although $B$. caelata and $P$. triangulus both occur at different stratigraphic intervals in the same section at Mount St. Margaret). For this reason we feel justified in associating all co-occurring dorsal and ventral valves of $P$. triangulus.

Distribution. Assemblage 1. Dyeran Stage (Unnamed Series 2, Stage 3-4), Middle shale, Forteau Formation of western Newfoundland, and possibly southern Labrador, Canada.

Superfamily ACROTHELOIDEA Walcott and Schuchert, 1908

Family BOTSFORDIIDAE Schindewolf, 1955 Genus BOTSFORDIA Matthew, 1891

Type species. Obolus pulcher Matthew, 1889

$$
\text { Botsfordia caelata (Hall, 1847) }
$$

Figure 18

* 1847 Orbicula caelata Hall, p. 290, plate 79, figure 9a-c.

1912 Botsfordia caelata (Hall); Walcott, p. 603, plate 59 , figures $1 a-q, 3 a-b$ (see also for earlier synonymy).

v 1927 Botsfordia caelata (Hall); Poulsen, p. 249, plate 14 , figures $1-2$.

1929 Botsfordia caelata (Hall); Strand, p. 340, plate 1, figure 1.

1932 Botsfordia caelata (Hall); Poulsen, p. 15, plate 2, figures 1-2.

1956 Botsfordia caelata (Hall); Lochman, p. 1370, plate 4, figures 3-6.

?1977 Botsfordia caelata (Hall); Pelman, p. 30, plate 10 , figures $1-7$.

1983 Botsfordia caelata (Hall); Goryansky and Koneva, p. 135, plate 29, figures 11-13.

1996 Botsfordia caelata (Hall); Landing and Bartowski, figures $8.20,23$.

1996 Botsfordia caelata (Hall); Holmer, Popov, and Wrona, plate 10 , figures 11,13 , possibly also figures 10, 12.

2001 Botsfordia caelata (Hall); Holmer, Popov, Koneva, and Bassett, p. 66, plate 17, figures 4-9.

2005 Botsfordia caelata (Hall); Skovsted and Holmer, p. 334 , plate 3 , figures $12-15$, plate 4 , figures 1-15.

?2010 Botsfordia caelata (Hall); Rozanov et al., p. 81 , plate 48 , figures $1-7$. 


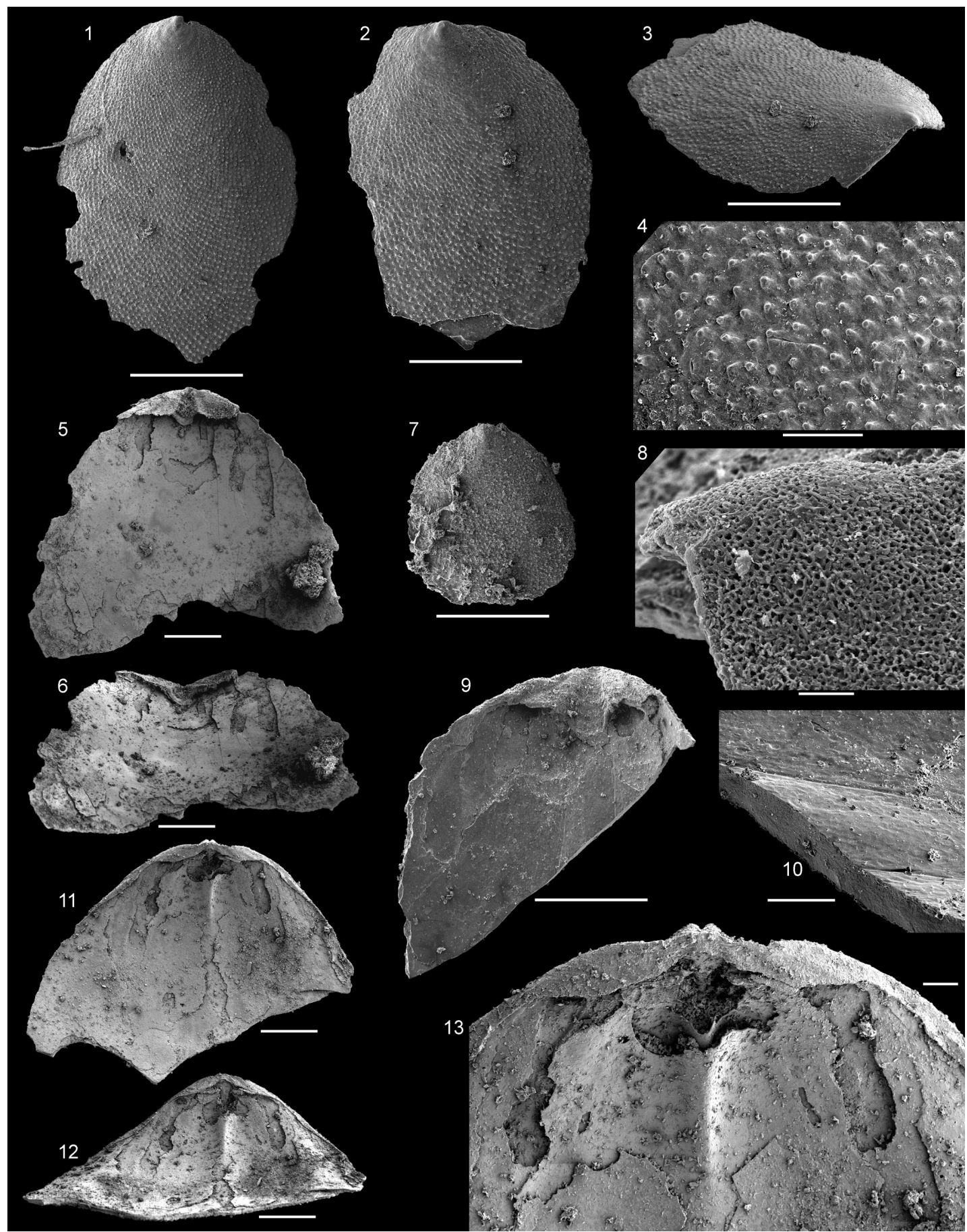

FIGURE 18. Botsfordia caelata (Hall, 1847) from the Forteau Formation of southern Labrador and western Newfoundland. 1, 8, Ventral valve NFM F-2536 from sample ICS1565; 1, exterior view; 8, detail of larval shell with pitted ornament. 2-4, Ventral valve NFM F-2537 from Devils Cove member, East Castor Pond, sample ECP-03; 2, external view; 3, oblique posterolateral view; 4, detail of pustulose adult shell ornament. 5-6, Ventral valve NFM F-2538 from Devils Cove member, East Castor Pond, sample ECP-03; 5, interior view; 6, oblique interior view. 7, Ventral valve exterior NFM F-2539 from Devils Cove member, East Castor Pond, sample ECP-03. 9-10, Ventral valve NFM F-2540 from Devils Cove member, East Castor Pond, sample ECP-03; 9, interior view; 10, detail interior surface in oblique view showing imprints of pedicle nerves. 11-13, Dorsal valve NFM F-2541 from Devils Cove member, East Castor Pond, sample ECP-03; 11, interior view; 12, oblique interior view; 13, detail of internal surface with dorsal pseudointerarea and posterolateral muscle scars. Scalebars equal $500 \mu \mathrm{m}$ in figures 1-3, 5-7, 9 and 11-12; $100 \mu \mathrm{m}$ in figures 4 , 10 and $13 ; 10 \mu \mathrm{m}$ in figure 8 . 
?2016 Botsfordia caelata (Hall); Ushatinskaya and Korovnikov, p. 452, plate 3, figures 1-10.

Holotype. Not designated (see Walcott, 1912, p. 821).

Material. 49 ventral, 48 dorsal valves, and a single specimen with conjoined valves from the Middle shale of the Forteau Formation of southern Labrador (FC1-3, FC1-4, FC1-5, FC1-7, FC2-5, FC2-6, FC2-7, FCX, ICS1553, ICS1562, ICS1565, ICS1575, ICS1581) and the Devils Cove member of western Newfoundland (MSM-2, MSM-3, ECP1, ECP-3, ICS 1520).

Diagnosis. See Skovsted and Holmer (2005), p. 336.

Description. The material of Botsfordia caelata from the Forteau Formation is invariably fragmentary, but aspects of the external morphology are sometimes well preserved. The ventral valve is convex with catacline pseudointerarea with triangular pedicle groove and raised propareas (Figure $18.5-6,18.9)$. Dorsal valve gently convex with marginal umbo, a strongly ventrally deflected commissural plane along the posterior margin, curved pseudointerarea with a wide, triangular median groove (Figure 18.11-13). Ventral larval shell subcircular with a single central tubercle (Figure 18.1$2,18.8$ ) and ornamented by fine pits with a diameter of 0.7 to $1 \mu \mathrm{m}$. Adult shell pustulose, with pustules of 8-14 $\mu \mathrm{m}$ in diameter, typically increasing in size anteriorly.

Ventral valve interior with a slightly thickened visceral area with elongate posterolateral and arcuate central muscle fields and divergent impressions of pedicle nerves (Figure 18.5-6, 18.9-10). Dorsal valve interior with a low median ridge and deeply impressed posterolateral muscle fields (Figure 18.11-13).

Remarks. The morphology of Botsfordia caelata is described in detail by Skovsted and Holmer (2005), but the Forteau Formation material adds new morphological information, in particular the morphology of the ventral larval shell and the finely pitted larval micro-ornament. The ventral valves of $B$. caelata differ from ventral valves of Pustulobolus triangulus by the smaller and non-orthogonal ventral pseudointerarea and from Eothele tubulus by the presence of a ventral pseudointerarea and the lack of a pedicle foramen throughout ontogeny. The dorsal valves of $B$. caelata are more similar to the dorsal valves of $P$. triangulus and $E$. tubulus but differ from $P$. triangulus by the shorter dorsal pseudointerarea and the ventrally deflected commissural plane, and from $E$. tubulus by the narrower pseudointerarea with propareas slightly wider than the median groove.

Botsfordia caelata is very common in eastern Laurentia (Walcott, 1912; Lochman, 1956; Skovsted and Holmer, 2005) and is also known from Norway (Strand, 1929) and Kazakhstan (Gorjansky and Koneva, 1983; Holmer et al., 2001). The species has also been reported from the Siberian platform (Pelman, 1977; Rozanov et al., 2010; Ushatinskaya and Korovnikov, 2016). The Siberian shells are very similar to the Laurentian specimens investigated by us but appear to differ in the more circular shape of the ventral valves and in the the smaller ventral and dorsal pseudointerareas as well as the less pronounced ventral flexing of the dorsal valve. For this reason we only include the Siberian material as questionably belonging to $B$. caelata.

In the Forteau Formation, Botsfordia caelata occurs exclusively in shallow water carbonates in the lower part of the formation deposited during the TST of the sequence and always in association with archaeocyathid buildups (i.e., Middle shale at Fox Cove in southern Labrador and scattered archaeocyathid clasts in the Devils Cove member at the Mount St. Margaret and ECP-sections in western Newfoundland). As with Pustulobolus triangulus and Eothele tubulus, the distributional pattern is based on identification of ventral valves only, as the dorsal valves of all three species are considered to be too similar to be clearly identifiable on their own unless perfectly preserved specimens are available. The occurrence in shallow water carbonates in the Forteau Formation may seem at odds with the presence of $B$. caelata in relatively deep water sediments elsewhere in eastern Laurentia (i.e., Taconic Allochthon [Lochman, 1956] and the Bastion Formation of North-East Greenland [Skovsted and Holmer, 2005]). However, in these cases the described specimens occur in event beds in distal shelf or continental slope settings and may have been derived from more near-shore environments. In Norway B. caelata occur in sandy limestone at Tømten (Strand, 1929) that together with the occurrences in Kazakhstan in shallow water carbonates (Holmer et al., 2001), seems to corroborate the distributional pattern of the species in the Forteau Formation. However the occurrence of possible specimens of $B$. caelata in the Sinsk biota of Siberia in an open marine setting with dysaerobic bottom waters (Ivantzov et al., 2005) is clearly opposite to the pattern identified in the Forteau Formation and invites further study of both the tax- 

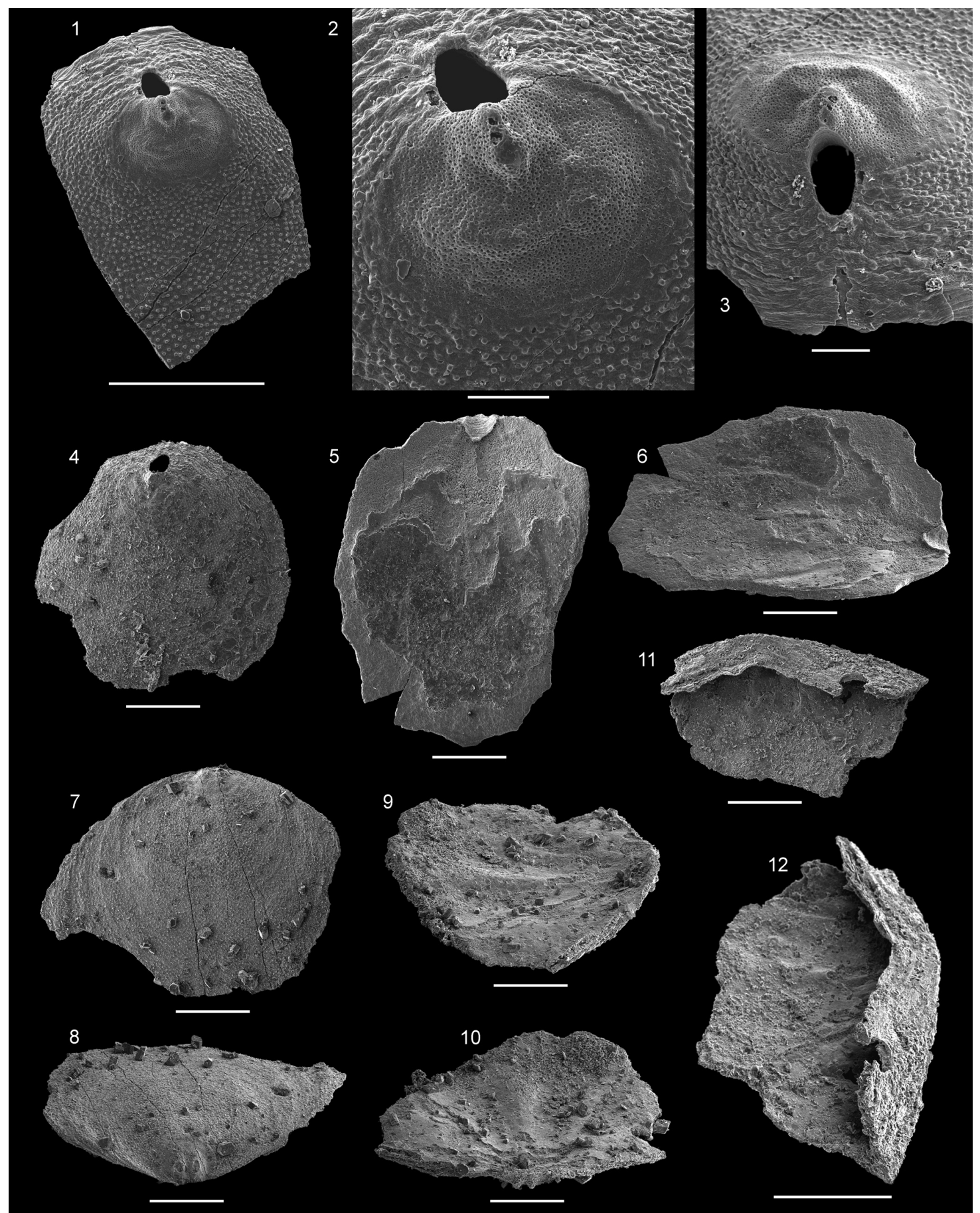

FIGURE 19. Eothele tubulus Ushatinskaya in Voronova et al., 1987 from the Forteau Formation of western Newfoundland. 1-3, Ventral valve NFM F-2575 from Deer Arm Limestone, sample GM07-5-1; 1, external view; 2, detail of larval shell showing pitted larval and pustulose adult shell ornament; 3, detail of posterior margin in oblique view showing oval opening of pedicle tube. 4, Ventral valve NFM F-2573 from Deer Arm Limestone, sample GM07-4-1. 56, Ventral valve NFM F-2568 from Deer Arm Limestone, sample GM07-3-1; 5, internal view; 6, oblique view showing median tongue and imprints of vascula lateralia. 7-8, Dorsal valve NFM F-2576 from Deer Arm Limestone, sample GM07-5-1; 7, external view; 8, oblique posterior view. 9-10, Dorsal valve NFM F-2521 from Deer Arm Limestone, sample GM07-5-1; 9, oblique lateral view; 10, oblique posterior view. 11-12, Dorsal valve NFM F-2569 from Mackenzie Mill member, sample GM07-2-1; 11, internal view showing dorsal pseudointerarea; 12, oblique lateral view. All scalebars equal $500 \mu \mathrm{m}$ except in figures 2-3 that equals $100 \mu \mathrm{m}$. 
onomy of the Siberian shells and the distributional pattern of $B$. caelata in other areas of east Laurentia.

Distribution. Assemblage 1, Devils Cove member and Middle shale, Forteau Formation of southern Labrador and western Newfoundland. Cambrian Series 2, Stage 4 of eastern Laurentia (New York State, Vermont, North-East Greenland), Norway, Kazakhstan, and possibly Siberia.

Family ACROTHELIDAE Schuchert, 1893 Genus EOTHELE Rowell, 1980

Type species. Eothele spurri Rowell, 1980.

Eothele tubulus Ushatinskaya in Voronova, Drosdova, Esakova, Zhegallo, Zhuravlev,

Rozanov, Sayutina, and Ushatinskaya, 1987

Figure 19

*1987 Eothele tubulus Ushatinskaya in Voronova, Drosdova, Esakova, Zhegallo, Zhuravlev, Rozanov, Sayutina, and Ushatinskaya, p. 50, plate 22, figures 1-6, plate 23, figure 3 .

2007 Eothele sp. Skovsted and Peel, figure 2C.

2010 Eothele tubulus Ushatinskaya in Voronova et al.; Skovsted and Peel, p. 760, figure 4.14.19.

2016 Eothele tubulus Ushatinskaya in Voronova et al.; Ushatinskaya and Korovnikov, p. 460, figure $2 a-i$, figure $3 f$.

Holotype. GSC N 90245 (Voronova et al., 1987, plate 22, figure 1), from sample N42, collected from unnamed rock unit above Sekwi Formation, $10 \mathrm{~m}$ below locality GSC 95527, Mackenzie Mountains, Northwest Territories, Canada.

Material. 244 ventral and 33 dorsal valves from the Forteau Formation of the Bonne Bay area, western Newfoundland (GM07-2-1, GM07-3-1, GM07-4-1, GM07-5-1, GM11-4-2, GM11-5-E, GM11-6, GM116-11, GM11-6-13, GM11-9A-2, GM11-9A-8T, GM11-9A-9, GM11-9A-10, GM11-9A-12, GM11-14, GM11-14-2, GM11-14A-5, GM11-14C, GM11-14G1, GM11-14G-3B, GM11-14G-C, ICS1518, ICS1519, ICS1421, JSP1982-01).

Diagnosis. (Emended from Skovsted and Peel, 2010). Species of Eothele with elongate lenticular pedicle foramen and reduced internal pedicle tube. Differs from $E$. spurri and $E$. granulata by the smaller pedicle opening, its lenticular shape, the short internal pedicle tube, the less pronounced anterior flexing of the ventral valve and the less pronounced ventrally directed flexure of the dorsal umbo.

Description. Sub-circular, dorsibiconvex shell. Ventral valve low cone-shaped with procline, slightly convex pseudointerarea and concave ante- rior slope (Figure 19.1). Pedicle foramen lenticular, situated on the ventral pseudointerarea, just below the ventral larval shell (Figure 19.2-3). Dorsal valve sub-circular with larval shell at posterior margin (Figure 19.7) and ventrally deflected commissural plane of the posterior margin (Figure 19.8). Dorsal pseudointerarea arcuate and raised substantially above valve floor (Figure 19.11-12), with wide, triangular but poorly defined median groove. Ventral larval shell with one high tubercle at posterior margin and two low tubercles anteriorly (Figure 19.13). Dorsal larval shell with two high tubercles close to posterior margin (Figure 19.8). Larval shells finely pitted (diameter of pits 2-3 $\mu \mathrm{m}$; Figure 19.2), adult shell pustulose with pustules increasing in diameter away from the apex (diameter 7-10 $\mu \mathrm{m}$; Figure 19.1-3).

Ventral valve interior with rounded anterior muscle fields bisected by elongate and slightly thickened central lobe of visceral area anterior to pedicle tube (Figure 19.5). Arcuate impressions of vascula lateralia are present lateral to anterior muscle fields (Figure 19.6). Dorsal valve interior with low median ridge with large central muscle scars on either side (Figure 19.9-10). Faint impressions of vascula lateralia and umbonal muscle scars inserted beneath dorsal pseudointerarea.

Remarks. Eothele tubulus was originally described from the lower Cambrian of the Mackenzie Mountains of Northwest Territories in Canada (Voronova et al., 1987), but the species was recently redescribed based on collections from the Kinzers Formation of Pennsylvania by Skovsted and Peel (2010), who also included a few specimens from the Forteau Formation of western Labrador illustrated by Skovsted and Peel (2007) in the species. The new collections from Gros Morne now available allow us to confirm the presence of $E$. tubulus in the Forteau Formation and complement the description by Skovsted and Peel (2010) with new data, in particular the morphology of the dorsal valve but also aspects of the ventral valve interior. As outlined by Skovsted and Peel the species differ from other species in the genus (i.e. E. spurri, E. granulata) by the lower umbonal region and more evenly lens-shaped pedicle foramen and the short pedicle tube. The dorsal valve also differs by the less pronounced umbonal flexing.

Eothele tubulus was recently reported from the Toyonian to Amgan stages of the Siberian Platform (Ushatinskaya and Korovnikov, 2016). Although fragmentary and slightly younger than the material from Laurentia, the illustrated specimens from Siberia are remarkably similar to the material 


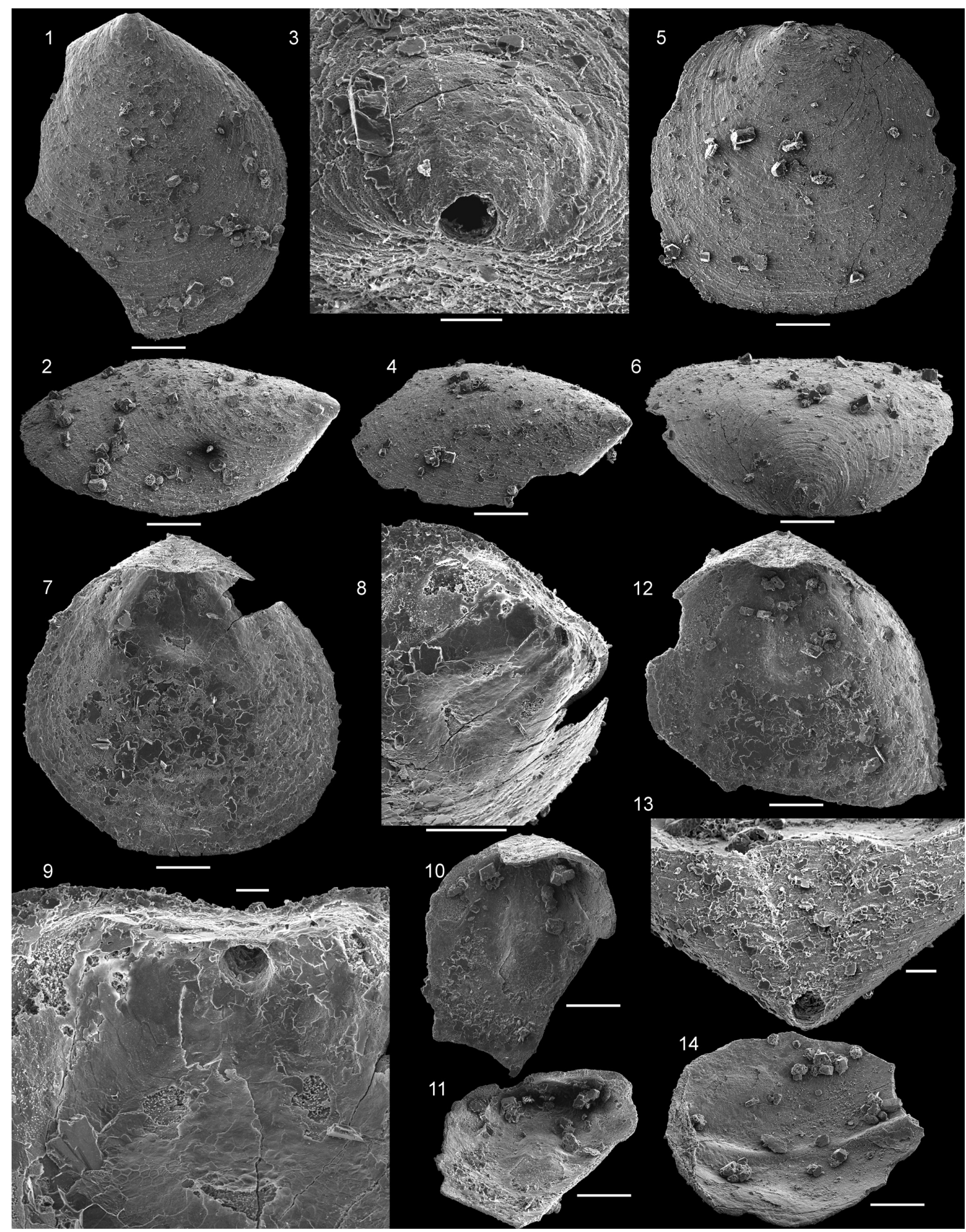

FIGURE 20. Acrothyra bonnia n. sp. from the Forteau Formation of western Newfoundland, Deer Arm Limestone, sample GM07-5-1. 1-3, Ventral valve NFM F-2559; 1, external view; 2, oblique lateral view; 3, detail of larval shell and pedicle foramen. 4, Ventral vave NFM F-2560, oblique lateral view. 5-6, Dorsal valve NFM F-2561; 5, external view; 6, oblique posterior view. 7-9, Ventral valve NFM F-2562 (Holotype), 7, internal view; 8, oblique lateral view of posterior margin and apical process; 9, detail of oblique anterior view of shell interior showing internal opening of pedicle foramen and muscle scars lateral to apical process. 10-11, Ventral valve NFM F-2563, 10, internal view; 11, oblique anterior view. 12-13, Ventral valve NFM F-2564, 12, internal view; 13, detail of ventral pseudointerarea in oblique posterior view showing triangular intertrough. 14, Dorsal view NFM F-2565, oblique lateral view showing low median ridge. All scalebars equal $250 \mu \mathrm{m}$ except in figures 3, 9 and 13 that equals $100 \mu \mathrm{m}$. 
from Newfoundlan described herein and likely belong to the same species.

Distribution. Assemblage 3, Mackenzie Mill member, Forteau Formation of the Bonne Bay area, western Newfoundland. Cambrian Series 2, Stage 4 (Dyeran Stage) of North-West Territories and Pennsylvania.

Order ACROTRETIDA Kuhn, 1949

Superfamily ACROTRETOIDEA Schuchert, 1893

Family ACROTRETIDAE Schuchert, 1893

Genus ACROTHYRA Matthew, 1901

Type species. Acrotreta proavia Matthew, 1899.

\section{Acrothyra bonnia n. sp.}

Figure 20

zoobank.org/C1FBC30E-AE3A-4611-B123-D74EE067EC76

Holotype. Ventral valve NFM F-2562 from the Forteau Formation of western Newfoundland, Deer Arm Limestone, sample GM07-5-1 (Figure 20.7-9). Material. 114 ventral and 52 dorsal valves from the Forteau Formation of the Bonne Bay area, western Newfoundland (GM07-2-1, GM07-4-1, GM07-5-1, GM11-5-E, GM11-8A-1, GM11-14G-C, ICS 1518, ICS 1519, JSP1982-01).

Diagnosis. Species of Acrothyra with short apsacline ventral pseudointerarea with a triangular intertrough. Ventral valve interior with elongate apical process reaching to about $1 / 3$ of valve length and with a triangular depression but without apical pits. Differ from A. proavia (Matthew, 1899) and $A$. signata Matthew, 1902 by the much shorter ventral pseudointerarea, from $A$. sera Matthew, 1902 and A. comleyensis Cobbold, 1921 by the apsacline ventral pseudointerarea and from $A$. minor Walcott, 1905 by the straight and slightly longer ventral pseudointerarea and the more rounded valve outline.

Etymology. From the occurrence of the species in the vicinity of Bonne Bay in western Newfoundland.

Description. Ventribiconvex acrotretid shells. Ventral valve sub-triangular in outline and low coneshaped (Figure 20.1-2, 20.7). Greatest width at about mid-valve. Ventral pseudointerarea apsacline, relatively short and inclined by about $75^{\circ}$ with a triangular intertrough expanding toward the posterior margin (Figure 20.2, 20.4, 20.6, 20.12-13). Pedicle foramen situated just below apex and not completely enclosed within larval shell (Figure 20.3). Dorsal valve rounded sub-rectangular in outline with marginal umbo and greatest width anterior of mid-valve (Figure 20.5-6). Dorsal pseudointerarea with a wide, triangular median groove, and narrow propareas (Figure 20.14). Exterior surface of both valves ornamented by fine concentric fila (Figure 20.1, 20.3, 20.5).

Ventral valve interior with low, tongue-like apical process reaching to about $1 / 3$ of valve length and expanding anteriorly (Figure 20.7-12). The crest of the process has a shallow elongated triangular depression connected to pedicle foramen by a narrow channel (Figure 20.8). A small arcuate muscle scar is present at the anterior termination of the apical process, and two rounded umbonal muscle scars are situated at the middle of its flanks (Figure 20.9). No apical pits are present. Posterolateral muscle scars are present close to the lateral terminations of the pseudointerarea (Figure 20.12). Dorsal valve interior poorly known but with a long median septum increasing in height slightly anterior of mid valve and rounded cardinal muscle scars close to the posterolateral margin (Figure 20.14).

Remarks. This species is referred to Acrothyra based on the short, apsacline ventral pseudointerarea. It differs from Aphelotreta Rowell, 1980 by the long, tongue-like apical process of the ventral valve and the long dorsal median septum. Acrothyra bonnia n. sp. differs from all other species of the genus by the rounded triangular ventral valve morphology with a relatively short and apparently straight ventral pseudointerarea. The most obvious similarities are to $A$. minor from the middle Cambrian of Idaho (Walcott, 1905; Rowell, 1966), but the new species differ both in the shape of the valves and in the development of the pseudointerarea. Acrothyra bonnia is the currently oldest known of the established species of the genus.

Distribution. Assemblage 3. Cambrian Series 2, Stage 4, Forteau Formation of the Bonne Bay area, western Newfoundland, Canada.

Genus HADROTRETA Rowell, 1966

Type species. Acrotreta primaea Walcott, 1902.

Hadrotreta taconica (Walcott, 1887)

Figure 21

1887 Linnarssonia taconica Walcott, p. 189, 190, plate 1, figure 18-18d.

1912 Acrotreta sagittalis taconica (Walcott). Walcott, p. 707,708 , plate 71 , figure $1-10$ (includes synonymy).

1956 Acrotreta taconica (Walcott). Lochman, p. 1370 , plate 3 , figures $9-12$.

2002 Linnarssonia taconica Walcott. Landing, Geyer, and Bartowski, p. 298, figure 7-1-7.9.

?2005 Vandalotreta sp. Skovsted and Holmer, p. 338 , text-figure $2 \mathrm{~A}-\mathrm{E}$. 


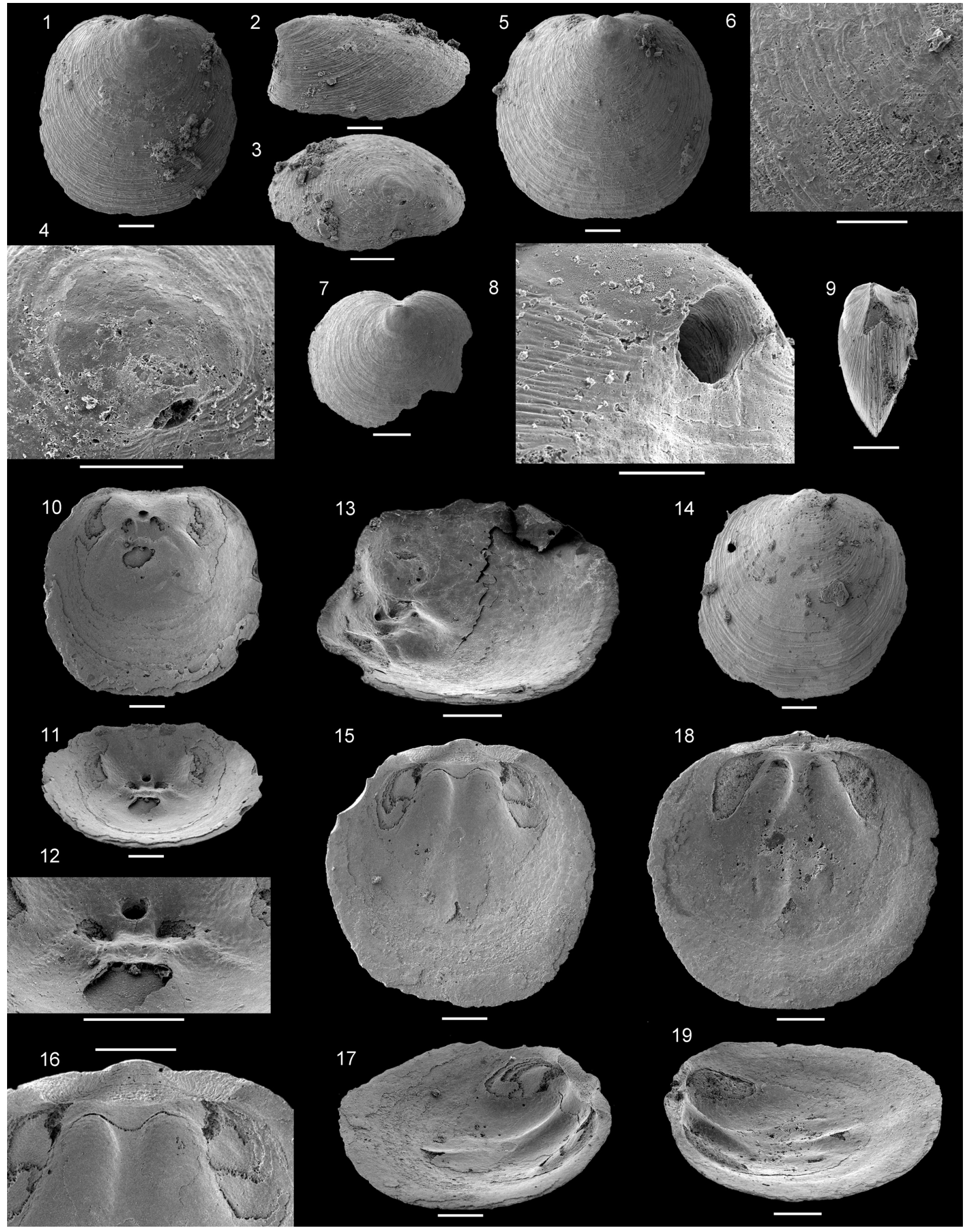


Holotype. Ventral valve USNM 52163b, from lower Cambrian limestone south of North Granville, Washington Co. New York State, USA (Walcott, 1887, plate 1, figure 18b; Walcott, 1912, plate 71, figure 1c).

Diagnosis. Species of Hadrotreta with ventribiconvex, sub-circular to sub-rectangular shell. Ventral pseudointerarea with deep intertrough. Dorsal pseudointerarea $50 \%$ of valve width, with wide triangular median groove. Ventral interior with apical pits lateral and anterior of pedicle tube, posterior of apical process. Dorsal interior with very weak, forked median septum, almost lacking median buttress. Differ from Hadrotreta primaea Walcott, 1902 by the ventral apical pits anterior to the pedicle foramen and lack of boss-like termination of dorsal median ridge. Differ from $\mathrm{H}$. trichristiorum Popov et al., 2015 by the larger dorsal pseudointerarea and deeper ventral intertrough.

Material. 589 ventral, 712 dorsal valves and 10 conjoined shells from the Forteau Formation of southern Labrador and western Newfoundland, both west of the Long Range Mountains and in the Bonne Bay area (GM07-2-1, GM07-3-1, GM07-41, GM11-1-6, GM11-1-6A, GM11-1-6C, GM11-18C, GM11-1-9, GM11-1-10T, GM11-1-14, GM11-115, GM11-4-2, GM11-6, GM11-6-11, GM11-6-13, GM11-9A-9, GM11-9A-10, GM11-11-3, GM11-14, GM11-14A-5, GM11-14A-7, GM11-14-C, GM1114G-1, GM11-14G-2, GM11-14G-B, GM11-14G3B, GM11-14G-C, ECP-1, ECP-3, MSM-1, MSM-2, MSM-3, MSM-4, MSM-7, MSM-8, FC1-5, FC1-6, FC1-7, FC2-2a, FC2-4, FC2-9, FCX, F-1, ICS1545, ICS1553, ICS1560, ICS1562, ICS1565, ICS1575, ICS1576, ICS1577, ICS1578, ICS 1519, ICS1421, JSP1982-01)

Description. Ventribiconvex acrotretid shell. Ventral valve cone-shaped with rounded or sub-rectangular outline, greatest width about mid-valve (Figure 21.1, 21.5, 21.7, 21.10). Ventral pseudointerarea catacline or weakly procline (Figure 21.2,
21.9). Ventral pseudointerarea with deeply incised intertrough, slightly expanding towards posterior margin (Figure 21.3, 21.7). Ventral larval shell convex and circular (Figure 21.4). Pedicle foramen sub-circular, situated at posterior margin of larval shell (Figure 21.8). Dorsal valve sub-circular with greatest width slightly posterior to mid valve, slight anterior sulcus (Figure 21.14-19). Dorsal larval shell marginal, slightly overhanging posterior margin (Figure 21.14). Narrow, orthocline dorsal pseudointerarea representing about $50 \%$ of valve width, with wide, triangular median groove and well defined propareas (Figure 21.15-18). Larval shell ornamented by fine pits and post larval shell by fila, sometimes with nick points (Figure 21.6, 21.8).

Ventral valve interior with boss-like apical process situated slightly anterior to internal tube of pedicle foramen (Figure 21.10-13). Deep apical pits are situated lateral to and slightly anterior of the pedicle tube, between the pedicle tube and the apical process (Figure 21.12-13). The apical process is flanked laterally by arcuate impressions of the vascula lateralia extending from the apical pits (Figure 21.13). Well developed ventral cardinal muscle scars are situated lateral to the vascula lateralia, at the lateral margins of the ventral pseudointerarea (Figure 21.10-11). Dorsal interior with strongly impressed cardinal muscle fields representing about $20 \%$ of valve length (Figure 21.15, 21.18). Dorsal median septum poorly developed, except at its posterior termination (Figure 21.17, 21.19). Almost no median buttress at all. The median septum is flanked by two, very weakly expressed ridges apparently diverging from the main septum (Figure 21.18). Elongate anterocentral muscle scars present close to the terminations of the lateral ridges of the median septum (Figure 21.18). Impressions of diverging vascula media present at the termination of the median buttress (Figure 21.17).

FIGURE 21 (previous page). Hadrotreta taconica (Walcott, 1887) from the Forteau Formation of southern Labrador and western Newfoundland. 1-4, Ventral valve NFM F-2542 from sample ICS1577; 1, external view; 2, oblique lateral view; 3, oblique posterolateral view; 4, detail of apex showing larval shell. 5-6, Ventral valve NFM F-2543 from sample ICS1577; 5, external view; 6, detail of adult shell ornament. 7, Ventral valve NFM F-2544 from sample ICS1565 in external view. 8, Ventral valve NFM F-2545 from sample ICS1565, detail of posterior margin in oblique lateral view showing position of pedicle foramen at junction between larval and adult shell. 9, Conjoined shell NFM F-2546 ICS1575 in lateral view. 10-12, Ventral valve NFM F-2547 from sample ICS1545; 10, internal view; 11, oblique anterior view; 12, detail of apical process, pedicle foramen and apical pits. 13, Ventral valve NFM F-2548 from sample ICS1553; oblique lateral internal view. 14, Dorsal valve NFM F-2549 from sample ICS1548; external view. 15-17, Dorsal valve NFM F-2550 from sample ICS1553; 15, internal view; 16, detail of posterior margin showing dorsal pseudointerarea; 17, oblique lateral view. 18-19, Dorsal valve NFM F-2551 from sample ICS1575; 18, internal view; 19, oblique lateral view. Scalebars equal $200 \mu \mathrm{m}$ in figures 1-3, 5, 7 and 9-19, $100 \mu \mathrm{m}$ in figures 4 and 6 and $50 \mu \mathrm{m}$ in figure 8 . 
Remarks. The majority of acrotretid specimens from the Forteau Formation belong to Hadrotreta taconica (Walcott, 1887). This species is referred to Hadrotreta based on the oval pedicle foramen situated outside the larval shell, the boss-like apical process of the ventral valve, the presence of deep apical pits lateral to the internal pedicle tube and the low, forked dorsal median ridge (Holmer and Popov, 2000). Similar material from the Taconic allochthon at Ville Guay, Quebec is described by Landing et al. (2002) as Linnarssonia taconica Walcott, 1887. Landing et al. (2002) appear to have based (erroneously) the reference of this species to Linnarssonia on the suggested presence of the apical foramen inside the larval shell. However, the only illustrated specimen with ventral external apical surface preserved (Landing et al., 2002, figure 7.3) appear to show an apical foramen situated on the slope of the ventral pseudointerarea, at the margin of the larval shell. Like Hadrotreta, Linnarssonia has the apical foramen between the larval and adult shell but differ from Hadrotreta in the less pronounced apical pits on the ventral valve interior, the vestigial propareas of the dorsal pseudointerarea, the more closely arranged cardinal muscle scars and the higher and shorter dorsal median ridge (Holmer and Popov, 2000; Peel et al., 2016). The acrotretid specimens described by Landing et al al., 2002 appear to belong to the same species of Hadrotreta as the specimens from the Forteau Formation described here.

Hadrotreta taconica differ from the type species, H. primaea Walcott, 1902 from the Pioche Shale of the Great Basin by the position of the ventral apical pits anterior to the pedicle foramen and the less pronounced, boss-like anterior termination of the dorsal median ridge (Rowell, 1980). The species differ from $H$. trichristiorum Popov et al., 2015 by the larger dorsal pseudointerarea and larger dorsal muscle scars as well as the more well-defined ventral intertrough (Popov et al., 2015). Hadrotreta taconica is a common species in the late early Cambrian (Cambrian Stage 4) of eastern Laurentia with specimens reported from multiple localities in the Taconic Allochthons (Walcott, 1912; Lochmann, 1956; Landing et al., 2002). Poorly preserved acrotretid specimens from the Ella Island Formation of North-East Greenland, described by Skovsted and Holmer (2005) as Vandalotreta sp., may also belong to $H$. taconica based on the position of apical pits lateral to the internal pedicle tube of ventral valves (Skovsted and Holmer, 2005, text-figure 2D) and may further extend the range of the species. In the Forteau Formation, Hadrotreta taconica is one of the most numerous of all brachiopod species with over 1000 shells recovered. Hadrotreta taconica has a very broad range in the Forteau Formation and is present in large numbers, both in the vicinity of archaeocythan reefs in southern Labrador, in the Middle shale at Mount St. Margaret and in the argillaceous facies of the Bonne Bay area where it may co-occur with Acrothyra bonnia (assemblages 1 and 3).

Distribution. Assemblages 1 and 3. Cambrian Series 2, Stage 4, Devils Cove, Middle shale and Mackenzie Mill members, Forteau Formation of southern Labrador and western Newfoundland, west of the Long Range Mountains, and the Bonne Bay area, Canada. Cambrian Stage 4 of New York State and Vermont and British Columbia.

\section{Hadrotreta sp. \\ Figure 22}

Material. Four specimens from the lower patch reef complex of southern Labrador and the Devils Cove member at Mount St. Margaret in western Newfoundland, west of the Long Range Mountains (MSM-3, ICS1553, ICS1577).

Description. A handful of acrotretid ventral valves of presumed sub-circular outline, no specimen preserves the complete margin of the shell and its shape is difficult to determine (Figure 22.2-3). The pedicle foramen is situated at the margin of the larval shell and drop-shaped (Figure 22.4). The ventral pseudointerarea is procline with a narrow, parallell-sided intertrough (Figure 22.1, 22.3). The internal morphology is revealed in a single specimen showing a large apical process anterior of the pedicle tube, deep apical pits lateral to the pedicle tube and deeply impressed, straight vascula lateralia (Figure 22.5-6). A narrow central ridge extends anteriorly from the apical process and on each side three smaller ridges are present between the central ridge and the vascula lateralia. The ornament of the larval shell unknown and the adult shell is ornamented by fine fila (Figure 22.4).

Remarks. A small number $(\mathrm{N}=4)$ of ventral valves of an acrotretid brachiopod from the Devils Cove member at Mt. St. Margaret and the lower patch reef complex of southern Labrador differ from Hadrotreta taconica by the strongly procline ventral pseudointerarea with a narrow intertrough, the central ridge extending from the apical process and the position of the apical pits lateral to the internal opening of the pedicle tube. It was not possible to identify the associated dorsal valve of this species. Due to the small number of specimens and the lack of knowledge of the dorsal valve morphology, this 


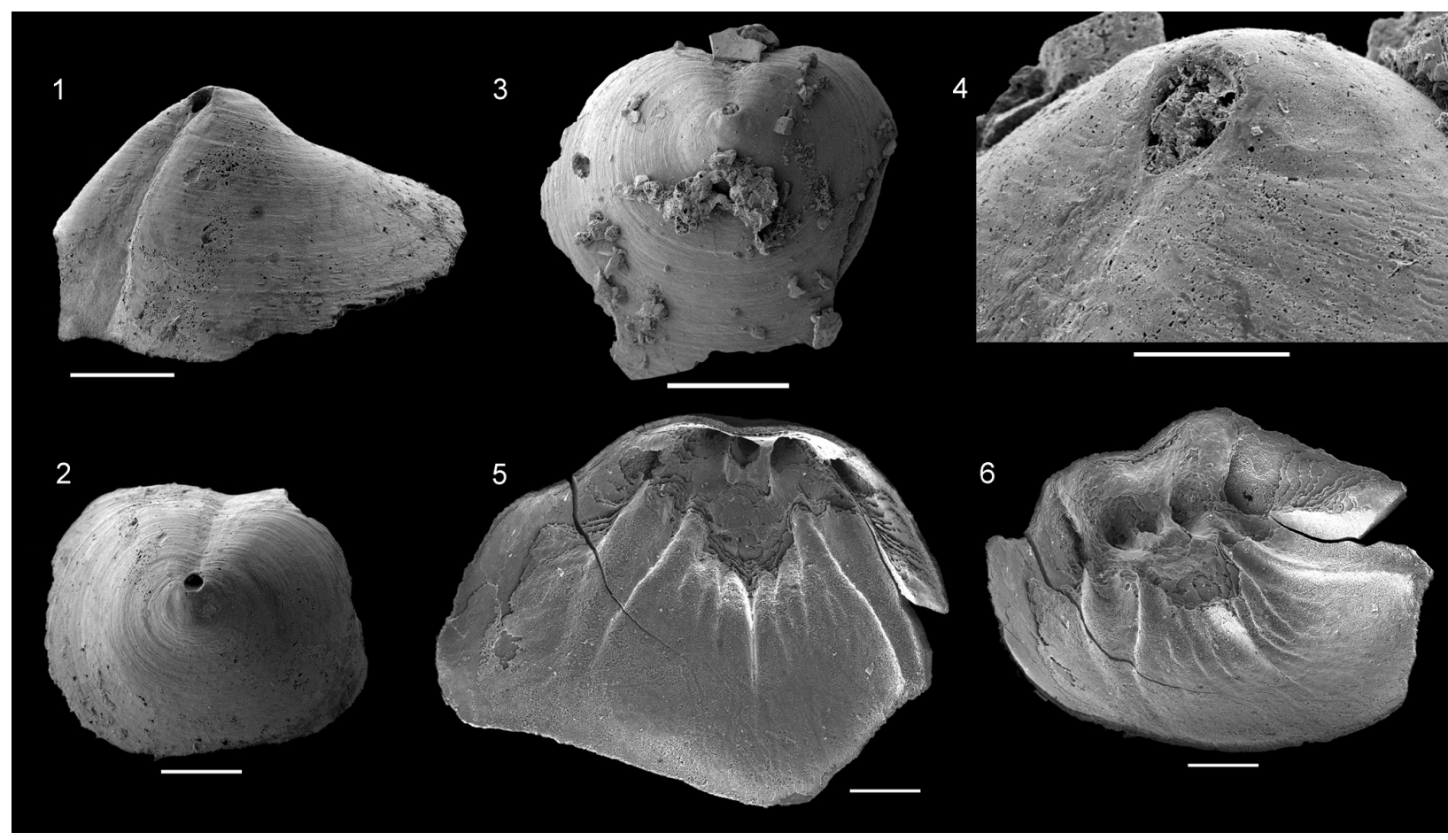

FIGURE 22. Hadrotreta sp. from the Forteau Formation of southern Labrador and western Newfoundland. 1-2, Ventral valve NFM F-2552 from sample ICS1553; 1, oblique posterior view showing procline pseudointerarea; 2, external view. 3-4, Ventral valve NFM F-2553 from sample ICS1577; 3, external view; 4, detail of larval shell with drop-shaped pedicle foramen. 5-6, Ventral valve NFM F-2554 from Lower shale, Mount St. Margaret, sample MSM-3; 5, internal view showing vascula lateralia and apical process; 6 , oblique anterior view showing apical pits and internal opening of pedicle foramen. Scalebars equal $500 \mu \mathrm{m}$ in figure 3, $200 \mu \mathrm{m}$ in figures 1-2, 5-6 and $100 \mu \mathrm{m}$ in figure 4

species is left under open nomenclature as Hadrotreta sp.

Distribution. Assemblage 1, Devils Cove member and Middle shale, Forteau Formation of southern Labrador and western Newfoundland.

Class PATERINATA Williams, Carlson, Brunton, Holmer, and Popov, 1996

Order PATERINIDA Rowell, 1965

Superfamily PATERINOIDEA Schuchert, 1893

Family PATERINIDAE Schuchert, 1893

Figure 23

Remarks. The brachiopod fauna of the Forteau Formation contain two distinct paterinid species with ventribiconvex shells. One species (Figure 23.1-5) is characterized by a deep, open ventral delthyrium with a vestigial homeodelthidium (Figure 23.1) and a marked change in ventral convexity towards the anterior (Figure 23.3). The identity of this species is not quite clear, although the poorly developed homeodelthidum have been considered characteristic of the genus Paterina Beecher, 1891 (Williams et al., 1998, p. 245). A closely comparable specimen from the lower Cambrian of Lab- rador identified as Paterina labradorica (Billings, 1861 ) was illustrated by Williams et al. (1998, plate 11 , figure 5 ). The ventral valve of the second species (Figure 23.6-9) is strongly and uniformly convex (Figure 23.8) and the ventral delthyrium is closed by a well-developed, convex homeodelthidium (Figure 23.6). The development of the ventral homeodelthidium is considered to be characteristic of the genus Micromitra Meek, 1873 (Williams et al., 1998, p. 245). Specimens of a broadly comparable morphology from North-East Greenland are referred to as Micromitra bella (Billings, 1872) by Skovsted and Holmer (2005).

At the present time, Laurentian species of Paterina and Micromitra are poorly known and we refrain from specific identifications. Our collections contain abundant and well-preserved specimens of both species from acid residues and in hand specimen, and a full taxonomic treatment, including investigation of relevant type material, is beyond the scope of the current presentation. The two species are treated here as Paterina sp. and Micromitra sp., respectively, based on the characteristic 


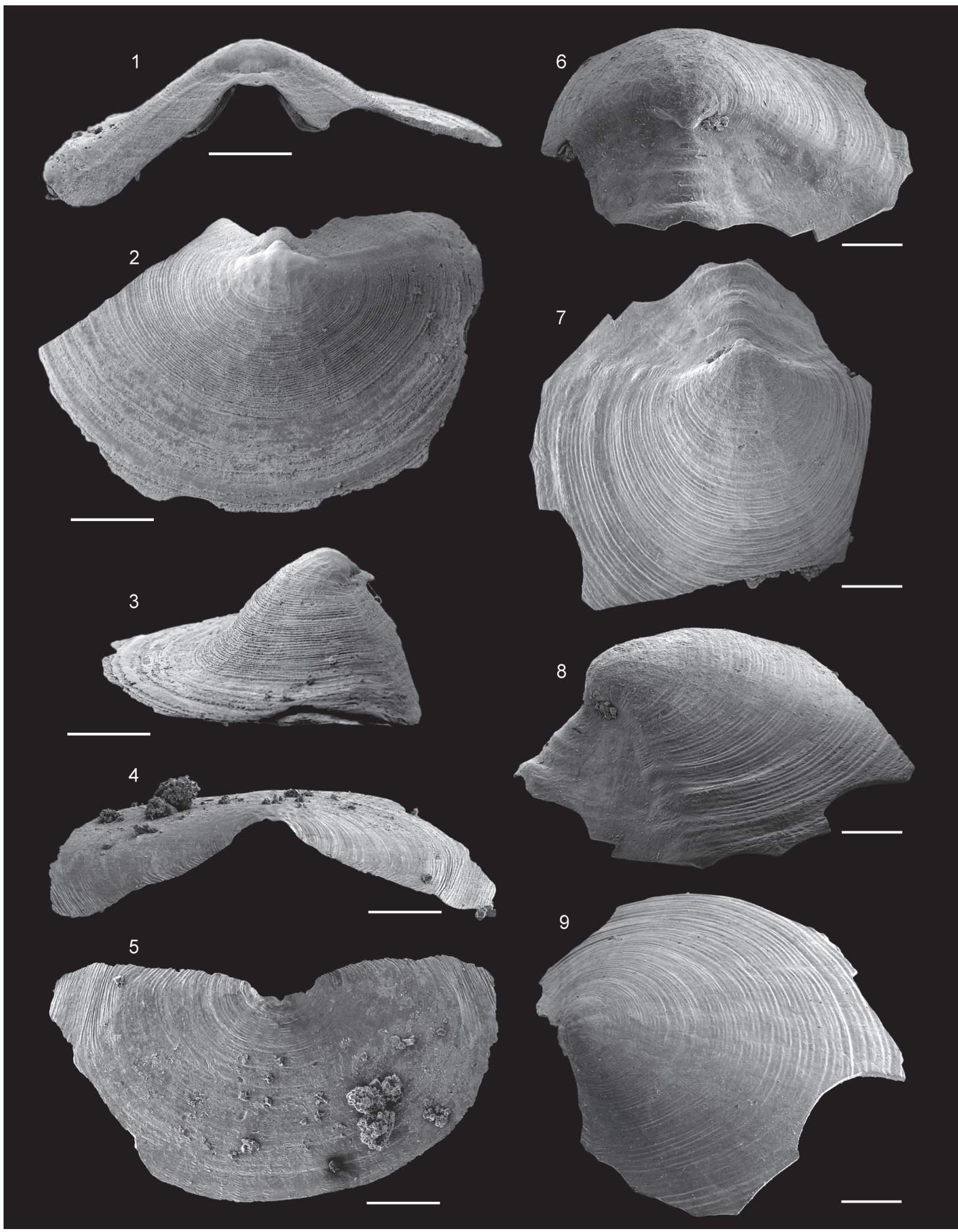

FIGURE 23. Paterinids from the Forteau Formation. 1-5, Paterina sp. 1-3, ventral valve NFM F-2555 from sample ICS1548; 1, posterior view; 2, external view; 3, lateral view. 4-5, Dorsal valve NFM F-2556 from sample LLQ3-5; 4, posterior view; 5, external view. 6-9, Micromitra sp. 6-8, Ventral valve NFM F-2557 from sample MSM-11; 6, posterior view; 7, external view; 8, lateral view. 9, Dorsal valve NFM F-2558 from sample MSM-7; oblique posterolateral view. All scalebars equal $500 \mu \mathrm{m}$. 


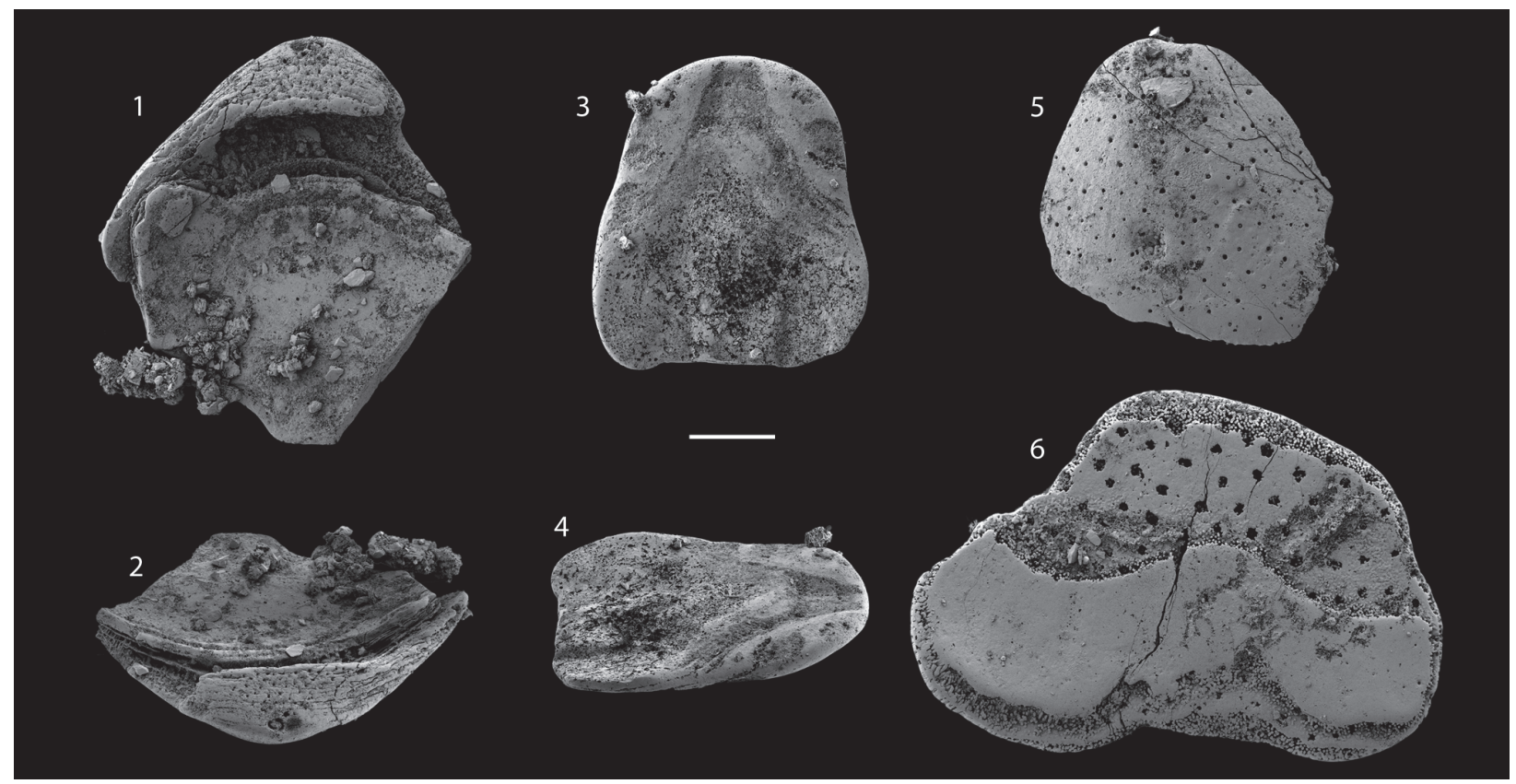

FIGURE 24. Setatella significans Skovsted, Streng, Knight and Holmer, 2010 from the Forteau Formation, The upper biostrome, L'anse au Loupe, southern Labrador. 1-2, Ventral valve NFM F-792 sample LLQ3-7; 1, internal view of posterior margin; 2, posterior view showing pseudointerarea. 3-4, Ventral valve NFM F-790, sample LLQ3-9; 3, internal view; 4, oblique lateral view. 5, Ventral valve NFM F-789, sample LLQ3-7, external view. 6, Shell fragment NFM F793, sample LLQ3-9. All scalebar equals $250 \mu \mathrm{m}$.

differences in morphology of the posterior margin of the ventral valve.

In our collections Micromitra sp. is represented by 559 ventral and 264 dorsal valves (see Appendix 1 and 2) from many samples collected from the archaeocythid reef facies to distal shelf facies. The species is very widely distributed in the study area and ranges throughout the sampled stratigraphic interval of the Forteau Formation although it is usually represented by relatively few specimens in each sample (assemblages 1-3). Paterina sp. is represented by 667 ventral, 193 dorsal valves, and a single articulated specimen (see Appendix 1 and 2) from the achaeocyathid reef facies of the Upper limestone of both southern Labrador and western Newfoundland (both part of the HST) where the species is often represented by large numbers of co-occurring specimens (assemblage 2).

LINGULIFORMEA incertae sedis

Genus SETATELLA Skovsted, Streng, Knight, and Holmer, 2010

Type species. Setatella significans Skovsted, Streng, Knight, and Holmer, 2010.

Setatella significans Skovsted, Streng, Knight, and Holmer, 2010

Figure 24
*2010 Setatella significans Skovsted, Streng, Knight, and Holmer, p. 119, figures 2-3 (includes synonymy to date).

Material. Four ventral and one dorsal valve as well as 14 shell fragments from the Forteau Formation of southern Labrador and western Newfoundland (LLQ3-5, LLQ3-7, LLQ3-9, BER-5-8, BER-5-9, R432-5-1, R432-5-2, GM07-1-1, and GM11-1-5s).

Diagnosis. See Skovsted, Streng, Knight, and Holmer, 2010 (p. 120).

Remarks. Setatella significans from North-East Greenland and Labrador is a probable member of the stem group of subphylum Linguliformea (Skovsted and Holmer, 2003; Skovsted et al., 2010). The species was recently redescribed (Skovsted et al., 2010), partly based on material from the Forteau Formation of southern Labrador. The present investigation has revealed rare new specimens of the species also from western Newfoundland (Assemblage 2; west of the Long Range Mountains), but the new material reveal no new information on the morphology or microstructure of this problematic taxon.

Distribution. Basal Devils Cove member of the Bonne Bay area, western Newfoundland, and Upper limestone of southern Labrador and western Newfoundland (Assemblage 2). Cambrian Series 
2, Stage 4 of North-East Greenland and possibly New York State.

\section{ACKNOWLEDGMENTS}

Permission from Parks Canada (GMP-20071336) to collect fossils in the Gros Morne National Park is gratefully acknowledged. The authors thank M. Streng and L.E. Holmer (both Uppsala), L.E. Popov (Cardiff), T.R. Topper (Durham), G. Ushatinskaya (Moscow), Z.-F. Zhang (Xian), G.-X. Li (Nanjing), and G.A. Brock (Sydney) for valuable discussions on Cambrian brachiopod systematics. All maps and section figures were digitally drafted by K. Morgan of the Geological Survey of Newfoundland and Labrador. Financial support from the Swedish Research Council to CBS (VR, 20065854) and UB (VR, 2006-5341) and from the Geological Survey of Newfoundland and Labrador to IK and DB made fieldwork and processing of samples possible. Constructive reviews by two anonymous reviewers and the style editor of PE are greatly acknowledged.

\section{REFERENCES}

Azmy, K., Veizer, J., Jin, J., Copper, P., and Brand, U. 2006. Paleobathymetry of a Silurian shelf based on brachiopod assemblages: an oxygen isotope test. Canadian Journal of Earth Science, 43: 281-293.

Balthasar, U. 2004. Shell structure, ontogeny, and affinities of the Lower Cambrian bivalved problematic fossil Mickwitzia muralensis Walcott, 1913. Lethaia, 37:381-400.

Balthasar, U. 2007. An Early Cambrian organophosphatic brachiopod with calcitic granules. Palaeontology, 50:1319-1325.

Balthasar, U. 2008. Mummpikia gen. nov. and the origin of calcitic-shelled brachiopods. Palaeontology, 51:263-279.

Balthasar, U. 2009. The brachiopod Eoobolus from the Early Cambrian Mural Formation (Canadian Rocky Mountains). Palaeontologische Zeitschrift, 83:407418.

Bassett, M.G., Popov, L.E., and Holmer, L.E. 1999. Organophosphatic brachiopods: patterns of biodiversification and extinction in the early Paleozoic. Geobios, 32:145-163.

Beecher, C.E. 1891. Development of the Brachiopoda, Part 1. Introduction. American Journal of Science, Series 3, 41:343-357.

Betts, M.J., Paterson, J.R., Jago, J.B., Jacquet, S.M., Skovsted, C.B., Topper, T.P., and Brock, G.A. 2016. A new lower Cambrian shelly fossil biostratigraphy for South Australia. Gondwana Research, 36:163-195.

Betts, M.J., Paterson, J.R., Jago, J.B., Jacquet, S.M., Skovsted, C.B., Topper, T.P., and Brock, G.A. 2017. Shelly fossils from the Dailyatia odyssei Biozone
(Cambrian Series 2, Stages 3-4), Arrowie Basin, South Australia. Gondwana Research, 46:240-279.

Betz, F. Jr.1939. Geology and Mineral Deposits of the Canada Bay Area, Northern Newfoundland. Newfoundland Geological Survey Bulletin, 16.

Billings, E.H. 1861. On some new or little known species of lower Silurian fossils from the Potsdam Group (Primordial zone). Palaeozoic fossils, 1, no. 1. Canadian Geological Survey, Dawson Brothers, Montreal.

Billings, E.H. 1872. On some fossils from the Primordial rocks of Newfoundland. Canadian Naturalist and Quarterly Journal of Science (New Series), 6:465480.

Bostock, H.H., Cumming, L.M., Williams, H., and Smith, W.R. 1983. Geology of the Strait of Belle Isle area, northwestern insular Newfoundland, southern Labrador and adjacent Quebec. Geological Survey of Canada, Memoir, 400.

Boucot, A.J. 1975. Evolution and extinction rate controls. Elsevier, New York.

Boyce, W.D. and Knight, I. 2016. Significant New Cambrian (Dyeran To Topazan) Trilobite Faunas of the Labrador Group, Gros Morne National Park, Western Newfoundland, Canada. p. 104, In Conliffe, J., Dickson, L., and Pereira, C. (eds.), Geological Association of Canada, Newfoundland and Labrador Section 2016 Spring Technical Meeting, Abstracts, Atlantic Geology, 52.

Brock, G.A., Engelbretsen, M.J., Jago, J.B., Kruse, P.D., Laurie, J.R., Shergold, J.H., Shi, G.R., and Sorauf, J.E. 2000. Palaeobiogeographic affinities of Australian Cambrian faunas. Association of Australasian Palaeontologists Memoir, 23:1-61.

Bruguière J.G. 1791. Tableau Encyclopédique et Méthodique des trois Règnes de la Nature : vers, coquilles, mollusques et polypes divers. Panckoucke, Paris.

Butterfield, N.J. and Harvey, T.H.P. 2012. Small carbonaceous fossils (SCFs): a new measure of early Paleozoic paleobiology. Geology, 40:71-74.

Cobbold, E.S. 1921. The Cambrian horizons of Comley (Shropshire) and their Brachiopoda, Pteropoda, Gastropoda, etc. Quarterly Journal of the Geological Society of London, 76:325-386.

Cocks, L.R.M. 1996. Lower Paleozoic brachiopod communities, p. 69-71. In Copper, P. and Jin, J. (eds.), Brachiopods. Proceedings of the Third International Brachiopod Congress. A.A. Balkema, Rotterdam, Brookfield.

Debrenne, F. and James, N.P. 1981. Reef-associated archaeocyathans from the Lower Cambrian of Labrador and Newfoundland. Palaeontology, 24:343-378.

Devaere, L., Clausen, S., Monceret, E, Vizcaïno, D., Vachard, D., and Genge, M.C. 2014. The tommotiid Kelanella and associated fauna from the early Cambrian of southern Montagne Noire (France): Implications for camenellan phylogeny. Palaeontology, 57:979-1002. 
Duméril, A.M.C. 1806. Zoologie Analytique ou Méthode Naturelle de Classification des Animaux. Allais, Paris.

Fritz, W.H. and Yochelson, E.L. 1988. The status of Salterella as a Lower Cambrian index fossil. Canadian Journal of Earth Sciences, 25:403-416.

Gorjansky, V.Yu. and Koneva, S.P. 1983. Nizhnekembrijskie Bezzamkovye Bakhiopody Khrebta Malyi Karatau (luzhnyi Kazakhstan). Akademiia Nauk SSSR, Sibirskoe otdelenie, Institut Geologii i Geofiziki (IGIG), Trudy 541:128-138. (In Russian)

Gorjansky, V.Yu. and Popov, L.E. 1985. Morfologiya, sistematicheskoe polozhenie i proiskhozhdenie bezzamkovykh brakhiopod s karbonatnoj rakovinoj. Paleontologicheskii Zhurnal, 1985(3):87-96. (In Russian)

Gravestock, D.I., Alexander, E.M., Demidenko, Yu.E., Esakova, N.V., Holmer, L.E., Jago, J.B., Lin, T.-R., Melnikova, L.M., Parkhaev, P.Yu., Rozanov, A.Yu., Ushatinskaya, G.T., Zang, W.-L., Zhegallo, E.A., and Zhuravlev, A.Yu. 2001. The Cambrian biostratigraphy of the Stansbury Basin, South Australia: Transactions of the Palaeontological Institute, 282:1-344.

Hall, J. 1847. Paleontology of New York, Volume 1. C. van Benthuysen, Albany.

Hall, J. 1859. Trilobites of the shales of the Hudson-River Group. Annual Report of the Regents of the University, on the Condition of the State Cabinet of Natural History, 12:59-62.

Hibbard, J.P., van Staal, C.R., Rankin, D.W., and Williams, H. 2006. Lithotectonic Map of the Appalachian Orogen. Geological Survey of Canada Map 2096A, 2 sheets, scale 1:1,500,000.

Hiscott, R.N., James, N.P., and Pemberton, S.G. 1984. Sedimentology and ichnology of the Lower Cambrian Bradore Formation, coastal Labrador: Fluvial to shallow marine transgressive sequence. Bulletin of Canadian Petroleum Geology, 32:11-26.

Holmer, L.E. and Caron, J.B. 2006. A soft-shelled spinose stem group brachiopod with pedicle from the Middle Cambrian Burgess Shale. Acta Zoologica, 87:273-290.

Holmer, L.E. and Popov, L.E. 2000. Lingulata, p. 30-146. In Williams, A., Brunton, C.H.C. and Carlson, S.J. (eds), Treatise on Invertebrate Paleontology: Part $H$, Brachiopoda, revised, volume 2. Geological Society of America and University of Kansas Press, Boulder.

Holmer, L.E., Popov, L.E., Koneva, S.P., and Bassett, M.G. 2001. Cambrian - Early Ordovician Brachiops from Malyi Karatau, the Western Balkhash Region, and Tien Shan, Central Asia. Special Papers in Palaentology, 65:1-180.

Holmer, L.E., Popov, L.E., Streng, M., and Miller, J. 2005. Lower Ordovician (Tremadocian) lingulate brachiopods from the House and Fillmore formations, Ibex Area, western Utah, USA. Journal of Paleontology, 79: 884-906.

Holmer, L.E., Popov, L.E., and Wrona, R. 1996. Early Cambrian lingulate brachiopods from glacial erratics of King George Island (South Shetland Islands), Antarctica. Palaeontologia Polonica, 55:37-50.

Hughes, S. 1979. Facies Anatomy of Lower Cambrian Archaeocyathid Biostrome Complex, Southern Labrador. Unpublished Masters thesis, Memorial University of Newfoundland.

Jago, J.B., Zang, W.-L., Sun, X., Brock, G.A., Paterson, J.R., and Skovsted, C.B. 2006. A review of the Cambrian stratigraphy of South Australia. Palaeoworld, 15:406-423.

Ivantzov, A.Yu., Zhuravlev, A.Yu., Leguta, A.V., Krassilov, V.A., Melnikova, L.M., and Ushatinskaya, G.T. 2005. Palaeoecology of the Early Cambrian Sinsk biota from the Siberian Platform. Palaeogeography, Palaeoclimatology, Palaeoecology, 220:69-88.

James, N.P. and Debrenne, F. 1980. First regular archaeocyaths from the northern Appalachians, Forteau Formation, western Newfoundland. Canadian Journal of Earth Sciences 17:1609-1615.

James, N.P., Knight, I., Stevens, R.K., and Barnes, C.R. 1988. Trip B1. Sedimentology and paleontology of an Early Paleozoic continental margin, western Newfoundland. Geological Association of Canada-Mineralogical Association of Canada-Canadian Society of Petroleum Geologists, Fieldtrip Guidebook.

James, N.P. and Kobluk, D.R. 1978. Lower Cambrian patch reefs and associated sediments: southern Labrador, Canada. Sedimentology 25:1-35.

James, N.P. and Stevens, R.K., 1982. Anatomy and evolution of a Lower Paleozoic continental margin, western Newfoundland. International Association of Sedimentologists Congress. Field Excursion no 2B. 1-75.

James, N.P., Stevens, R.K., Barnes, C.R., and Knight, I. 1989. Evolution of a lower Paleozoic continental-margin carbonate platform, northern Canadian Appalachians, p. 123-146. In Crevello, P.D., Wilson, J.L., and Read, J.F. (eds.), Controls on Platform and Basin Development. Society of Economic Palaeontologists and Mineralogists, Tulsa, Special Publication 44.

Knight, I. 1991. Geology of Cambro-Ordovician rocks in the Port Saunders (NTS 12l/11), Castor River (NTS $12 \mathrm{I} / 15$ ), St. John Island (NTS 12l/14), and Torrent River (NTS 12l/10) map areas. Newfoundland Department of Mines and Energy, Mineral Development Division, Report 91-4.

Knight, I. 2007. Geological studies in the Lomond (NTS $12 \mathrm{H} / 5$ ) and adjacent map areas of the eastern part of the Goose Arm Thrust Stack. Current Research. Newfoundland and Labrador Department of Natural Resources, Geological Survey, Report, 07-1:45-54.

Knight, I. 2013. The Forteau Formation, Labrador Group, in Gros Morne National Park: A preliminary reassessment of its stratigraphy and lithofacies. Current Research. Newfoundland and Labrador Department of Natural Resources, Geological Survey, Report, 131: $267-300$. 
Knight, I. and Boyce, W.D. 1987. Lower to Middle Cambrian terrigenous-carbonate rocks of Chimney Arm, Canada Bay: lithostratigraphy, preliminary biostratigraphy and regional significance. Current Research. Newfoundland Department of Mines and Energy, Mineral Development Division, Report, 87-1:359365.

Knight, I. and Boyce, W.D. 2014. Lithostratigraphy and correlation of measured sections, Middle Cambrian Hawke Bay Formation, western Port au Port Peninsula. Government of Newfoundland and Labrador, Department of Natural Resources, Geological Survey, Open File, 012B/06/0626 (with explanatory side notes).

Knight, I. and Boyce, W.D. 2015. Geological guide to the Bird Cove region, Great Northern Peninsula. Government of Newfoundland and Labrador, Department of Natural Resources, Geological Survey, Open File, NFLD/3239.

Knight, I, Boyce, W.D., Skovsted, C.B., and Balthasar, U. 2017. The Lower Cambrian Forteau Formation, southern Labrador and Great Northern Peninsula, western Newfoundland: Lithostratigraphy, trilobites, and depositional setting. Government of Newfoundland and Labrador, Department of Natural Resources, Geological Survey, St. John's, Occasional Papers 2017-01, 72 pages.

Kobluk, D.R. and James, N.P. 1979. Cavity-dwelling organisms in Lower Cambrian patch reefs from southern Labrador. Lethaia, 12:193-218.

Koneva, S.P. 1986. Novoe semeistvo kembriiskikh bezzamkovykh brakhiopod. Paleontologicheskii Zhurnal, 1986(1):49-55. (In Russian)

Kouchinsky, A., Bengtson, S., Runnegar, B., Skovsted, C., Steiner, M., and Vendrasco, M. 2012. Chronology of early Cambrian biomineralization. Geological Magazine, 149:221-251.

Kuhn, O. 1949. Lehrbuch der Paläozoologie. E. Schweizerbart, Stuttgart.

Landing, E. and Bartowski, K.E. 1996. Oldest shelly fossils from the Taconic allochthon and late Early Cambrian sea-levels in Eastern Laurentia. Journal of Paleontology, 70:741-761.

Landing, E., Geyer, G., and Bartowski, K.E. 2002. Latest Early Cambrian small shelly fossils, trilobites, and Hatch Hill dysaerobic interval on the Quebec continental slope. Journal of Paleontology, 76:287-305.

Larsson, C., Skovsted, C.B., Brock, G.A., Balthasar, U., Topper, T.P., and Holmer, L.E. 2014. Paterimitra pyramidalis from South Australia: scleritome, shell structure and evolution of a lower Cambrian stem group brachiopod. Palaeontology, 57:417-446.

Li, G.X. and Holmer, L.E. 2004. Early Cambrian lingulate brachiopods from the Shaanxi Province, China. GFF, 126:193-211.

Lochman, C. 1956. Stratigraphy, paleontology and paleogeography of the Elliptocephala asaphoides strata in Cambridge and Hoosick Quadrangles, New York.
Bulletin of the Geological Society of America, 67:1331-1396.

Long, D.G.F. and Yip, S.S. 2009. The early Cambrian Bradore Formation of southeastern Labrador and adjacent parts of Quebec: Architecture and genesis of clastic strata on an early Paleozoic wave-swept shallow marine shelf. Sedimentary Geology, 215:5069.

Maloof, A.C., Porter, S.M., Moore, J.L., Dudas, F.Ö., Bowring, S.A., Higgins, J. A., Fike, D.A., and Eddy, M.P. 2010. The earliest Cambrian record of animals and ocean geochemical change. Geological Society of America Bulletin, 122:1731-1774.

Matthew, G.F. 1889. On the classification of the Cambrian rocks in Acadia. Canadian Record of Science, 3:303-315.

Matthew, G.F. 1891. Illustrations of the fauna of the St. John Group, No. 5. Royal Society of Canada, Transactions (Series 1, Section 4), 8:123-166.

Matthew, G.F. 1899. Preliminary notice of the Etcheminian fauna of Cape Breton. New Brunswick Natural History Society, Bulletin, 4:198-208.

Matthew, G.F. 1901. Acrothyra, a new genus of Echeminian brachiopods. New Brunswick Natural History Society, Bulletin, 4:303-304.

Matthew, G.F. 1902. Notes on Cambrian faunas. Royal Society of Canada, Transactions (Series 2, Section 4), 18:93-112.

McBride, D.J. 1976. Outer shelf communities and trophic groups in the Upper Cambrian of the Great Basin. Brigham Young University Geology Studies, 23:139152.

Meek, F.B. 1873. Preliminary palaeontological report. Annual Report of the United States Geological Survey of Montana, Idaho, Wyoming, and Utah, 6:429518.

Menke, C.T. 1828. Synopsis methodica molluscorum generum omnium et specierum earum quae in Museo Menkeano adservantur. G. Uslar, Pyrmonti.

Mergl, M. 2002. Linguliformean and craniiformean brachiopods of the Ordovician (Třenice to Dobrotivá Formations) of the Barrandian, Bohemia. Acta Musei Nationalis Pragae, Series B 58:1-82.

Palmer, A.R. 1969. Cambrian trilobite distribution in North America and their bearing on Cambrian paleogeography of Newfoundland, p. 139-144. In Kay, M. (ed.), North Atlantic Geology and Continental Drift. American Association of Petroleum Geologists, Memoir 12.

Paterson, J.R., Skovsted, C.B., Brock, G.A., and Jago, J.B. 2007. An Early Cambrian faunule from the Koolywurtie Limestone Member (Parara Limestone), Yorke Peninsula, South Australia and its biostratigraphic significance. Memoir of the Association of Australasian Palaeontologists, 34:131-146.

Peel, J.S., Streng, M., Geyer, G., Kouchinsky, A., and Skovsted, C.B. 2016. Ovatoryctocara granulata assemblage (Cambrian Series 2-Series 3 boundary) 
of Løndal, North Greenland. Memoir of the Association of Australasian Palaeontologists, 49:241-282.

Pelman, J.L. 1977. Ranne- i srednekembriyskie bezzamkovye brakhiopody Sibirskoy platformy. Trudy Instituta Gologii i Geofiziki Sibirskogo otdelenija AN SSSR, 36:1-168. (In Russian)

Pelman, J.L. and Pereladov, V.S. 1986. Stratigraphy and brachiopods of the Lower - Middle Cambrian of the Arga-Sala River (Southern Anabar area), p. 119-153. In Zhuravleva, I.T. (ed.), Cambrian biostratigraphy and palaeontology of Northern Asia. Trudy, Institut geologii i geofiziki, 669. (In Russian).

Pelman, Yu.L., Aksarina, N.A., Koneva, N.P., Popov, L.E. Sobolev, L.P. and Ushatinskaya, G.T. 1992. Drevneyshie brachiopody territorii SevernoyEvrazii. OIGGiM SO RAN, Novosibirsk. (In Russian)

Pemberton, S.G. and Kobluk, D.R. 1978. Oldest known brachiopod burrow: the Lower Cambrian of Labrador. Canadian Journal of Earth Sciences, 15:1385-1389.

Petterson Stolk, S., Holmer, L.E. and Caron, J.B. 2009. First record of the brachiopod Lingulella waptaensis with pedicle from the Middle Cambrian Burgess Shale. Acta Zoologica, 91:150-162.

Popov, L.E., Holmer, L.E., Hughes, N.C., Ghobadi Pour, M. \& Myrow, P.M. 2015. Himalayan Cambrian brachiopods. Papers in Palaeontology, 1: 345-399.

Poulsen, C. 1927. The Cambrian, Ozarkian and Canadian faunas of northwest Greenland. Meddelelser om Grønland, 70:233-343.

Poulsen, C. 1932. The Lower Cambrian faunas of East Greenland. Meddelelser om Grønland, 87:1-66.

Resser, C.E. 1937. Elkanah Billings' Lower Cambrian trilobites and associated species. Journal of Paleontology, 11:43-54.

Rong, J.Y., 1974. Cambrian brachiopods, p. 113-114. In Nanjing Institute of Geology. (ed.), Handbook of Palaeontology and Stratigraphy of Southwest China. Science Press, Beijing (In Chinese).

Rowell, A.J. 1965. Inarticulata, p. H359-H361. In Moore, R.C., (ed.), Treatise on Invertebrate Paleontology. Part H, Brachiopoda. The Geological Society of America, New York, and the University of Kansas Press, Lawrence.

Rowell, A.J. 1966. Revision of some Cambrian and Ordovician inarticulate brachiopods. The University of Kansas, Paleontological Contributions, 7:1-36.

Rowell, A.J. 1977. Early Cambrian brachiopods from the southwestern Great Basin of California and Nevada. Journal of Paleontology, 51:68-85.

Rowell, A.J. 1980. Inarticulate brachiopods of the Lower and Middle Cambrian Pioche Shale of the Pioche District, Nevada. University of Kansas Paleontological Contributions, 98:1-26.

Rozanov, A.Yu., Parkhaev, P.Yu., Demidenko, Yu.E., Karlova, G.A., Korovnikov, I.V., Shabanov, Yu.Ya, Ivantzov, A.Yu., Luchinina, V.A., Malakhovskaya, Ya.E., Melnikova, L.M., Naimark, E.B., Ponomarenko, A.G., Skorlotova, N.A., Sundukov, V.M., Tokarev, D.A., Ushatinskaya, G.T., and Kipriyznova,
L.D. 2010. Iskopaemye Stratotipov Yarusov Nizhnego Kembriya. PIN RAN, Moskva. (In Russian)

Schindewolf, O.H. 1955. Über einige kambrische Guttung inartikulater Brachiopoden. Neues Jahrbuch für Mineralogie, Geologie und Palaeontologie, 12:538557.

Schmidt, F. 1888. Über eine neuendeckte untercambrische Fauna in Estland. Académie Impériale des Sciences, St Petersbourg, Mémoires (Series 7), $36: 1-27$.

Schuchert, C. 1893. Classification of the Brachiopoda. American Geologist, 11:141-167.

Schuchert, C. and Dunbar, C.O. 1934. Stratigraphy of western Newfoundland. Memoir of the Geological Society of America 1:1-123.

Skinner, E.S. 2005. Taphonomy and depositional circumstances of exceptionally preserved fossils from the Kinzers Formation (Cambrian), southeastern Pennsylvania. Palaeogeography, Palaeoclimatology, Palaeoecology, 220:167-192.

Skovsted, C.B. 2003. Unusually preserved Salterella from the Lower Cambrian Forteau Formation of Newfoundland. GFF, 125:17-22.

Skovsted, C.B. 2004. Mollusc fauna of the Early Cambrian Bastion Formation of North-East Greenland. Bulletin of the Geological Society of Denmark 51:1137.

Skovsted, C.B. 2006. Small shelly fauna from the late Early Cambrian Bastion and Ella Island Formations, North-East Greenland. Journal of Paleontology, 80:1087-1112.

Skovsted, C.B., Brock, G.A., Paterson, J.R., Holmer, L.E., and Budd, G.E. 2008. The scleritome of Eccentrotheca from the Lower Cambrian of South Australia: lophophorate affinities and implications for tommotiid phylogeny. Geology, 36:171-174.

Skovsted, C.B., Brock, G.A., Topper, T.P., Paterson, J.R. and Holmer, L.E. 2011. Scleritome construction, biofacies, biostratigraphy and systematics of the tommotiid Eccentrotheca helenia sp. nov. from the early Cambrian of South Australia. Palaeontology, 54:253286.

Skovsted, C.B., Clausen, S., Álvaro, J.J., and Ponlevé, D. 2014a. Tommotiids from the early Cambrian (Series 2, Stage 3) of Morocco and the evolution of the tannuolinid scleritome and setigerous shell structures in stem group brachiopods. Palaeontology 57:171-192.

Skovsted, C.B. and Holmer, L.E. 2003. The Early Cambrian stem group brachiopod Mickwitzia from Northeast Greenland. Acta Palaeontologica Polonica, 48:11-30.

Skovsted, C.B. and Holmer, L.E. 2005. Early Cambrian brachiopods from North-East Greenland. Palaeontology, 48:325-345.

Skovsted, C.B. and Holmer, L.E. 2006. The Lower Cambrian brachiopod Kyrshabaktella and associated shelly fossils from the Harkless Formation, southern Nevada. GFF, 128:327-337. 
Skovsted, C.B., Holmer, L.E., Larsson, C.M., Högström, A.E.S., Brock, G.A., Topper, T.P., Balthasar, U, Petterson Stolk, S., and Paterson, J.R. 2009. The scleritome of Paterimitra: an Early Cambrian stem group brachiopod from South Australia. Proceedings of the Royal Society of London B, 276:1651-1656.

Skovsted, C.B., Kouchinsky, A, Bengtson, S., and Holmer, L.E. 2014b. The problematic Early Cambrian fossil Tumulduria incomperta represents the detached ventral interarea of a paterinid brachiopod. Acta Palaeontologica Polonica, 59:359-365.

Skovsted, C.B. and Peel, J.S. 2007. Small shelly fossils from the argillaceous facies of the Lower Cambrian Forteau Formation of Western Newfoundland. Acta Palaeontologica Polonica, 52:729-748.

Skovsted, C.B. and Peel, J.S. 2010. Early Cambrian brachiopods and other shelly fossils from the basal Kinzers Formation of Pennsylvania. Journal of Paleontology, 84:754-762.

Skovsted, C.B., Streng, M., Knight, I. and Holmer, L.E. 2010. Setatella significans, a new name for mickwitziid stem group brachiopods from the lower Cambrian of Greenland and Labrador. GFF, 132:117-122.

Skovsted, C.B., Ushatinskaya, G., Holmer, L.E., Popov, L.E., and Kouchinsky, A. 2015. Taxonomy, morphology, shell structure and early ontogeny of Pelmanotreta nom. nov. from the lower Cambrian of Siberia. GFF, 137:1-8.

Spencer, L.M. 1980. Paleoecology of a Lower Cambrian archaeocyathid interreef fauna from Southern Labrador. Unpublished MS thesis, State University of New York at Stony Brook.

Stewart, J.H. 1970. Upper Precambrian and Lower Cambrian strata in the southern Great Basin, California and Nevada. U.S. Geological Survey Professional Paper, 620:1-206.

Strand, T. 1929. The Cambrian beds of the Mjøsen district in Norway. Norsk Geologisk Tidsskrift, 10:308365.

Streng, M., Holmer, L.E., Popov, L.E., and Budd, G.E. 2008. Columnar shell structures in early linguloid brachiopods - new data from the Middle Cambrian of Sweden. Earth and Environmental Science Transactions of the Royal Society of Edinburgh, 98:221-232.

Topper, T.P., Holmer, L.E., and Caron, J.B. 2014. Brachiopods hitching a ride: an early case of commensalism in the middle Cambrian Burgess Shale. Scientific Reports 4:6704

Topper, T.P., Strotz, L.C., Holmer, L.E., Zhang, Z.F., Tait, N.N., and Caron, J.B. 2015. Competition and mimicry: the curious case of chaetae in brachiopods from the middle Cambrian Burgess Shale. BMC Evolutionary Biology, 15:42.

Ushatinskaya, G.T. 2001. Brachiopods, p. 350-369. In Zhuravlev, A.Yu. and Riding, R. (eds.), Ecology of the Cambrian Radiation. Columbia University Press, New York.
Ushatinskaya, G.T. 2008. Origin and Dispersal of the Earliest Brachiopods. Paleontological Journal, 42:776-791.

Ushatinskaya, G.T. and Korovnikov, I.V. 2014. Revision of the Early-Middle Cambrian Lingulida (Brachiopoda) from the Siberian Platform. Paleontological Journal, 48:26-40.

Ushatinskaya, G.T. and Korovnikov, I.V. 2016. Revision of the Superfamily Acrotheloidea (Brachiopoda, Class Linguliformea, Order Lingulida) from the Lower and Middle Cambrian of the Siberian Platform. Paleontological Journal, 50:450-462.

Voronova, L.G., Drosdova, N.A., Esakova, N.V., Zhegallo, E.A., Zhuravlev, A.YU., Rozanov, A.YU., Sayutina, T.A., and Ushatinskaya G.T. 1987. Lower Cambrian fossils of the Mackenzie Mountains (Canada). Trudy Paleontologicheskyi Institut, 224:1-88. (In Russian)

Waagen, W. 1885. Salt Range fossils, vol. 1, Part 4. Productus Limestone fossils, Brachiopoda. Memoirs of the Geological Survey of india, Palaeontologia Indica (Series 13, Fasc. 5), 729-770.

Walcott, C.D. 1887. Fauna of the 'upper Taconic' of Emmons in Washington County, New York. American Journal of Science, Third Series, 34:187-199.

Walcott, C.D. 1902. Cambrian Brachiopoda: Acrotreta; Linnarssonella; Obolus; with descriptions of new species. United States National Museum, Proceedings, 25:577-612.

Walcott, C.D. 1905. Cambrian Brachiopoda with descriptions of new genera and species. United States National Museum, Proceedings, 25:669-695.

Walcott, C.D. 1910. Olenellus and other genera of the Mesonacidae. Smithsonian Miscellaneous Collections, 53:231-422.

Walcott, C.D. 1912. Cambrian Brachiopoda. Monograph of the United States Geological Survey, 51 (two volumes), 872 pp., 104 pls.

Walcott, C.D. and Schuchert, C. 1908. Family Obolellidae, p. 145. In Walcott, C.D. (ed.), Cambrian geology and paleontology - Number 3: Cambrian Brachiopoda, description of new genera and species; Number 4: classification and terminology of the Cambrian Brachiopoda. Smithsonian Miscellaneous Collections, 53:53-165.

Wang, H.Z., Zhang, Z.F., Holmer, L.E., Holmer, E., Hu, S.X., Wang, X.R., and Li, G.X. 2012. Peduncular attached secondary tiering acrotretoid brachiopods from the Chengjiang fauna: Implications for the ecological expansion of brachiopods during the Cambrian explosion. Palaeogeography Palaeoclimatology Palaeoecology, 323:60-67.

Wanner, A. 1901. A new species of Olenellus from the Lower Cambrian of York County, Pennsylvania. Proceedings of the Washington Academy of Sciences, 3:267-272.

Webster, M. 2011. Trilobite biostratigraphy and sequence stratigraphy of the Upper Dyeran (traditional Laurentian "Lower Cambrian") in the southern 
Great Basin, U.S.A., p. 121-154. In Hollingsworth, J.S., Sundberg, F.A., and Foster, J.R. (eds.), Cambrian Stratigraphy and Paleontology of Northern Arizona and Southern Nevada. Museum of Northern Arizona Bulletin, 67.

Williams, A., Carlson, S.J., Brunton, C.H.C., Holmer, L.E., and Popov, L.E. 1996. A supra-ordinal classification of the Brachiopoda. Philosophical Transactions of the Royal Society of London (Series B), 351:1171-1193.

Williams, A., Popov, L.E., Holmer, L.E., and Cusack, M. 1998. The diversity and phylogeny of the paterinate brachiopods. Palaeontology, 41:221-262.

Williams, H. 1979. Appalachian orogen in Canada. Canadian Journal of Earth Sciences, 16:792-807.

Yochelson, E.L. 1977. Agmata, A proposed extinct phylum of Early Cambrian age. Journal of Paleontology, 51:437-454.

Ziegler, A.M. 1965. Silurian marine communities and their environmental significance. Nature, 207:270272.

Ziegler, A.M., Cocks, L.R.M., and Bambach, R.K. 1968. The composition and structure of lower Silurian marine communities. Lethaia, 1:1-27.

Zhang, Z.F., Han, J., Wang, Y., Emig, C.C., and Shu, D.G. 2010. Epibionts on the lingulate brachiopod Diandongia from the Early Cambrian Chengjiang Lagerstätte, South China. Proceedings of the Royal Society of London B, 277:175-181.
Zhang, Z.F., Han, J., Zhang, X.L., Liu, J.N., and Shu, D.G. 2003. Pediculate brachiopod Diandongia pista from the Lower Cambrian of Southern China. Acta Geologica Sinica, 77:288-293.

Zhang, Z.F., Han, J., Zhang, X.L., Liu, J.N., and Shu, D.G. 2004. Soft-tissue preservation in the Lower Cambrian linguloid brachiopod from South China. Acta Palaeontologica Polonica, 49:259-266.

Zhang, Z.F., Holmer, L.E., Popov, L., and Shu, D.G., 2011. An Obolellate Brachiopod with Soft-Part Preservation from the Early Cambrian Chengjiang Fauna of China. Journal of Paleontology, 85:460-463.

Zhang, Z.F., Li, G.X., Emig, C.C., Han, J., Holmer, L.E., and Shu, D.G. 2009. Architecture and function of the lophophore in the problematic brachiopod Heliomedusa orienta (Early Cambrian, South China). Geobios, 42:649-661.

Zhang, Z.F., Robson, S.P., Emig, C.C., and Shu, D.G. 2008. Early Cambrian radiation of brachiopods: $A$ perspective from South China. Gondwana Research, 14:241-254.

Zhang, Z.F., Shu, D.G., Emig, C., Zhang, X.L., Han, J., Liu, J.N., Li, Y., and Guo, J.F. 2007. Rhynchonelliformean brachiopods with soft-tissue preservation from the early Cambrian Chengjiang Lagerstätte of South China. Palaeontology, 50:1391-1402.

Zhang, Z.F., Zhang, Z.L., Li, G.X., and Holmer, L.E. 2016. The Cambrian brachiopod fauna from the firsttrilobite age Shuijingtuo Formation in the Three Gorges area of China. Palaeoworld, 25:333-355. 


\section{APPENDIX 1.}

Table listing all identified brachiopod specimens from all investigated samples collected by the authors from the Forteau Formation of southern Labrador and western Newfoundland (both sections on Great Northern Penninsula and Gros Morne National Park) with locality name and stratigraphical unit indicated. For each sample all brachiopod specimens were counted where the posterior margin is preserved and identification to species and valve type was possible ( $v=$ ventral valves; $d=$ dorsal valves; $a=$ articulated specimens. For Setatella significance Skovsted, Streng, Knight and Holmer, 2010 valve fragments were also counted. The total number of specimens for each species and valve type is indicated at the bottom of the table.

Available as an Excel spread sheet at palaeo-electronica.org/content/2017/2048-brachiopodsof-the-forteau-formation.

\section{APPENDIX 2.}

Table listing all identified brachiopod specimens from all investigated samples from the Forteau Formation of southern Labrador and western Newfoundland derived from the Institute of Cambrian Studies (ICS; Boulder Colorado and University of Chicago, Michigan) and Professor John S. Peel (JSP; Uppsala) as well as samples collected by the authors from float and/or poorly constrained sections west of Forteau (F-1) and in the vicinity of Fox Cove (FCX) in southern Labrador with approximate locality details and stratigraphical units indicated. For each sample all brachiopod specimens were counted where the posterior margin is preserved and identification to species and valve type was possible $(v=$ ventral valves; $d=$ dorsal valves; $a=$ articulated specimens. The total number of specimens for each species and valve type is indicated at the bottom of the table.

Available as an Excel spread sheet at palaeo-electronica.org/content/2017/2048-brachiopodsof-the-forteau-formation. 